Western University

Scholarship@Western

Digitized Theses

Digitized Special Collections

1988

\title{
Ultrastructure And Atpase Nature Of Polar Membrane In Campylobacter Jejuni
}

Frances Marguerite Brock

Follow this and additional works at: https://ir.lib.uwo.ca/digitizedtheses

\section{Recommended Citation}

Brock, Frances Marguerite, "Ultrastructure And Atpase Nature Of Polar Membrane In Campylobacter Jejuni" (1988). Digitized Theses. 1691.

https://ir.lib.uwo.ca/digitizedtheses/1691

This Dissertation is brought to you for free and open access by the Digitized Special Collections at Scholarship@Western. It has been accepted for inclusion in Digitized Theses by an authorized administrator of Scholarship@Western. For more information, please contact tadam@uwo.ca, wlswadmin@uwo.ca. 


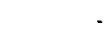

The quality of this microlorm is heavily dependent upon the quality of the original thesis submitted for microfilming Every effort has been made to ensure the highest quality of reproduction possible

If pages are missing, contact the university which granted the degree.

Some pages may have indistinct print especially if the original pages were typed with a poor typewriter ribbon or if the university sent us an intertor photocopy

Previously-copyrighted materials (journal anticles, published tests, etc ) are not filmed.

Reproduction in full or in part of this microtorm is governed by the Canadian Copyright Act, R S C 1970. C C.30

$$
\because 3
$$

La qualite de celle microtorme deperad grandeme'nt de. his qualite detla inese soumise au microtilniage Nous avols. lout lant pour assurer une qualite superleure de reproduc iton

Sil manque des panes veuitez communiquer avec luniversite qui a contere le grade

La quahte dimpression de cenaines pages pexil lussiet a desirer. sunout si le's pages originales ont éle daclylour.l phiees a l'arde d'un ruban use ou si l'universile? rows a y.ll parvenir une pholocopie de qualite inlerieure

Les documents qui font depa lobjet diun droit diauteur (articles de revue. lests publies titc) ne: soml pis microfilmes

La reproduction, mème parfielle dis cille microtorm, "'il soumise a la Lo canadiengie: sur lez droil didestrur 'ific. 1970. C C.30 

Pernission has been granted to the National Ilbrary of Canada to nicrofiln this thesis and to lend or sell coples of the fild.

The author (copyright owner) has reserved other publication rights, and neither the theste nor extensive extracts from it nay be printed or otherwise reproduced without his/her written peralselon. i'autgrisation a eté accorabe a lataibliotheque nationale du Canada de nicrofileer cette thèse et de prêter ou de vendre des exemplaires du f11: .

L'auteur (titulaire du drolt d'auteur) se reserve les autres drolts de publication; ni la these ni de longs extralts de celle-ci ne dolvent etre Imprimes'ou autrement reprodults sans aon autorisation scrite.

$$
\text { I SBN } \quad 0-315-40759-x
$$

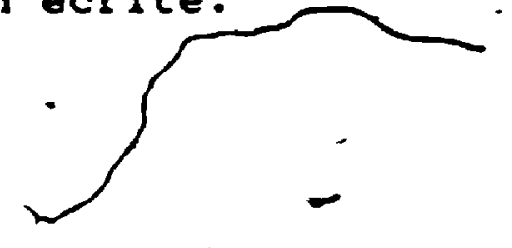



Abstract

The ultrastructure of polar membrane in Campylebacter jejuni was examined and was shown to fine the cytoplasmic membrane at the poles of the cell like an internal cylindrical cap. This was not found to be the case in -Aquaspixiblum serpens MW5, where the polar membrane was found in patches, lining the cytoplasmic membrane near the Flagellar tufts. Polar nembrame in $\subseteq$. jeiuni. was found at the site of septum formation, although this was not a consistenteresuzt.

The component parts of polar membrane (stalks and knobsl were foúnd to be consistent with previous reports of this strusture, al thourh their dimensions fstalks, $2-3 \mathrm{~nm}$ in diameter; and knobs, 5-6 nm in diameter were smaller thian those described for Ectothiorhbdespira mobjlds (stalks 3-4 $\mathrm{nm}$ in diameter, and knobs, 8-9 $\mathrm{nm}$ in diameter).

- The association of polar membrane with the flagellar: basal complex was examined and it was found that this structure encroacheis on the lateral mareins of the basad complex to varying degrees, but was never fipund to covsr the. area where the M ríns, was located. $:^{\prime \prime}$ An area containlug fewer ribosones than the fest of 
cytoplasm was found in the location of the polar membrane in - C jejuni and A. serpens MW5. C. jejuni was found to have a densely staining sphbrical inclusion body, probably consisting of phosphate moieties. in the cytoplasm beneath the polar membrane structure.

- Polar membrane in $\mathcal{c}$. Diunj has been visualized on. mepbrane vesicles. It is composed of dough-nut shaped paxticles 5-6 $\mathrm{nm}$ in diameter. arranged in an hexagonal afray. This structure was stäbilized on the membranes by a Kigh ionic strength kuffer in the presence of

\section{res} 2-mercaptoethanol.

- C: jejuni sheds its flagella and varying proportions of the poles of the cell late in the growth cycle, resulting - in the production of very small flagollated straigtires 1.1 to 0.3 um in diameter. Electron microscopy revoalod that these structures were minicells possessing.outer membrane. Fy.tollasmic membrane, ilagellar basal complex, and polar mombrine; nucleoplasms were not seen. The initial event in 'the formation of these minicells' involved a constriction of

$\because$ : the crtoplasmic membrane, segregating the polar regions of the cell. The peptidoglycan layer of the cell wall was not - visible, but was presumed to lyse at the separation site of : minicell formation, land to reform or remain intact along.tha 
main length of the cell because the rods did not spheroplast. Finally, rupture and resealing of the outer membrane component of the wall resulted in the release of iulfy enclosed minicells and nontilagellated rods.

- Histochemical staining of whole cells of $\ddot{C}$. jejuni. indicated localized $\mathrm{Mg}^{2}+$-ATPase activity at the poles of the cells. Ca2+-ATPase activity was randomly distributed throughout the cell. Histochemical staining tor Mgí-ATFase and lä,+-ATPase activity was performed in Escherichia coli K12. Bacilius cereus, Micrococous luteus, Deinococcus radiodurans, and A- serpens MW5 for comparișon with that - found in C. jeiuni. A. serpens MW5, which also possessed polar membrane, showed localized.Ca'-ATPase activity at the A poles of the cells and Mgat-ATPase activity randomly

- distributed throughout the cell.

An ATPase with distinctive properties was isolated and puritied from $\dot{S}$. jejuni giving a specific activizy of approximately $0: 3$ units/mg of protein. Electron microscopy showed dough-nut shaped particles 5-6 nm in diameter. Non-dissociating and sodium.dodecyl sulfate polyacrylamide gel electrophoresis of the purified enzyme revealed. respectively, a single band with ATPase activity and a molecular weight of ca. 75,000 daltons. The enzyme was lold labile and activity was abolished by trypsin. 
Dicylohexylcarboditimide inhibited the membrane-bound form of the enzyme, but did not inhibit the soluble form Uligomycin had no inhibitory activity on either form of the onzyme. The enzyme specifically hydrolysed ATP, other nucleotide substrates were not degraded. The enzyme was activated by $\mathrm{Mg}^{2}+$ and inhibited by $\mathrm{Ca}^{2}+$, other ions had no etfoct on activity.

Antibodies prepared to this enzyme bound to' the polar regions of whole cells of $\mathfrak{Q}$. jejuni as shown by protein. A-colloidal gold immunoelectron microscopy. The antibodies to this ATPase cross reacted (shown by Western blotting) with four proteins from a whole cell extract of this organism, two proteins in A. serpens MW5, and three proteins for E. colik12. They did not cross react with any proteias from Spirillum volutans, Methanococccus voltag. Vibrio cholerae. or rat liver mitochondria. Antibodies rajserd against the F1-ATPase of $\mathbf{E}$. celi $\mathrm{K} 12$ cross reacted with six proteins in a whole cell extraot of this organism, and one protein species.in each of the whole cell extracts of $\underline{V}$ cholerae, A. serpens MW5. S. velutans, and rat liver mitochondria. These antibodies did not recognize any whole cell proteins firom either $\underline{c}$. Lejuni, or $\dot{y}$ voltae.

These results along with the ATPase activity localized by Histochemical staining indicate that polar membrane functions as an ATPase. 


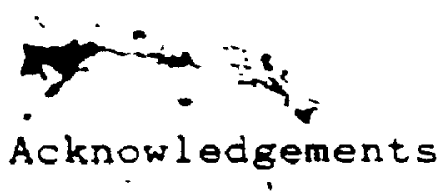

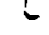

The author wisbes to thank Dr. R.G.E. Murray for his scientific, input, support, patieice, and long-suffering throughout the course.of this work.

The technical assistence of Mickey Hall and Dianne Moyles was also greatly appreciated.

As well, the author is indepted to zobeeda (2o) Hosein, and Marion Kist for their scientific and social support during the ygars at Western.

Finally, and perhaps, most important, the author wishes to thank her Mother and Father for their. undying support (both moral and financial) and, for their prayers.

The author was financially supported by Oritario Graduate Scholarships and the Medical Research Council of Canada.

This work was financed by the Medical Research Louncil of Canada.

vii 


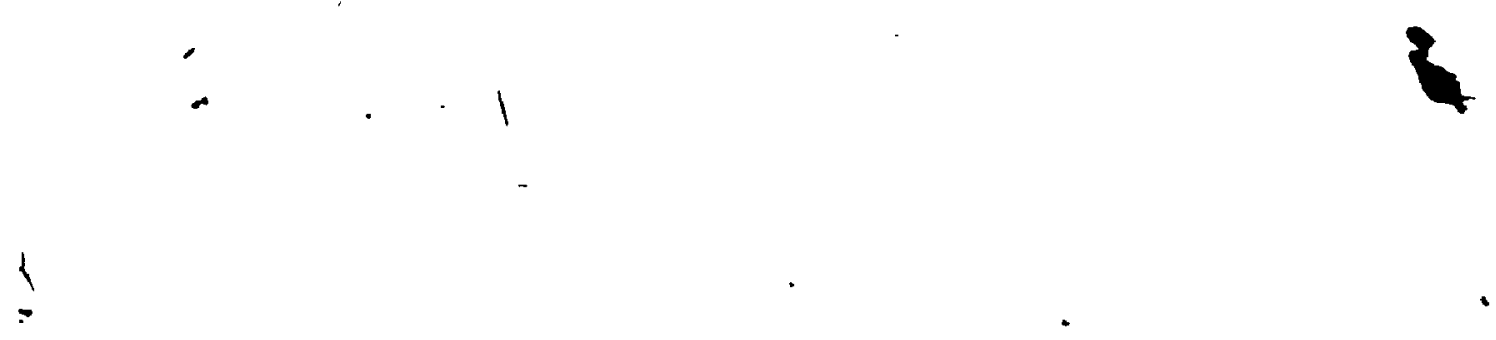

"For now we see in a mirror dimly, but then face to face, now I. know in part, but then I shall know fully just as. I. also have been fully known." I Corinthians 13:12. 
CERTIFICATE OF EXAMINATION................... i

ABSTRACT ............................. . . . .

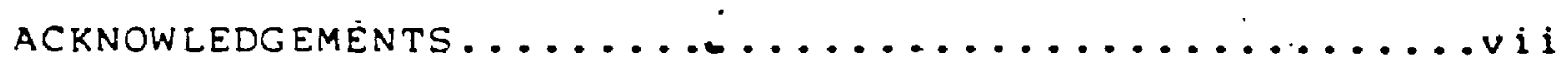

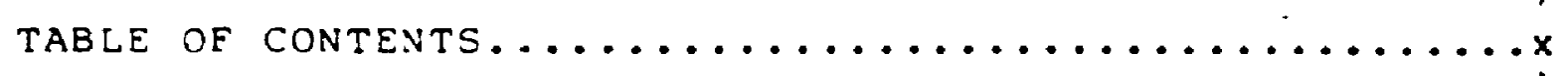

LIST $D F$ TABLES...........................

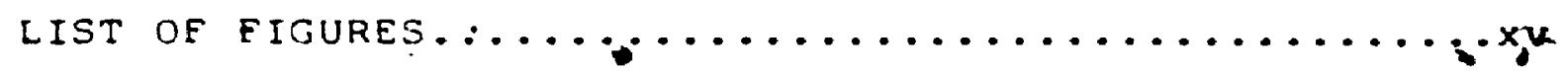

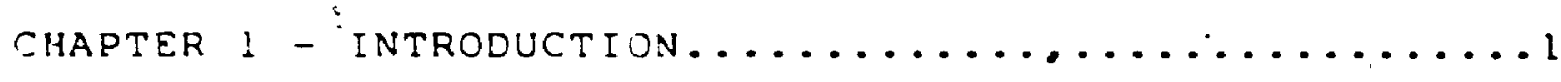

1.1. Campylobacter jejunl: Description

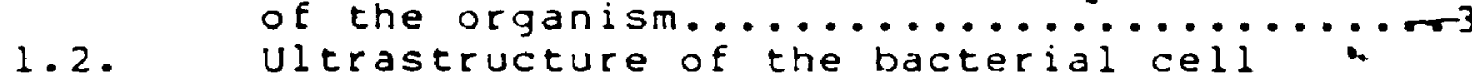

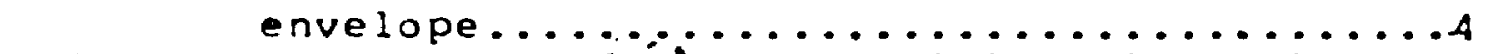

1.3. Components of the bacterial cell envelope..5

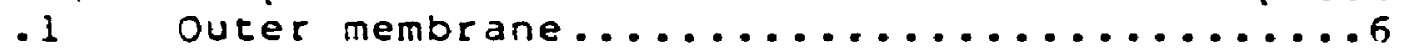

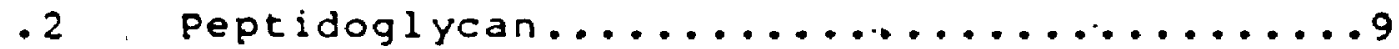

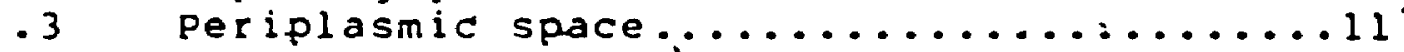

.4 Cytoplasmic membrane..................11

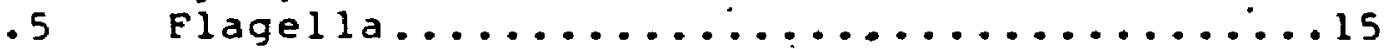

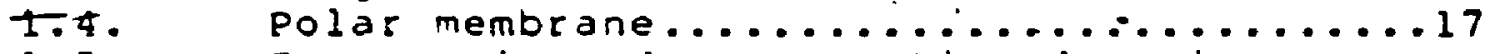

1.5. Eucaryotic and procaryotic adenosine.

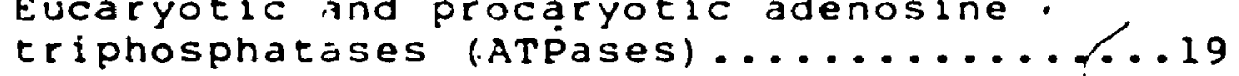

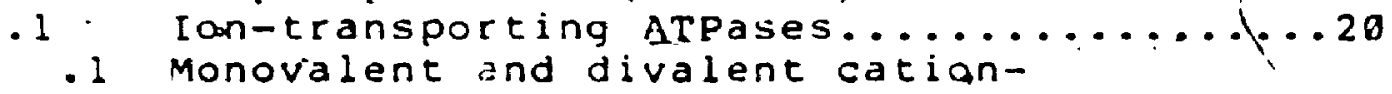

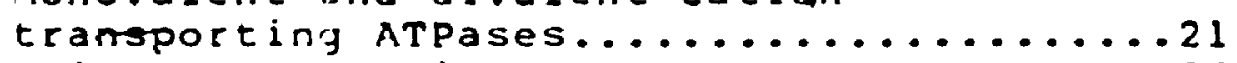

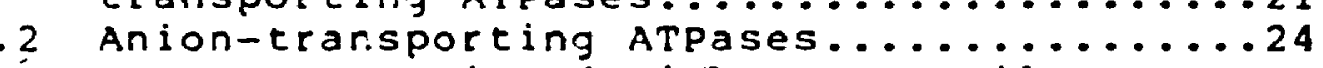

.2 ATpases associated with contractile

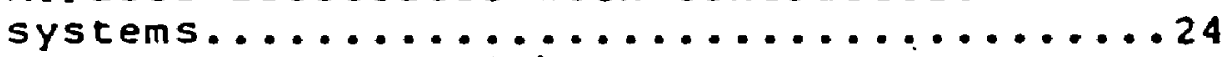

Proton-Translocating Arpases.............24

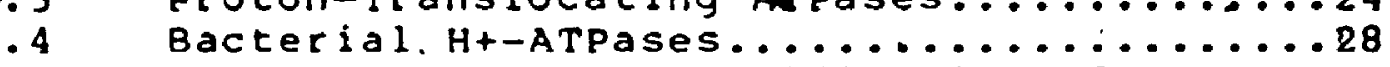

.5 Solubilization and. purification of the.

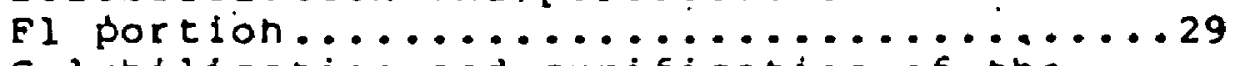

. 6 Solubilization and purification of the

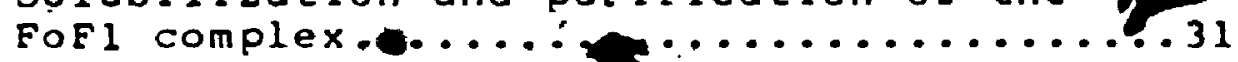

.7 Molecular Weights of M-ATpases......... 32

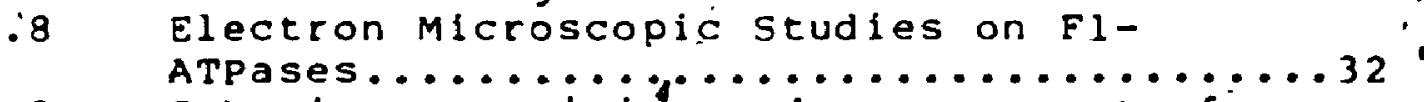

.9 Subunit composition and arrangement of

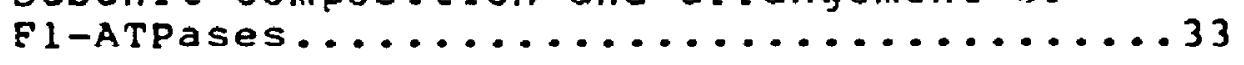




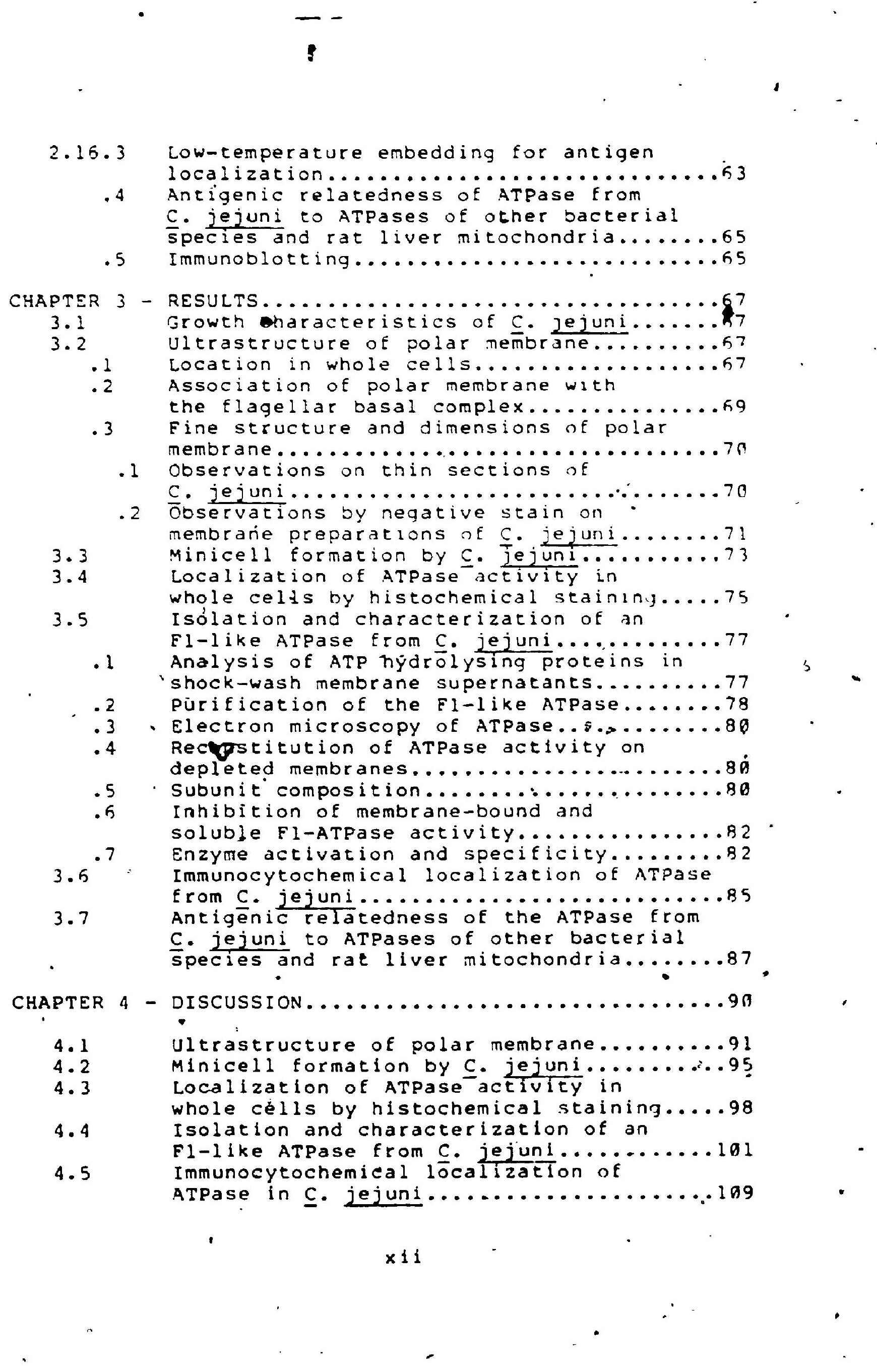




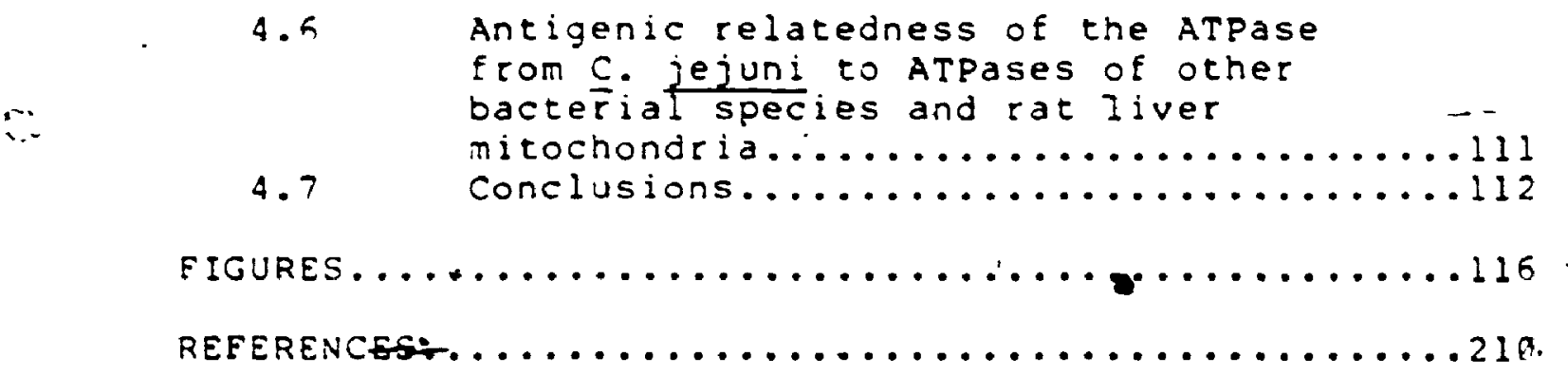

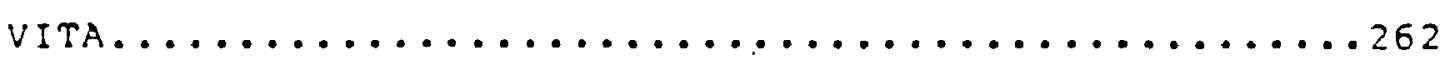

-

$x 1$ i 1 


\section{LIST OF TABLES}

Table

Page

1

Purification of soluble aTpase

Reconstitution of ATPase activity

ih depleted nembranes

Effects of inhibitors on the membrane bound and.soluble purlfied ATpase from $C$. jejuni 
Diagram of the polar membrane in

Ectothiorhodospira moblis.

Conceptual model of FOFl of

Escherichia soli.

Growth Curve for $c$. jejun:

Thin section of $C$. jejuni Eixed

with 58 acrolein and 7.258 glutaraldehyde.

Thin secition of $A$. serpens MW5

fixed.with $5 \xi$ actolein and 0.258 .

ylutaraldehyde.

cross segtion of $\mathrm{fC}$.jejuni.

cíoss section.

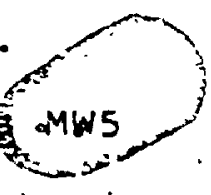

- Cross section of A. serpens MW5

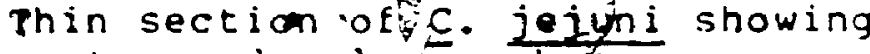

septum and polarinembtane.

Thin section of $C$. jejuni showing

septum with no associated polar

membrane.

Thin sectian of polar region of $C$.

jejuni showing association of polar membrane with the flagellar basal

complex.

Thin section of the polar region of C. $\$ 137$

- jejuni showing association of polar

membrane and the flagellar basal

complex.

12

Thin section of the polar region of $C . \widehat{I} 39$ jejuni showing assoclation of polar membrane to the flagellar basal complex.

13 Thin section of the polar region of $c$. 141 jejuni showing the association of polar membrane to the flagellar basal complex. 
Thin section of the polar region of C. 143 jejuni showing the association of polar membrane to the flagellar basal complex.

15 - Thin section of the polar region of $C$. jejuni showing the association of poIar membrane to the flagellar basal complex.

16 Longitudinal and cross seceion of $\dot{C}$. jejuni showing polar membrane and $\bar{r}$ igid cytoplasmic membrane.

French pressure cell discupted membrase 149 preparations of, C. jejuni negatively stained with ? s phosplrotungetic acio.

French pressure cell tisrupted membrthe preparation of $C$. jejuni negatively stained with 18 phosphotungstic acid.

Negatively stained memorane preparations of $C$. jejuni.

Thin section of memorane preparations from C. jejuni pie-fixed with lo $\operatorname{tanni} \bar{c}$ acid

21 Negatively stained miniceils from $E$. jejuni bearing "Elagelta.

Thin sections of minicelis from $\subseteq$. jejuni.

23 Thin sectigos of c. jejuni showing formation. $\vec{f}$ orinicelis. Negatriely"stalned whole cell of $\underline{C}$. jejubi showing minicell forming texto polar region. riembrane vesicles and flagellar debris:

Negative stain of a minicell showing hexagonal pattern in the interior. Mg 2+-ATPase activity. 
Thin sections of spheroplasts of $c$. jejuni histochemically stained for Mg2t-ATPase activity.

'Thin sections' of $C$. jejuni histochemically stained for the presence of Ca2+-ATPase activity.

Thin sections of E. coli Kl2 histochemically stained for the presence of Ca2t- and Mg2+-ATPase activity.

Thin section of B. cereus histochemically stained for the presence of Mg2+-ATPase activity.

Thin sections ó́ M. luteus histochemically stained for the presence of Mg2+- and Ca2+-ATPase activity.

Thin sections of. D. radiodurans histochemically stained for the presence of Mg2t- and Ca2+-ATpase activity.

Thin sections of A. Serpens MWS histochemically stalned for the presence of $\mathrm{Mg} 2+-$ and Ca2+-ATpase activity.

Non-dissociating gel analysis of protein profiles and ATPase activity in polyethylene glycol precipitated material from the initial shock-wash supernatant from membranes of $\underline{c}$. jejuni.

Non-dissociating-PAGE of puríted ATPasé.

Negatively stained solubilized ATPase from $C$. jejuni... cations on $\subseteq$ jejuni Arpase activity. speciflcity of the ATpase of $C$. jejuni. embedded whole cells. 
Immunocytochemical localization of $C$. jejuni ATpase on thin sections of spurr embedded whole cells.

43 Immunocytochemical localization of $c$.

jejuni ATPase on hydrogen peroxide etched sections of spurr embedded whole." cells.

14 Immunocytochemical localization of $C$. jejuni ATPase on thin sections of Lowicryl KMA embedded whole cells.. Immunocytochemical localization of $\underline{C}$. jejuni ATPase on thih sections of Lowicryl KM4 embedded whole cells.

Western blots of whole cell proteins reacted with antibody prepared against the ATPase isolated, from $C$. jejuni.

Westempblots of. whole cell proteins reacted with antibody prepared against the Fl-ATPase of E. Coli Kl2. 
The author of this thesis has granted The University of Western Ontario a non-exclusive license to reproduce and distribute copies of this thesis to users of Western Libraries. Copyright remains with the author.

Electronic theses and dissertations available in The University of Western Ontario's institutional repository (Scholarship@Western) are solely for the purpose of private study and research. They may not be copied or reproduced, except as permitted by copyright laws, without written authority of the copyright owner. Any commercial use or publication is strictly prohibited.

The original copyright license attesting to these terms and signed by the author of this thesis may be found in the original print version of the thesis, held by Western Libraries.

The thesis approval page signed by the examining committee may also be found in the original print version of the thesis held in Western Libraries.

Please contact Western Libraries for further information:

E-mail: libadmin@uwo.ca

Telephone: (519) 661-2111 Ext. 84796

Web site: http://www.lib.uwo.ca/ 


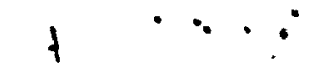

Chapter i

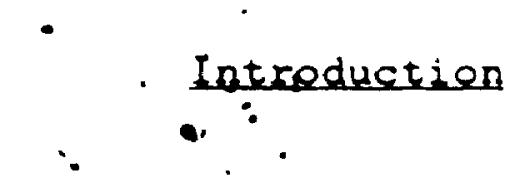

In_1963, Murray and Bifch-Andersen observed, in thin sections of Aquaspirillum serpens, "an extremely thin membramous component 200 A underneath the plasma membrane". This structure appeared to be connected to the overlying - plasma membrane by short bar-like links of regular length. and was found in association with the poles of the cell. The imembranous appearance and location of this structure led the authors to name this specialized region "polar membrane".

- In 19்6, Ritchie, et. al., described a similar structure in Vibrie fetus (now, Campylobacter fetus) and in 1968, Remsen, et. ad. further defiried the frycture in Ectothierhedespira mobtlis as being composed of "alseries of projections" arising out of the plasma membrane "shich had stalks $50 \mathrm{~A}$ long, which terminated with a knob-like structure approximately-75-80 A in diameter": In the twenty-three years which have passed since the initial reports of polar membrane the structure has been observed in a variety of polarly flagellated Gram-negative bacterial genera, includina Rhodespinillup,., Selenemonas, Chromatium, 
Vibrie and Methanecoccus (Hickman and Frenkel, 1965;

Chalcrort. èt, al...1973; Smibert, 1978; Ferris and

Beveridge, 1985; Kqual and Jarrel, 1987). However, to date. the biochemical composition and fungtion of potar membrane is unknown. Its location at the poles of the cell

surrounding the Ylagellar insertion point has led to the hypothesis that polar membrane functions in energy transductions (Murray and Birch-Andersen, 1963). As well. the component units are stricturally similar to the ATPase of the inner mitochondrial membrane and the cytoplasmic membrane of various bacterial species (Racker 1967: Harold, 1972 ) because they are all composed of stalks and knobs. A study of polar membrane in Campylobacter jejuni has been pursued to try and resolve both its structure and function.

The purpose of this introduction is to acquaint the reader with 1) the organism under investigation, 2) the structure and function of bacterial cell walls and : envelopes. with emphasis on the cell envelopes of Gram-negative bacteria and flagella basal complex, which the polar membrane is most ciosely associated with, 3) the currently known facts of polar membrane, including further elaboration on its structure; and possible function(s), 4) eucaryotic and procaryotic adenosine triphosphatases and finally. 5) an outine of the goals of this study. 
1.1 Lampylobacter jejuni : Description of the organism.

‥ Lejuni is a Gram-negative; nonsporeforming. microaerophilic, helically curved, slender bacillus (Smibert, 1978 and 1984). Various morphological forms have been observed in cultures of this organism. including s-shaped, gull-winged, comma, dimpled, and coccoid (Karmali and Skirrow, 1984; Merrell, et al., 1981; Smibert, 1978 and $1984 ; \mathrm{Ng}$, et at, 1985 ). This organism readily produces ! coccoid forms or bodies late in its growth cycle or upon exposure to atmospheric levels of oxygen (Ogg, 1962: Smibert, 1965 and 1984). This phenonmenon has led to questioning of the purity of cultures being examined.

i. jejuni is motile by means of a singte, unsheathed. polar flagellum at one or both ends of the cell. The flagellum may be two to three times the length of the cell, and propels the organism in a characteristic corkscrew-like motion (Smibert, 1984 ).

d. jejuni causes abortion in sheep and enteritis with fever in man. It has been found, over the last few years. . to cause as much enteritic disease in man as Salmonella and shigellas and is therefore considered an important humán intestinal pathogen (Smibert, 1984 ). This organism can be found in the intestinal tract of poultry, dogs, cats, sheop. rabbits, monkeys, sea gulls, cattle, and pigs (Smibert, 
196b, 1969, 1978, and 19841.

1.2. Ultrastructure of the Bacterial Cell Envelope

The taxonomic classification of bacteria primarily begins with the use of the Gram reaction (Gram, 1884). This staining procedure has resulted in the division uf bacteria into two major groups, Gram-positive and Gram-negative. This staining procedure showed initial structural and molecular dififerences between the outer layers of bacteria that retain the purple iodine-gentian violet complex after extraction with polar solvents such as alcohol or acetone (Gram-positive), as compared to those that do not do sn (Gram-negative). The lack of retention of this dye complex in Gram-negative bacteria is now thought to be $a$ result of the dissolution of the outer membrane by the polar solvent allowing the cell to become leaky (Beveridge and Davies. 1983). A few anomalies to this system of classification dos exist. The archaebacteria possess cell walls of a simple organization. The cell envelopes of the archaebacteria Sulolobus acidocaldarius and Halebacterium cutirubrum consist of a cytoplasmic membrane and external to this a regularly-structured array of glycoprotein subunits (Kandlor. 1982; Stoeckenius and Rowen, 1967: Weiss. 19741. Butyrivibrio fibrisolvens possesses a Gram-positive wall 
type but stains Gram-negative (Eheng and Costerton, 1977) and Deinoceccus radiodurans has a Gram-negative wall type but stains Gram-positive (Thompson and Murray, 1982)

Gram-positive eubactéria possess a relatively simple cell wall profile. Iñtial studies on the cell wall of Baclilus sereus revealed the presence of a thick, densely staining, mucopeptide layer. At first, a distinct plasma memb̄rane was not seen (Chapman and Hilijer, 1953), but the development of better fixation and embedding techniques for the electron microscope resulted in the visualizatzon of a 7.5-8.0 nm double-track cytoplasmic membrane in a variety of Gram-positive eubacteria (Murray, 1957; Kellenberger. and Ryter, 1958; Van Iterson, 1961)

The cell walls of Gram-negative bacteria are pore complex than those of Gram-positive arganisms. In the early studies of the surfaces of Gram-negative bacteria there were difficulties in observing more than a single dense surface. layer. The ilsst clear demonstration of the plasma membrane and the cell wall as two separate structures was accomplished by Kellenberger and Ryter (1958). By the use of special fixation and embedding techniques they showed that, in Escherichia celi, the plasma membrane was a sirigle dense layer, 6.0-8.0 $\mathrm{nm}$ thick, and the cell wall was a triple-layered structure; consisting of two outer dense layers separated by a less dense layer. with a total diameter of 6.0-9.0 nm. One of the components of this 
triple-layered wall was a second double-track membrane which was termed the outer membrane (Birch-Andersen et al. 1953). As techniques improved further it was found that an additional layer was present. A dense layer was seen between the plasma membrane and the cell wall, first in Vitreoscilla (Costerton, et al. , 1961), Spirldium serpens (Murray, 1963). and Meraxelta (Ryteŕr and Piechaurd, 1963), and later in a wide range of Gram-negative bacteria (Glauert and Thornley, 1969). This was a $2.0-3.0 \mathrm{n}$ thick layer. of muren, or $\therefore$ peptidoglycan, aligned between the two membranes (De Petris. - 1965, 1967: Murray et as . 1965).

Today it is known that many bacteria possess cell envelopes of even greater complexity. Additional layers. have been found external to the peptidoglycan layer of Gram-positive and the outer membrane of Gram-negative . eubacteria. These layers include capsules, slime layers: and régularly-structured arrays of protein (Beveridge, $1981)$

1.3. Cemponents of the Bactertal Cell'Envelope

\subsubsection{Quter Membrane}

The outer membrane of Gram-negative bacteria appears in thin section as a wavy, double tracked membrane varying. from 6 to $10 \mathrm{~nm}$ in diameter according to the species. 


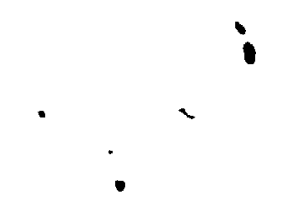

Projections and blebs from this membrane are frequently seen (De Petris, 1967). The outer membrane can

- be separated from the cytoplasmic nembrane because of its greater density due to the presence of lipopolysaccharide (LPS) (Osborn et al., 1972). The isolated outer membrane has beep found to be composed of approximately 20-25\% phospholıpid. 30x 11popolysaccharıde, and 45-50\% protein ( $\mathrm{Di}$ Rienzo et al. 1978$)$.

The phospholipld is found mainly in the inner leatlet of the membrane bilayer, and the Iipopolysaccharide is associated with the outer leaflet (Funahara and Nikaido. 1980) The phospholipids of the outer membrane are quantitatively similar, to, but qualitatively different from those of the cytoplasmic membrane in E. cell (White, et al.. 1972; Osborn, et as.. 1972). Outer memberee is enriched in phosphatidylethanolamine as compared to the cytoplasmic membrane (Rottem el al. 1975)

Lipopolgsaccharides are common componerits of the cell envelops of all Gram-negative eubacteria and are apparently unique to these organisms (Osborn, 1969). LPS is an amphipathic molecule corisisting of complex phosphorylated heteropolysaccharides covalently linked to a specific glucosamine-containing lipid, Lipid A (Luderitz et al. 1fm: Usborn:" 1969$) \ldots \cdot$ Lipid $A$ is embedded in the outer leaflet of the outer membrane and the heteropolysaccharides 
extend outwards tran the cey surtace 1 Beveridge. 1981. iosterton et a1 . 1974,

The protein composition of the outer memorane ditters irom that of the cytoplasmac membrane in that it contains. small variety of proteins in large quantities I Inouye.

1979 ) It has, therefore, been relatively easy to purity and characterize these major proteins. The outer membrane of wild-type E. soli K-12 contains at least three classes ci major proteins: (i) matrix proteins (Rosenbusch. 1yi4: Ui Kienzo et at. 1978; Osborn and wu. 1980) which when viewed by negative stain on the electron microscope appear as a tightly packed lattice with a $7.7 \mathrm{~nm}$ repeat (Rosenbusch. 1974: Steven et al., 1977). These proteins are thought to form pores allowing passive diffuston tNakae, 1970 . 1 libbl (ii) The omp A protein (also known as the tolg protein) is found in large quantities in the surface of the outer leaflet of' the outer membrane (Inouye and Yee. 1972). (ump A. -is thought to function in F pilus-mediated conjugation (Manning et al. 1976; Manning and Reeves. 1976), and as bacteriophage receptors (Datta et al., 197?). (iii) lipoprotein (also known as the Braun protein) which my - function in maintaining the integrity of the outer membrane structure (Braun and Rehn, 1969: Braun and Sieglin, 1970: Braun and Wolff, 1970; Di Rienzo et ab.. 19781. Tun to 
twenty minor protein species are also present in the outer membranes of Gran-negat lve eubacteria (Inouye, 1979). These proteins function in the transport of nutrients: vitamins and metals, and may also act as bacterlophage and bacteriocin receptors (Di Rjenzo et al. 1978).

- The outer membrane 1 remarkably devold of enzymatic activity. A protease and $\not \dot{z}$ phospholipase have been 1 solated from the outer membrane of E. colt (MacGregor et al. , 1979; Bell aㅗ. (1971).

\subsection{Peptzdeglycan}

Peptidoglycan is a fundamental polymer that is a common component of the cell walls of Gram-positive and Gram-negative eubactaria, Rickettsiae and blue-green bacteria. This structure is composed of $N$-substifuted glucosamine and muramic acid (3-0 lactylglucosamine) linked together by 1-4 beta bonds (Rogers. 1983). It is the peptidoglycan that is responsible for the ridigity and integrity of the shape of the celi. When peptidoglycan is degraded. for example by lysozyme, the bacterium tends to lose its characteristic shape and to form a spherical body known as a protoplast in Gram-positive organisms and a spheroplast in Gram-negatives (Rogers et al., 1980). The 
chemical compostion of peptidoglycan has been worked out over a period of thirty-five years following the classical studies of Weidel (1950) and of Salton (1953).

The polysaccharide or glycan chains of peptidoglycan are crosslinked by short peptides, in any one peptzdoglycan. of a $11 m i$ ted number of amino acids

Four basic types of peptidoglycan have so fiar been determined (Ghuysen, 1968) and are differentiated by the way in which the peptides are linked together. However. the range of amino acids iound in peptidoglycans trom different species of bacteria is large. A complicated classification. of the different types of peptidoglycan taking into account this wide variation has been devised by Schleifer and Kandler (1972).

The peptidoglycan of Campylobacter species has boen found to contain alanine, lysine, glycine, glutamic acid. aspartic acid, and either cysteine or diaminopimelic acid (Keeler et al., 1966). The peptidoglycan of intestinal and venereal strains of $\mathcal{G}$. fetus is composed of muramic acid. glucosamine, alanine, glutamic acid, and diaminopimelic acid ' $(1: 1: 2: 1: 1)$ and the repeating unit in the polymer was presented as Gle NAC-MurNAt-L-ALa-D-Glu-meso-Dpm-D-Ala (Smibert, 1978 ). 


\subsection{Feriplasmic space}

The periplasmic space is the region between the plasma and outer membranes of Gram-negative eubacteria. This space constitutes some 20-40. per cent of the total cell volume and is distinguished by a distinct ionic composition and the presence of a unique series of proteins (Beveridge, 1981 ).

This space may be compartmentalized by the presence of adhesion zones or sites connecting the plasma and outer membrane (Bayer, 1968). The proteins found within this area pertorm a variety of functions. Some have a catalytic function, converting various substrates into forms for translocation by specific carriers present in the cytoplasmic membrane (Kellermann and Szmelcman, 1980; Lo, 1979); others can be classed as hydrolytic enzymes, some of which are responsible for the destruction of antibacterial agents penetrating the outer membrane (Wetzel et al., 1910: Curtis et a‥1. 19721.

\subsection{Eytoplasmic Membrane}

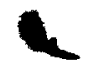

The cytoplasmic membrane appears, on thin section, as a $7.0-8.0 \mathrm{~nm}$ thick double track layer surrounding the cytoplasm "(De Petris, 1965, 1967). There is little ditierence between the plasma membranes of Gram-pusitive 
and Gram-negative bacterla except for the presence of lipoteichoic acid in the membranes of the Gram-positive organisms (Ward, 1981). Bacterial cytoplasmic mombranes are composed of approximately 50-70x protein and 20-30x lipid (as reviewed by Rogers et al, 1980).

Most of-the lipid portion of the membrane consists of phospholiplds such as phospatidylglycerol. diphosphatidylglycerol'(cardiolipin) and phosphatidylethanolamine (Lechevalier,.1977). The phospholipld composition of the cytoplasmac membrane ut campylobacter species includes, in addition to those mentioned above, phosphatidyl inositol, phosphatidyl serine and the glycolipid digalactosyldiglyceride (Smibert, 1978): The fatty acids of bacterial lipids are generally of the saturated, monounsaturated, or cyclopropane variety (Kaneda, 1977). "The major fatty acids found in the plasma membrane of $\mathrm{c}$. jejuni were $\mathrm{C}-10:, \mathrm{C}-12: 0, \mathrm{C}-14: 0$ present in small amounts and in larger amounts $C-16: 0, c-16: 1$, and C-18:1 (Simibert, 1978):

When cytoplasmic membrane is ${ }^{-}$disageregated by heating at $100 \circ \mathrm{C}$ fog one minute in $1 x$ SDS and electrophorsis is applied in a polyacrylamide gel, approximately 30-40 protein bands can be separated (as reviewed by Rogers et al., 1980). Rottem and Razin (1967) have suggested that gel patterns from unidirectional electrophoresis of membrane propteins are 
suiticiently characteristic to be used as "inger prints" in the classitication of Mycoplasmas. Using the O'Farrell

11975, two dimensional electrophorsis method, a very much

larger number of spots can be seen in plasma membrane prepartions. Approximately 140 spots were visualized in membrane preparations from Acholéplasma laidlawij (Archer ét al. (1978). The number and variety of proteins present in this membrane suggést it to be multifunctional in nature (Salton. 1974). To date, plasma membrané has been shown to possess the enzymes responsible for oxidative phosphorylation, electron transport, wall biosynthesis and active transport of elements. nutrients and metabolites (Saltion. 1971. 1974). Most of these enzymes have been

- identified by using crossed immunoelectrophoresis and include dehydrogenases utilizing succinate.

1,6-phosphogluconate, dihydro-orotate, two utilizing NADH, malate. glycerol-3-phosphate, lactate and gluamate as substrates: an adenosine triphosphatase and a proteasu Johansson and Hjerten. 1974; Johannson and Wroblewski. 1978; Owen and Salton, 1975, 1977; Owen and Smyth, 1977; Salton, 1978: Salton and Owen, 1976: Smgth et al.. 1976 . $1978)$

Abram ( 1965 ) showed that, when negatively stained with phosphotungstate ( $\mathrm{pH} 7.0-7.2)$, the plasma membranes of Bacildus stearothermophilus were studded with particles. 
approximately 6.5-8.5 nm in diameter that were deduced to be on the inner surface of the membrane. These particles were attached to the membrane by fine stalks of the order of $5 \mathrm{~nm}$ long: Similar particles, found on the plasma nembranes of Streptococcus faecalis and Micrococcus lysodeikticus, have. - been stripped.from the membranes (by washing in a low ionic strength buffer plus EDTA, ethylenediamine tetraacetate), purified and shown to possess ATPase activity (Oppenheim and Salton. 1973; Schnebli et al. :1970; Munoz et al., 1968)

The location of the ATPase activity on the cytoplasmic side of the plasma membrane habeen demonstrated in $A$. lysodeikticus by two methods; (1) antiserum prepared against the purified ATPase was reacted with protoplasts and. isolated membrane preparations intibiting the ATPase. activity in the membrane prepartis.ss but not in the intact protoplasts (Oppenheim and Salton, 1973: Salton, 1978), and (2) ferritin labelled antibodies to the purified ATPase were found to bind to membranes in a patternusimilar to that of _the particles seen by negative staining on unreacted membranes (Oppenheim and Salton, 1973).

The inner leaflet. of the cytoplasmic membrane of - Campylebacter species is thickened at the polar region (Ritchie et al., 1966). It possesses on its inney surface a structure termed polar membrane. This structure, as 
mentioned earlier, is also found in a variety of polaraliy flagellated bacteria and will be discussed at length later in this review.

1.3.5. Elagella

C. jejuni is actively motile by means of a single polar flagelium at one or both ends of the cell (Smibert. 1978). The flagella are composed of three parts: (1) the basal body. (2) the hook, and (3) the iflament

The Ilagellar baṣal complex in Gram-negative bacteria

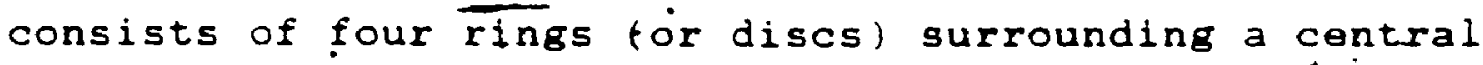
axial rod (Doetsch and Sjobald, 1980). These.rings were originally designated by DePamphilis and Adler (1971) according to their-position and association with various structureg in the cell envelope of $E$. colit; the L ring for its association with, the outer (Iipopolysaccharide)

membrane, the $P$ ring with the peptidoglycan, the S ring (for supramembrane) just above the cytoplasmic mefbrane. and $M$ ring associated with the plasma membrane. Some basal bodies are more complex. This structure in Caulobacter crescentus has five rings (Johnson et al: 1979) and in A. serpens, $\underline{V}$ chelerae, and $C$. Letus a muber of concentric rings (CMR's) are found surrounding the central axial rod and appear to be located between the $L$ and $P$ rings (Coulton and Murray, 1977 , 
1.978: Ferris and Beveridge, 1984). In $\underline{\mathcal{C}}$. Letus the $\mathcal{i}$ and $M$ rings were found to be associated ith the plasma membrane (possibly with the outer and innef Hydrophilic surtaces. respectively), the $\mathrm{L}$ ring was embedded in the outer membrane and the $P$ ring was associated with the peptidoglycan /Ferris and Beveridge, 1984). In both $\underline{A}$. serpens ang $\subseteq$ fetus fibrous material was fiound associated with the proximal end of the basal complex emanating from the M ring (coulton and Murray, 1977, 1978; Ferris and Beveridge, 19841. "The basal body is thought to function in. two ways: (1) as an anchor of the flagella to the cell, and (2) as "motor". with the $M$ ring generating torque for rotation by interacting with a "stator" (possibly the S ring or the outer surface of the axial rod,. The $L$ and $P$ rings are thought to function as bushings allowing free rotation of the axial rod in the cell wall (Berg, 1974, 1975; Lauger; 1977; Macnab, 1979).

The hook is located at the base of the filament. It. is approximately $900 \mathrm{~nm}$ long and consists of a single protein of 42.000 daltons in E. soli and 33.0uU daltons in Bacillus subtilis (Kagawa et al., 1976; Silverman and simon. 1972 ; Dimmitt and Simon. 1971). This structure is thought to act a "universal joint" between the basal brdy and the filament (Silverman and Simon, 1977 ). 
The filament is a tubule varying in size from 12 to 15 nï in diameter. composed of identical protein subunits (flagellin) in one of two configurations (Silvermon and Simon, 1977 ). The arrangement of the flagelin subunits in intact flagella gives rise to two different types of filament configuration: an A form, which is characterized by helically connected globules, and a thick-lined $B$ form in which helical organization is not observed (Lowy and Hanson, 1965). The flagella of $\mathrm{C}$. fetus are approximately $21 \mathrm{~nm}$ in diameter during the mid to late stationary phase of growth and about $18 \mathrm{~nm}$ in diameter after 24 hours of growth (McCoy et al. , 1976).

\subsection{Pelar Membrane}

A structure comprised of an ordered array of densely staining short bar-like particles arising out of the eytoplasmic membrane was first described in A. serpens by Murray and Birch-Andersen (1963). They termed this structure "polar membrane". Cohen-Bazire and Kunisawa (1963) observed a similar structure in Bhedespiritulum rubrum and termed it a "polar cap". Ritchie et al. (1966) noted the presence of this structure in $Y$. fetus (now $\mathcal{C}$. fetus) and chose to describe it as a complex cytoplasmic membrane. To date the term "polar membràn" seems to have been adopted, al though 
It is slightly misleading in that the 'structure is not always found at the poles of the cell and when well resubw. in thin sections it does not appear to have the structure of membrane This structure has also been found in a variety of other bacterial species including Ectothiorhodospira mobilis (Remsen et al., 1968), Selenomonas ruminantium (Whalcroft et al. . 1973). Vibeo cholera (Ferris and Beveridge, 1984), and Methanococcus voltae (Koval and Jarrel, 1987).

The best description to date of polar membrasa comes from the work of Remsen et al. (1968) on Ectothiorbodospira mobilis. This structure was about $30 \mathrm{~nm}$ thick and ronsisted of plasma membrane $(7.5 \mathrm{~nm})$, a dense area about lu $\mathrm{nm}$ thick. and series of projections which terminated with knob-like structures approximatley 7.5 to $8.0 \mathrm{~nm}$ in diameter. Figure 1 illustrates the pertinent morphology of polar membrarieand proximity to the flageilar basal complex (Figure 4 ) . In $\mathrm{L}_{-}$ tetus the polar membrane is usually found at. the flagellated pole, however, its presence has also been observud inar the point of septum formation and presummably the site si insertion of a future flagellum (Ritchie et al!. Ijbb) Polar membrane covers the inner surtace of the cytrplasmic: membrane and is near to the flagellar basal complex, but has never been seen to cover the membrane!at the base of this structure or to join up' with any component of it ( Murray and 
Birch-Andersen. Y963: Ritchie et al:, 1960: Coulton and Murray 1978 , It has also been observed that the cytoplasm in the polar regions associated with polar membrane is remarkably devoid of ribosomes (Murray and Birch-Andersen. 1963; Ritchie et al. . 1966).

The location of this structure has led to the hypothesis that polar memorane, may be involved in energy transformations, such as the liberation of energy for flagellar rotation or the synthesis of new cell wall (Murray and Birch-Andersen, 1963). Ritchie et al (1966) propused that the complex cytoplasmic membrane (polar membrane) may contribute a torsionarforce at some stage of development and influence the conformation of the organism, as at the : time this structure had been identified in only spirally curved bacterial species. This hypothesis was deemed. unlikely with the discovery of polar membrane in the. straight rod Chromatium (Smibert, 1978).

1.5. Eucaryotic and Procaryotic Adenosine Triphosphatases (ATEases)

All forms of living cells conserve energy in chemical compounds, especially in ATP. Enzymes are required for the synthesis of and hotrolysis, of these energy rich compounds. 


\section{All ATP-hydrolysing enzymes are not usefully regarded}

as ATPases. There' is a large group of non-specifia phosphatases for wtrich ATP is only one of a wide range of possible substrates (e.g. Alkaline phosphatases (Leonard and Provenza, 1972)). Therefore for the purposes of this review, an enzume will only be regarded as an ATPase if its activity is largely confined to nucleoside triphosphates and ATP is one of its optimal substrates.

- To date three broad groups of ATPases have been distinguished: (1) ion-transporting ATPases. (2) ATPases associated with contractile systems, and (3) proton-translocating ATPases.

\subsubsection{Len-tranṣperting ATPasés}

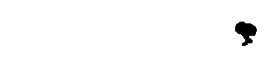

A large group of enzymes of this class have been. $\widehat{\wedge}$ identified in the plasma membranes and other membrane sites Ot eucaryotic cells. These enzymes normally are involved in ATP hydrolysis, using the energy so derived for active ion transport. However, when ion gradients become steep enough, these enzymes may function in a synthetic mode (e.g. the $\mathrm{Ca}^{2}+-t r a n s p o r t i n g$ ATPase of the saŕcoplasmic reticulum (Hasselbach and Suko, 1974)).

This class of enzymes includes (i) monovalent and divalent cation transporting ATPases, and (ii) anton transporting ATPases. 

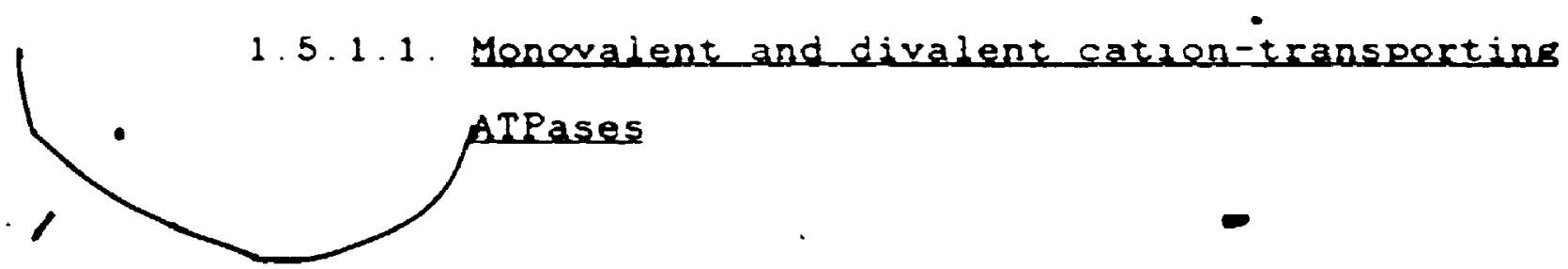

This group of enzymes includes the $\mathrm{Na}^{+}, \mathrm{K}^{+}$-dependent ATPase of mamalian plasma membranes, the $K^{+}$. $H^{+}-A T P a s e$ of fungal. plant and gastric parietal cell plasma membranes. $\mathrm{Ca}^{2}+$-ATPase of the sarcoplasmic reticulum, vacuolar proton ATPases and a $k^{+-A T P a s e}$ found in $E$. coli.

The exsistence of a $\mathrm{Na}^{+}, \mathrm{K}^{+}$-dependent ATPase in the plasma membranes of mammailian ceils was ifrst recognized when it was found thet the sodium pump of nerve axons was coupled to ATP hydrolysis (Hodgkjp and Keynes, 1955). A similar enayme system in erytheste plasma membranes was found to be dependent on $\mathrm{Mg}^{2+}, \mathrm{Na}^{+}$, and $\mathrm{K}^{+}$(Glynn, 1957). These enzymes function in the maintenance of $\mathrm{Na}^{+}$and $\mathrm{K}^{+}$ - gradients across plasma membranes, bulk transport of monovalent cations (Epstein, 1969), and less directly, in the transport of other substances coupled to electrochemical gradients set up by the $\mathrm{Na}^{+}, \mathrm{K}^{+}$-ATPases (Bronk and Lesse, 1974 )

These $\mathrm{Na}^{+}, \mathrm{K}^{+}$-dependent ATPases, when purified, are found to be composed of a 106,000 dalton alpha-subunit (Hastines and Reynolds, 1979; Esmann et al., 1980) and a. 37.000 to 40.000 dalton beta subunit (Hastings and Reynolds. 1979: Esmann et al., 1980: Sabatine et al. 1981). 
-

As well, a 10,000 to 12,000 dalton proteolipid has been indentified in purified preparations of these enzymes and has been termed the gamma subunit (dokin et al.. 1973: Forjush et al. (1978).

$\mathrm{Na}^{+}, \mathrm{K}^{*}$-dependent ATPases have been crystallized in the membrane, forming two dimensiorrl crystals, by using -vanadate (Skriver et asl., 1981: Maunsbach et al.. 1983) and itrorganis phosphate ( $\mathrm{Pi}$ ) (Herbert et al. 1982) is stabilizing ligands. Negative staining of these membrane crystals showed distinct surface particies of $3 \mathrm{U}$ to $\mathrm{b} \mathrm{nm}$ in diameter (Deguch et al., 1977: Skrıver et al., 1981).

$\mathrm{Na}^{+}, \mathrm{K}^{+}$-dependent ATPases are inhibited by ouabain. vanadate and diethylstilbesterol (De Meis and Vianna. 1979: Sarkad1, 1980).

The plasma membranes of fungl, plants, and gastric parietal cells possess $\mathrm{K}^{+}, \mathrm{H}^{+}$-ATPases. These enzymes are composed of a major subunit of approximately 100,000 daltons (Malpartida and Serrano, 1980,1981: Dufour and Gorteau. 1978; 'Addison and Scarborough, 1981; Bowman et al., 1981; Bara and Serrano, 1982; Uchida et al., 1985), and are inhibited specifically by vanadate, diethystilbesterol, and dicycolhexylcarbodiimide (DCCD), but not by ouabain, azide, oligomycin or molybdate (Goffeau and Slagman, 1981: Delhez et al., 1977; Serrano, 1978; Gallagher and Leonard, 1982: Hodges, 1976; Bowman et al, 1978; Bowman. 19831. 
The iaz+-transporting ATPase of sacroplasmic reticulum is responsible tor the cessation of muscle contraction aycles by removing cas + from the sarcoplasm into the sarcoplasmic reticulum cavities (as reviewed by Moller et al. 1982). These enzymes range in molecular weight from $90,00 u$ to 150,000 daltons and appear to be composed of a single subinit type (Machennan et ąt., 1971, MacFarland and Inesi. 1971: Meissner et al., 1973). They are located on the outer surface of the sarcoplaspic reticulum and have. been crystallized in the membrane, forming two dimensional crystals. by using vanadate as a ligand (Dux and Martonosi. 19831. When negatively stained, these enzymes appear as particles of approximately $4.0 \mathrm{~nm}$ in diameter connected to the Jymbrane via a stalk 2.0 nm long (Jilka et as!. 1975: Lux and Martonosi. 1983). These Ca2+-ATPases-have the same inhibition pattern as the mammalian $\mathrm{Na}^{+}, \mathrm{K}^{+}-\mathrm{ATPases}$ (Josephson and Cantley, 1977: O'Neal et al. . 1979).

The vacuolar proton ATPases are found in eucaryot membranes such as endoplasmic reticulum, the Golgi complex and secretory vacoules. These enzynes are distinguished Irom the aforementioned ones by virtue of their inhibitor specificites. They are not inhibited by oligomycin. efrapeptin, azide, aurovertin (mitochondrial Fi-ATFase inhibitors), vanadate or ouabain ( $\mathrm{Na}^{+}, \mathrm{K}+-\mathrm{ATPase}$ 
inhibitors). but are specifically. inhibited by alkylating reagents such as $N$-ethylmaleimide (NEM) and 4-Ehloro-7-nitrobenzo-2-axa-1.3-diazol (NBD-C), istone at al. 1983; Forgae et al . 1983; Galloway et aㅣ. 1983: Glickman etal. 1983: Ohkuma et al., 1982; Bowman, 1983). A.K* transporting ATPase. has also been isolated irom the plasma membranes of the bacterium E. coli and found $t$ be associated with the Kdp trangport systemiepsteln et al. 1978. . This enzyme is stimulated by $K^{+}$and is not inhibited on the meiprane by DCCD which inhiblts the Ca2+. Mge+-ATHasez . $\because F_{1}$-ATPase) of this organism (Epstein et al . 19781

1.5.1.2. "Anion-Transeorting ATPases

These enzymes are stimulated by HCO 3 - and difier from $\mathrm{Na}^{+}, \mathrm{K}^{+}$-dependent ATPases in that they are not inhibited by ouabain (Spenney etal., 1973; Kinne-Saffran and Kine, 1974: Simon et al. . 1971)

1.5.2. ATPases associated with contractite systems This group of Atpase activities are associated with il famentous and other non-membrarious structures in the . cytoplasmic matrix of eucaryotic cells. The activity of . these enzymes is assumed to be related to motility and 
contraction events, such as the myosin ATPase of muscle cells (Tonomura and Inoue, 1974). These enzymes are not inhibited by ouabain or oligomycin (Tonomura and Inoue. $1974)$

\subsubsection{Proton-Translocating ATPases}

\section{Enzymes of this group form part of the inner}

mitochondrial membrane. the grana membranes of chloroplasts and the plasma membranes of bacteria. In mitochondria and chloroplasts of eucaryotes the ATPase is required for the formation of ATP from ADP. In procaryotes the ATPase is located in the plasma membranes of both aerobic and anaerobic species (Downie et al., 1979).

These proton-translocating ATPases àre a part of a complex of two enzyme systems found in energy-transducing membranes: they consist of the electron transport proteins and the proton ATPase complex (H+-ATPase) (Ameel and Pedersen. 1983), and they appear to be chupled by an electrochemical gradient of protons generated by the redox components (Mitchell, 1966, 1981). The H+-ATPases function by (1) allowing a flow of protons across the membrane ( $i$. $\theta$. the translocation stepl, (2) catalysing the formation of ATP from ADP and inorganic phosphate $\left(P_{1}\right)$, and (3) directing protons in such a way as to use the energy stored in the 
electrochemscal gradient to produce high ATP cóncentrations i.e. the coupling step) (Anzel and Pedersen. 1983).

Oxidative phosphorylation is, as with many enzymatic reactions, reversible and ATP-hydrolysis can be used to induce the formation of an electrochemical gradient of protons (Amzel and Pedersen, 1983). In the anaerobic bacterium strep. faecalis the 20 wivo direction of the - H+-ATPase is toward hydrolysis of ATP (Abrams, at al. 1976). In the mitochondria of animal cells and in most aerobic bacteria the physiological direction of these enzymes $1: j$ primarliy toward ATP synthesis (Amzol and Pedersen, 1y83) For this reason. these enzymes have been,termed ATP synthase dor synthetase, and those that function primarily in ATP hydrolysis have been called $\mathrm{Mg}^{2+}$. Ca2+-ATPases I Eutal and Kanazawa, 1983). This latter term is somewhat confusing,." because it tends to suggest the transport of divalent cations rather than the translocation of protons. These proton-translocating ATPases are commonly reterred to as H+-ATPases (Eutal and Kanazawa, 1983)

The $\mathrm{H}^{+}-$ATPase complex consists of two main portions. the $F_{1}$ or peripheral membrane portion and the Fo or integral membrane portion (Figure 2 ). Fl, an extrinsic membrane protein, is the catalytic portion and consists of typically ifve subunits, alpha, beta, gamma, delta, and epsilon (Futai 
and Kanazawa, 1983,. The Fo portion is a transmembrane complex. which mediates proton translocation between the external and internal compartments of the organelle lor organism) (Futal and Kanazawa, 1983). The Fo portion has not been as extensively studied as the $F_{1}$, portion, but the subunits $(a, b$, and $c$ ) from $E$. coli have been identified' in brochemical and genetic studies (Foster and Fillingame, 1979; tiay and Walker, 1981: Hansen et al. 1981; Kanazawa et al., 1981,. A third portion, called I", has been indentified and functions as a regulator protein preventing the hydrolysis of newly syntheszzed ATP (Pederson et al., 1981; Ernster et all., 1979,

Studies of the $\mathrm{H}^{+}$-ATPase complex began in organeiles such as mitochondria and chloroplasts and followed in bacteria. The results from these studies suggested a universal nature for these enzyme complexes, with their structure and basic functions having remained virtually unchanged throughout evolution (Abrams, 1965: Schnebli and. Abrams, 1970; Harold et al., 1969; Steck and Fox, 1972; Kagawa and Racker, 1966: Catterall and Pedersen, 1971). The remainder of this review will concentrate on the $\mathrm{H}^{+}$-ATPases of bacteria with any differences to the eucaryotic enzymes being mentioned throughout.

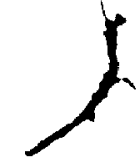


1.5.4. Bacterial $\mathrm{H}^{+}$-ATPases

The $\mathrm{H}^{+}$-ATPases isolated from procaryotic microorganisms are generally very similar, although there are specific differences. Therefore, in order to examine the development of the current ideas about the structure and function of bacterial ATPaser, this section will generally provide an overall picture rather than separate reports on individual bacteria.

Pinchot and Facker (1951) provided the irst tentative report of oxidative phosphorylation in a fractionated. bacterial system using cell free extracts of E. coli. It was later shown, in Alcaligenes, that this activity could be Tractionated into membranes and a soluble fraction (Pinchot. 1953 , which could be reconstituted to form a coupled phosphorylating system (Pinchot, 1957): .

The presence of an H+-ATPase localized in the plasma membranes of bacteria was demonstrated in a study of Strep. faecalis (Abrams et al., 1960). Voelz (1964) demonstrated the presence of ATPase activity on membranes in thin sections of $E$. coll and $B$, cereus by using a.cytochemical 'stain specific for ATPase activity. Negative staining of membrane preparations of several bacteria has shown the presence of "knobs" protruding trom the membrane (Oppenheim and Salton, 1973; Abram, 1965; Asano et al., 1973; Jones and 
Redfearn, 1967). These knobs were found to be ATPase, confirming the observation previously made with mitochondria, and they were localized on the inner face of. the plasma membrane (Oppenherm and Salton, 1973).

1.5.5. Selubilization and Purification of the El portion

I. It was first shown, in 1962, that the membrane-bound ATṔsepactivity of M lysodeikticus could be released by a shock wash using cold water and that this solubilized fraction could be reconstituted in the shock washed membranes producing oxidative phosphorylation (Ishikawa and Lehninger, 1962). Since then, similar procedures using fow ionic strength butfers in the presence of EDTA have been employed to solubilize' the membrane-bound ATPases of many bacterial species including strep faecalis (Abrams. 1965), B. megatérium (Mirsky and Barlow 1971; Ishida and Mizushima. 1969), B'. stearothermophidus (Hachimori et el., 1970), Azotobacter vinelandij (Pandit-Hovenkamp 1967; Ackrell and Jones. 1971), M. Lysodeikticius (Munoz and Salton, 1969), E.

- celi (Kobayashy and Anraku, 1972; Davies and Bragg, 1972; Vogel and Steinhart, 1976), Rhedepseudemenas sphaeroides (Molandri et al., 1872), Alaalirenes faecalis (Adolfsen and Moudrianakis, 1971), Lactobacillus casei (Biketor et al. 1982), Clestridium thermeaceticum (Mack Ivey and Ljungdhl, 
1986), Mycobacterium phlei (Kalra, et al., 1975)" In some microorianisms, such Rhedespirillum rubrum / Bengis-liarber. and Gromet-Elhanan, 1979) and Mreeplasma Landlawil (Coxpt a]., 1978), it appears that, as with chloroplasts or.

mitochondria, the ATPase cannot be solubilized by shock wash procedures:

Alternative methods for solubizing the $F_{1}$ ATPase from membranes include (i) extracting the membranes with

N-butanol or chlorotiorm (Salton and Schor, i972, 1974 ; Ishikawa,. 1970), (ii) treatment of the membranes with Triton X-100 (Hanson and Kennedy, 1973; Reed and Raveed, 1972). (iii) passing washed membranes through a French pressure cell , Lucke and Klemme, 1976), and (iv) sonication (Baccarini-Melandri et al. 1970).

Purification methods include precipitátioñ. with ammonium sulfate (Futai et al., 1974; Nẹlson et âl., 1974) or polyethylene glycol (Vogel and Steinhart, 1976: Vogel et al., 1978). followed by ion exchange chromatography in DEAE cellulose (Brass and Hou, 1972, 1975; Futai et al., 1974; Senior et al., 1979) or DEAE Sephadex (Hanson and Kennedy. 1973), and gel filtration using Sepharose 6B (Bragg and Hou.' 1972; Vogel and Stein hart, 1976; Vogel et al.. 1978) or Biogel A (Futai et al., 1974; Nelson et al., 1974). Most 
of these methods yield $F_{1}$ preparations that can bind to Fi-depleted membranes and reconstitute energy-linked reactions and it is this result which determines the feasibility of a purification method. Presumably, a purified enzyme that cannot bind to depleted membranes or reconstitute ATPase activity on the membrane has been altered in some form during preparation.

The $F_{1}$ from $M$ phiei was purified in a single step by chromatography on a Sepharose-ADP affinity column I Kalra e $\bar{t}^{-}$ at., 1975).

1.3.6. Solubilization and Purlitication of the $F_{1} F_{0}$ complex

The Fi Fo-ATPase complex has been solubilized from E. coli membranes using cholate or deoxycholate (Niewenhuis et al., .1974) and from the membranes, of $C$ pasteurianum and $M$. - phlei-using. Tritan X-100 (Clarke and Morris, 1976: Lee et -a . 1976). This complex has also been isolated trom the thermophilic bacterium PS3 (Sone et al., 1975)

Puriffcation of this complex has beer accomplished by sucrose density-gradient centrifugation (Hare, 1975), DEAE-cellulose chromatography (Foster and Fillingame, 1978,), Sepharose-4B column chromatography (Clarke and Morris, 1976) and ADP-Sepharose affinity chromatography (Lee et al. $\therefore$ 1976). 
The Fi Fo complex. unlike the solubilized $F_{1}$ portion. is sensitive to Inhibition by $\operatorname{DCCD}$ (N,N'-dicycolhexy carbodimide). This chemical is, therefore, used to check for the integrity of the ATPase complex during the puritication procedure (Downle et al., 1979). It is often necessary to add phospholipids to the ATPase complex to obtain maximal ATPase activity and DCCD sensitivity (Hare, $-19751$

\subsection{T. Molecular Weights ut Fl-ATPases}

The earliest measurement of the molecular weight of an Fi-ATPase was made in strep, iaecalis. Using rate-zonal sedimentation of a semipurified enzyme preparation in a density, gradient, Abrams (1965) found the weight of this enzyme to be 350,000 daltons. A more precise value of the molecular weight was determined by Schnebli and Abrams (1969) and found to be $385,000 \pm 9,000$. To date the reported values for the molecular weights of the purified $F_{1}$ from bacterial membranes ranges from 250,000 to 400,000 daltons (Downie et al. 1979).

\subsubsection{Electron Microscopic Studies on F,-ATPases}

Negatively stained electron micrographs of the membranes from mitochondria (Kagawa and Racker, 1966; Hinkle 
and Mclarty, 1978), chloroplasts (Lien and Racker, 1971; Garber and Steponkus, 1974), E. celi (Hinkle and McCarty, 1978 ), M. Lysodeikticus (Munoz, et al. , 1968), and the thermophilıc bacterıum PS3 (Kagawa et ast., 1976) all show spheres or doughnut-like structures of 8 to $10 \mathrm{~nm}$ in drameter attached to the membrane through a portion called the stalk. The $F_{1}$ from the thermophilic bacterium PS 3 has been crystallized and exhibits a periodic array of the molecules when viewed with the electron microscope (Kawaga et a 1., 1976: Wakabayashi et a. ., 1977). Image analysis.or this ti portion of the enzyme, by light diffraction, showed considerable six-told and three-fold symmetry and a hexagonal structure with a low-density region, or hole, near the center of the structure (Wakabayashi et al., 1977)

\subsubsection{Subunit Compesition and Arrangement of $F_{1}$-ATPases}

- Early analyses of $F_{1}$ preparations suggested the preserice of only two subunits (Downie et al., 1979). However, it is now generally believed that most bacterial. Fı-ATPases have at least five, subunits (alpha, beta, ganima. delta and epsiton in order of decreasing molecular woight, (Futai and Kanazawa, 1980). The molecular weights reported 
for these subunits from $\mathrm{E}$ cols tall within the following ranges: alpha, 54.000 to 00.0 bo daltóns (Kobayashi and Anraku. 1972: Hanson and Kennedy, 1973); beta, 52,000 to. 56.000 daltons (Vogel and Steinhart, 1976; Bragg and Hou, 1975; Hanson and Kennedy, 1973); gamma, 32,000, to 35.000 daltons (Vogel and Steinhart, 1976; Brags and Hou, 1975; " Hanson and Kennedy, 1973): delta, approximately $21,000^{\circ}$ daltons, Vogel and Steinhart, 1976; Bragg and Hou, 1975): epsilon, 11.00 to 13,000 daltons (Hanson and Kennedy, 1973; Bragg and fiou, 1975 ). Fl preparations with ilve subunits have beèn described tor strep iaecabis labrams et al.. 1976 ), S. typhimurium (Brage and Hou, 1975), R. rubrum (Johansson and Baltscheffsky, 1975; Lucke and Klemme, 1976), 1. phlei (Kalra et al., 1975), A. faecalis (Adólfsen et al., 1975; Adolfsen and Moudrianakis, 1976), and $\mathcal{M}$ Lysodeikticus (Huberman and Salton, 1979). It has recently been shown that not all Fi-ATEases possess the typical five subunit profile. The $F_{1}$ purified from $\underline{c}$. thermeaceticum has tour subunits with molecular. welghts corresponding to $60,000,55,000$, 37,000 , and 17,000 daltons in an apparent molar ratio of $3: 3: 1: 1$ (Mack Irey and Ljungdahl, 1986). The $F_{1}$ of Le casei has a single subunit (Biketor et al., 1982; Tikhonova et ab., $1983 ;$ and the enzyme of . . pasteurlapum possessess possibly two subunit types (Clarke and Morris, 1976.). 
The stolchiometry of the different suburits in the I ive subunit type enzymes is still unclear, and may be of the tollowing order, alphas, betas, gammal, deltal, epsilons (Bragg and Hou, 1975) or alphaz, betaz; gammaz, deltai - 2 and epsilone (Vogel and Steinhart, 1975).

\subsubsection{Actzvation of the Fi-ATPase}

Bacterial $F_{1}$-ATFases are activated by cations. Mgc+ is usually a major activator of these enzymes. however. $\mathrm{Sa}^{2+}, \mathrm{Mn}^{2}, \mathrm{Zn^{2 } +}, \mathrm{Co}+$, and $\mathrm{Cd}^{2+}$ have, also been tound to activate these molecules in a minor way iAbrams and Smith, 1974). Munoz and Salton (1968) found that $\mathrm{Ca}^{2}+$ was the main cationlc activator of the $F_{1}$ of $M$. Lysodeikticus and this activity was inhibited when $\mathrm{la}^{2}+$ was added:

The solubilized $F_{1}$ portion. of the ATPase' from $M$. phlei is inactive or latent in the hydrolysis of ATF and can be activated by trofatment with trypsin (Kalra et a... 1975). Activation by proteases has resulted in the neoessity. of the inclusion of protease inhibitors during the extraction and purification steps of these enzymes (Abrams and Smith. 29741 . 


\subsubsection{Substrates of F1-ATPases}

The Fl ATPases of bacteria are generally able $t_{1}$ hydrolyse nuclotide substratos other than ATP. They show activity. with GTP and to a lesser extent with UTE and CTF The $F_{1}$ of $B$. megaterium exhibits active hydrolysis of ITE (Mirsky and Barlow, 1971). The E. colj enzyme degrades IT and $A D F$ (Davies and Brage. 1972: Hanson and kennedy. 19731. and strep. Haecalis $F_{1}$ hydrolysed ITF and deoxyATt Marams and Smith. 1974 ).

1.5.12. Inhibition of $E_{1}$-ATPases

Unlike the FlFo complex. the soluble Fl eneyme is cold labile (i.e., activity is rapidly lost after storago at $U$ to $40 \mathrm{C}$ (Haddock and Jones; 1977). This property is shared with mitochondrial Fl (Penefsky and Warner, 1965), but not with the purified ATPases from PS3 and Mi phlei (Haukimi et a 1. 1974; Haddock and Jones, 1977)..

A number of chemical inhibitors affect the ATíases of procaryotic microorganisms. DCCD Inhibits the ATPase activity of membrape-bound, but not of soluble Fi (Clarke and Momeis, 1976; Harold st al., 1969; Bragg and Hou, 1975). This inhibitor has been shown to regct with the Fo portion of the ATPase (Abrams and Baron, 1970; Abrams et at: 1972) 
Bathophenanthroline inhibits the membrane-bound ATPase of E colj but not the soluble $F_{1}$ and $c$ an be reversed by the CicP (carbonyl cyanide m-chlorophenylhydrazone) which is-an uncoupler (Sun et al. 1975). Uncoupler sensitive inhibition of soluble mitochondrial $F_{1}$ has also been observed (Phelps et al , 1975). Oligomycin inhibits the membrane bound F1. from mitochondria. but does not affect the AT'ase activities of most of the bacteria studied to date (Downie et al. 1979). The membrane-bound ATPases of $R$. rubrum and Rhodopseudomonas sapsuldta are inhibited by oilgomycin (Downie et al., 1979).

Inhibitors that affect the solubilized ATPase (F1) activity of bacteria are azide (Munioz, et al., 1968: Evans. 1969), the antibiotic dio-9(Harold et.al., 1969: Bragg and Hou, 1975), quercetin (Futai et al., 1974), and, the zinc chelator Zincon (Sun et al. , 1975). Aurore:iin also inhibits soluble ATPase activity in bacteria (Adolisen and... Moudrianakis, 1976), but unlike its binding to mitochondrial Fi it does not show fluorescence (Van De, Stadt et al. 19741 
1.6. Goats

The purpose of this study was an examination of the polar membrane of $\mathcal{C}$ jejunj to: (i) further elaburatg on its ultrastructure from that described by Ritchie et al. (1966). (ii) to analyse minicell formation with the hope of using this fraction to obtain cytoplasmic membrane enriched in the polar membrane structure, and (iii) to determine the function of this structure.

It was recognized that the the component units of polar membrane, the stalks and knobs, were structurally similar to the ATPases of the inner mitochondrial membrane and the cytoplasmic membrane of various bacterial spocies (Racker, 1967: Harold, 1972). Therefore, a study of ATFas' activity in $\dot{q}$. jejuni was undertaken to clarify the nature and suggest the function of this interesting struature.

Since other bacteria possess polar membrane a study of the relationship between these structures was also initiated, along with a comparison of the relatedness of the ATPase of $\boldsymbol{C}$. jefuni to that of other organisms. 


\section{CHAETER 2}

\section{Materials and Methods}

\section{1 - Organisms}

The polar membrane and F1-ATFase of Campylobacter jejuni a clinical isolate obtained from Victoria Hospital London. Ontario (University of Western Ontario Culture Collection no. 1210) was examined in this study Aquaspiriblum serpens MW5 (U.W.O. no. 377 ) and A. serpens MWLi (U.W.O. no. 374) were used for structural comparisons of the polar membrane with $\mathrm{C}$. jejuri. The following organisms were used for comparison of ATPase activity by histochemical staining i) Escherichla coli K12 (U.W.O. no. 1025), ii, A. Serpens MW5, iii) Micrococeus Luteus 1U.W.O. no. 286. a "lysodeikticus" strain), iv) Deinococcus radiodurans (U.W.O. no. 1071) and v) Bacillus cereus (U.W.O. no. 317). The following organisms were used for comparisons of Fi-ATPases by immunoblotting il E celi K12, it) A serpens MW, iii) Spirillum volutans (Anerican Type.culture Collection no. 19554). iv) Vibirie choierae. CA401 (biotype El Tor, serotype INABA) (provided by T.J. Beveridge, Dept. Microbiology, Untr. Guelph. Guélph. Ontario). v) Methanececcus veltae strain PS (obtained from K. Jarrell, Queens Univ., Kingston, Ontario), and vi) rat liver mitochondria (providedfoy G. McDougall, Dept. 
Biochem. Univ. Western Ontario. London, Ontariol

2.1.1. Coutivation and Harvesting

- c. jejuni was cultivated in $500 \mathrm{ml}$ volumes of Brucella Broth (Difco Laboratories, Detroit. Mich.!. without shaking, at $40 \circ \mathrm{C}$. A growth curve for this organism was prepared by removing $1 \mathrm{ml}$ samples at various time intervals post-inoculation and measuring absorbance at $675 \mathrm{~nm}$. Alternately, for the production of minicolls. this organism was grown on Brain Heart Intusion Agar (Ditico Laboratories, Detroit, Mich.) at $400 \mathrm{C}$ in an anaerobic jar from which the atmosphere had been removed by a vacuum.

A. serpens MW5 and MW11 were grown on peptone-succinate salts slants (PSS broth containing 1 bi, - (wt/vol) agar) at $300 \mathrm{C}$ (Hylemon, et al. 1973). 'The FSS. broth, pH 7.2, contained, as a final concentration. (wt/vol): $1.0 \%$ peptone (E/fco Laboratories, Detroit, Mich.), $0.1 \%$ succinate, $0.1 \%$ magnesium sulphate, $0.1 \%$ ammonium sulphate, $0.0002 \%$ ferric chloride, and $0.0002 \%$ manganese chloride. The succinate and salts were all obtained from Fisher Scientific Co., Fair Lawn, New Jersey: After autoclaving, sterile calcium chloride was added to a final concentration of $0.025 \%$ (wt/vol).

E. coli K1,2 was grown in nutrient broth (Difico Laboratories. Detroit, Mich.) at $370 \mathrm{C}$ with shaking (J 50 
rpm: Psychrotherm incubator-shaker: New Brunswick Scientitic Co.. Now Brunswiek, N.J.).

M. Luteus and D. radiodurans were grown at $300 \mathrm{C}$ on tryptone-yeast extract-glucose agar slants, $\mathrm{pH}$ 7.U. with the final concentrations ( $w$ tyol) of the constituents; $0.5 \%$ tryptone, $0.3 \%$ yeast extract, $0.1 \%$ glucose, and $15 \%$ agar. The tryptone, yeast extract and agar were obtained from Difico Laboratories. Detroit. Mick, and the glucose from the McArthur Chemical lo.. Montreal, Can.

S. volutans was grown at $300 \mathrm{C}$ in MPSS broth. which contained $1.0 \mathrm{~g} / 1$ (NH4)2SO4 (McArthur Chem. Co..

- Montreal, Can.), 1.0 gl MgSO4.7HzO (Fisher Sci. Co.. Fair Lawn, N.J.), $0.002 \mathrm{~g} / 1$ FeSO4. 7H2O (J.T. Baker Chemical Co.. Phillipsburg. N.J.'), 5 g/l peptone (Difico Laboratories. Detroit, Mich.), $1.0 \mathrm{~g} / 1$ succinic acid (Fisher Sci. Co.. Fairlawn, N.J.), $0.0002 \cdot 8 / 1 \mathrm{MnSO} \cdot \mathrm{H} 2 \mathrm{O}$ (Fisher Sci. Co., Fair Lawn, N.j.) and adjusted to pH 6.8 with $2 \mathrm{~N}$ KOH (Fisher Sci. Co.. Fair Lawn, N.J.).

Y. cholerae CA401 was grown at $300 \mathrm{C}$ on Brain Heart Infusion Agar slants (Difico Laboratories, Detroit, Mich).

B. cereus was grown on trypticase soy agar slants (Difco Laboratories, Detroit. Mich.) at $370 \mathrm{C}$.

Methanecoccus veltae was obtained in $10^{\circ} \mathrm{ml}$ volimes of Balch medium III (Balch and Wolfe, 1979) in sealed 
serum bottles with a gas atmosphere of $\mathrm{CO}_{2} / \mathrm{Hz} \quad(1: 4$, vol/vol). The cells were harvested by centrifugation at $3,500 \times g$ for $10 \mathrm{~min}$. at $40 \mathrm{t}$. and ifozen as packed cells at $-700 \mathrm{C}$ until used for immuroblotting.

Cells were routznely harvested in the mid-logarithmic phase of growth by centrifugation at 3.500 $x$ f for $15 \mathrm{~min}$. at $4 \circ \mathrm{C}$ and washed in $50 \mathrm{mM}$ HEPES $\left(N-2-h y d r o x y e t h y l p i p e r a z i n e-\mathbb{N}^{\prime}-2\right.$-ethanesulfonic acid) bufter at $\mathrm{pH} 7.2$ containing $10 \mathrm{mM} \mathrm{MgCla}$ (HEPES-Mg ${ }^{2+-b u f f e r) . ~ U r g a n i s m s ~ g r o w n ~ o n ~ a g a r ~ s l a n t s ~ o r ~}$ plates were washed off using the aforementioned butter and centrifuged as above.

Examination of $\mathrm{C}$. jejuni cultures for minicell formation was performed as follows: samples ( $5 \mathrm{~mL}$ ) were collected at $27,30,33,37$, and $48 \mathrm{~h}$ after inoculation. mixed with an equal volume of glutaraldehyde-acrolein Iixative (Burdett and Murray, 1974) for $3 \mathrm{~h}$ at room temperature, harvested by centrifugation at $5,000 \times 8$ tor $b$ mín. at $40 \mathrm{C}$, washed 3 times in $5 \mathrm{ml}$ volumes of $0.05 \mathrm{M}$ sodium cacodylate buffer, $\mathrm{pH} .7,5$, and enrgbed in $2 x$ (wt/vol) Noble agar (Difco Laboratories, Detroit, Mich.) for embedding and sectioning.

\subsubsection{Preparatsom ef Celd Envelopes}

Envelopes were prepared as follows. Washed cells 
were homogenized with a Potter-Eivehjem tissue homogenizer using a Tefion pestle in order to remove their flagella. The homogenized cells were then centrifuged at $3.5000 \times 8$ for $10 \mathrm{~min}$ at $4 \circ \mathrm{C}$ and the supernatant fraction was discarded. The cell pellets were resuspended in ice cold HEPES-Mgf + bufter containing $10 \mathrm{ug} / \mathrm{ml}$ DNase and $20 \mathrm{ug} / \mathrm{ml}$ RNase. Both enzymes were obtained from the Sigma Chemical Co. (St. Louis. Mo.). The cells were then broken by passage through a French pressure cell (Aminco) at 16.400 lb/in". Whole cells and debris were removed by centrifugation at $3,500 \times 8$ for $10 \mathrm{~min}$. at $40 \mathrm{C}$. The supernatant was then centrifuged at $120,000 \times \mathrm{g}$ for $1 \mathrm{~h}$ at $40 \mathrm{C}$ in a $\mathrm{Ti}-50$ rotor on a Beckman L-8 ultra centrifige. The cell envelopes were then washed twice in FEFES-Mg ${ }^{2}$. buffer by homogenization with a tissue homogenizer and Tetion pestle, and centrifuged at $120,000 \times 8$ for $1 \mathrm{~h}$ each d $4 \circ \mathrm{C}$.

\subsection{Electron Microscepy}

2. 2.1. Negative Staining

Whole cells or minicells were negatively stained after adhering cells to formvar/carbon coated 200 mesh copper grids by flloating the arids on droplets of the samples on a parafin film. Excess, fluid was removed by 
touching the grids edgewise to a piece of filter paper.

The adherent cells were then washed by floating the grids successively on 5 drops of glass distilled water, stained by floating the gitids on a drop of $1 \%$ (wt/vol) aqueous uranyl acetate (Merck. Rahway, N.J.), and dried after removal of the excess stain with filter paper as above. . Membrane preparation and purified ATPase were stained as above except ho washing of the grids was performed and 1 to (wt/vol) phosphotungstic acid pHb.8 was used as the stain.

\subsubsection{Fixation, Embedding, and Sectioning}

Whole cells and minicells were routinely. $t$ ixed in $5.0 \%$ acrolein-0.25\% glutaraldehyde (both from Polysciences Inc., Warrington, Pa.) in $0.05 \mathrm{M}$ sodium cacodylate butiter at $\mathrm{pH} 7.2$, at room temperature for $3 \mathrm{~h}$ (Burdett and Murray, 1974). The cells were post-fixed,with $1 \%$ osmium tetroxide in $0.05 \mathrm{M}$ sodium cacodylate buffer for $1 \mathrm{~h}$ at room temperature, washed 3 times in the same buffer, enroved in 2\% Noble agar (Difico Laboratories, Detroit, Mich), cut into $2 \mathrm{~mm}$ blocks and stained with $1 \%$ uranyl acetate (British Drug Houses) in distilled water for. $2 \mathrm{~h}$ at room temperature. The samples were dehydrated in a 30 to $100 \%$ (vol/vol) ethanol series and embedded in Spurr embedding. medium (Marivac Ltd., Halifax, N:S., Can.). Sections wart . cut using a Porter-Blum ultramicrotome (Sorval. Norwalk. 
joinn. with glass krives. picked up on 400 mesh formvar :arbon coated copper grids and stained for 3 min with $1:$ ' wt., vol, aqueous uranyl acetate and for 6 min. with lead citrate (Reynoids, 1963). Samples were examined in 3 Hhillips EM-300 electron microscope operating at $60 \mathrm{KV}$. Micrographs, were taken on Kodak ine-grain positive $f i l n$. Some membrane preparations for embedding were prefixed with $0.5 \%$ tannic acid in $0.05 \mathrm{~m}$ sodium cacodylate. butier pH 7.2 prior to fixation with $5 \%$ acrolein-u. $25 \%$ glutaraldehydo.

2.3. Visualization of Polar Membrane on Membrane Vesicles by Negative Staining

2.3.1. Stabilization of Polar Membrane on Membrane Vesicles

Polar membrane was stabilized on the membranes by preparing the membranes as described in section 2.1 .2 ,

- excent all buffers used containéd $10 \mathrm{mM} \mathrm{MgClz}$ and $2.5 \mathrm{mM}$ 2-mercaptoethanol. The cell membranes were washed only once prior to negative staining:

2.3.L. Preparation of Lipid-Depleted Membrane sheets Cell membranes were prépared as described above (section 2.1 .2 ) and the 1 ipids were extracted from the 
membranes with ix (wt/vol) cholic acid (Sigma) according to the method of Salton et al. (1968). The extraction buffer was $20 \mathrm{mM}$ Tris-HCl, $\mathrm{pH} 7.5$, plus $1 \%$ cholic acid, 10 $\mathrm{mM} \mathrm{MgCl}$ and $2.5 \mathrm{mM} \mathcal{L}$-mercaptoethanoi. The cell membranes were extracted a total of 6 times with the cholic acid. washed twice in the same butfer minus the chollc acid and negatively stained with $1 \%$ phosphotungstic acid, pH 6.8 .

2.3.3. Application of a Medified Cell Monolayer Techniquo of Nermut (1983) for Visualizing the Inner jurtace of the Plasma Membrane

Whole cells of $C$. jejuni were harvested, washed and resuspended to a paste like consistancy. The cell paste was spread on a piece of freshly cleaved mica $(\cdot 1 \times 2 \mathrm{~cm})$. Six 200 mesh formar carbon-coated copper grids were placed on top of the cell paste, sandwiched with a piece of filter paper (Whatman no. $1,1.3 \times 2.3 \mathrm{~cm}$ ) and 1 mmersed in Tiquid nitrogen for 5 minutes. The mica and filter paper were then torn apart (under the liquid nitrogen, and the grids adhering to the filter paper were stained immediately with $1 \%$ phosphotungstic acid, $\mathrm{pH} 6.8$, to visualize the inner surface of the plasma membrane. 
2.4. Separation of Minicells frem Whole cells by Sucrese Density Centrifugation

Cultures $(24 \mathrm{~h})$ of $\mathcal{C}$. jejuni grown on Brain Heart Intusionagar plates, in an anaérobic jar under a vacuum. were harvested by washing the cells irom the plates with cold glass distilled water ( $500 \mathrm{ml}$ total valume). The cell suspensions were washed twice in cold distilled water and then layered on $10 \mathrm{ml}$ of a 1.44 M sucrose solution $1 \mathrm{n} 15$ $\mathrm{ml}$ Corex centrifuge tubes and centryfuged at $40.000 \times \mathrm{g}$ for. $1 \mathrm{~h}$ at $40 \mathrm{C}$. Whole ceils pelleted to the bottom of the tube and a diffuse band was seen at the water-sucrose interface. This band was removed, diluted $1: 3$ with distilled water and centrifuged at $40,00 / \times$ f for $1 \mathrm{~h}$. A small pellet was recovered and washed in distilled water. A sample of thes pellet was negatively stained for electron microscopic, examination and the remainder was Iixed and emberided as described in section 2.2.2.

This procedure was repeated with the inclusion of 10 $\mathrm{ug} / \mathrm{m} / \mathrm{L}$ Dase, $20 \mathrm{ug} / \mathrm{ml}$ RNase and $10 \mathrm{mM} \mathrm{MgCl}$ in distilled water.

When this procedure was scaled up, using cells grown in 500 volumes of Brucella broth and washed in distilled water containing DNase and RNase, an $0.1 \mathrm{~g}$ (wot weight) sample enriched. in minicellis was obtained from $10 \mathrm{~g}$ (wet weight, of whole cells. 
2.5. Extraction and Purification of ATPasepreon $c$ jejuni

2.5.1. Shock-Wash Procedure

Extraction of the ATPase from $\underline{\underline{C}}$. Jejuni was done according to the method of Vogel and Steinhart (1976). Fifty grams of cells (wet weight) were used for the extraction procedure. Cell membrane $0_{\text {were }}$ prepared as described previously. The membrane pellets were washed once by resuspending in $300 \mathrm{ml}$ of a 1 ThIS-HCl, pH 8.0. bufier contalning, 2. 5 . mM 2-mercaptoethanol., 1U*, (vol/vol) glycerol and $0.5 \mathrm{mM}$ EDTA. Extractions were also done using the above buffer without the EDTA fand others included the protease inhibitor phenylmețylsulfonyl fluoride (PMSE) at a concentration of $1 \mathrm{mM}$. Membranes.were collected by - centrifugation at $120.000 \times \mathrm{g}$ ior $90 \mathrm{~min}$. at $40 \mathrm{C}$. The first wash supernatant fraction was examined for ATP hydrolysing proteins after precipitation whth polyethylene glycol as described-later in this section. The washed membranes were homolenized in $600 \mathrm{ml}$ of the washing buffer. described above and incubated with stirring for $1 \mathrm{~h}$ at room temperature. This solution was then centrifuged at $120,000^{\circ} \times$ for 90 minutes. The wathed or ATPase depleted membrane pellets were resuspended in $20 \mathrm{ml}$ of $50 \mathrm{mM}$ HEPES-MgCl2 buffer and sțored at $-700 \mathrm{C}$. The supernatant 
iraction, containing the released ATPase, was mixed with methanol (4:1) and brought to $50 \mathrm{mM} \mathrm{MgClz}$ by the addition ut 1 MgCl2. The resulting precipitate was removed by centrifugation at $10,000 \times g$ for 20 minutes. To each 100 $\mathrm{ml}$ of supernatant $25 \mathrm{ml}$ of $50 \%$ (wt/wt), aqueous

polyethylene glycol (PEG) (average molecular weight 8.000 ) (Fisher Sci. Co.. Farr Lawn, N.J..) was added slowly beneath the surfiace while the mixture was stirred This solution was stirred for a turther $: 0 \mathrm{~min}$. and centrituged Ior su min: at $10.000 \times \mathrm{s}$.

The supernatant iraction was discarded and the precipltate was resuspended in $50 \mathrm{ml}$ of $50 \mathrm{~mm}$ HEFES. pH i.0, containing $20 \%$ (vol/vol) methanol, $2.5 \mathrm{mM}$ 2-mercaptoethanol and for some experiments $1 \mathrm{mM}$ PMSF. MgCl2 was added to $50 \mathrm{mM}$ and the resulting precipitate was removed by centrifugation at $40,000 \times$ g for 10 minutes. A

- .2.5 mlvolume of $50 \%$ (wt/wt) aqueous BEG (average molecular weight 1000 (British Drug Houses)) was added to each $10 \mathrm{~mL}$ $:-$. of the supernatant fraotion. The precipitated protein was collected by centrifugation at $40.000 \times g$ for $15 \mathrm{~min}$. and digsolved in $5 \mathrm{ml}$ of 50 . $\mathrm{mM}$ HEPES (pH 7.0 ) buffer containing $20 \%$ ( $\mathrm{vol} / \mathrm{vol}$ ) methanol or $10 \%(\mathrm{Vol} / \mathrm{vol}$ ) glycerol and $2.5 \mathrm{mM} 2$-mercaptoethanol and centrifuged at $10,000 \times g$ for $10, \mathrm{~min}$. to remove any undissolved material. The resulting supernatant was a clear. 'slightly yellow 
solution "This solution was applied to a column of Septiarose $6 B(2.6 \times 100 \mathrm{~cm})$ previously equilibrated with the above buffer. The protein was eluted at a flow rate of approximately $15 \mathrm{ml} / \mathrm{h}$ and $5 \mathrm{mi}$ fractions were collected. The eluted protein was detected by reading. absorbance of the fractions at $280 \mathrm{~nm}$. A single protein peak was observed after an elution volume of about $300 \mathrm{ml}$ This peak was pooled and the protein was precipifatod by addition of MgCliz to $50 \mathrm{mM}$ and $25 \mathrm{mi}$ of $50 \%$ (wt/wt) aqueous' FEG lavg.'Mr 8000 ) per $10 \mathrm{ml}$ of the protein solution The precipitated protein was collected uy centrifugation at $\mathbf{4 0 . 0 0 0 \times B}$ ior $15 \mathrm{~min}$. and dissolved $1 \mathrm{n}$ $3 \mathrm{ml}$ of $30 \mathrm{mM}$ Tris-HCl (Tris(hydroxymethyl) aminomethane 2 hydrochloride, Fisher Sci. Co.. fair Lawn, N.J.J, pH $\rightarrow 0$. containing $20 \%$ methanol and $2.5 \mathrm{mM} 2$-mercaptioethanol. This extraction and purification procedure resulted in enzyme iractions containing 1 to $3 \mathrm{mg}$ protein/ml is determined by the modified Lowry method of Hess et al. (b978): These protein fractions were analysed for ATPase activity, homogenity and subunit composition as discribed later in this chapter.

This method was also used for the extraction of the ATPase from E. coli K12. However, instead of chromatography on Sepharose 6B, trie enzyme was partially purified by affinity chromatography on ADP-Sopharose $4 B$ according the method of Higashi, et al. $\$ 1975$ ). 


\subsubsection{Extraction with n-Butanel}

The ATPase from $\mathcal{G}$. Lejuni was also extracted using n-butanol according to the method of Salton, and Schor (1974). Cell membranes were prepared as previously described. The membranes were washed and resuspended in $30 \mathrm{mM}$ Tris-HCl buffer, $\mathrm{pH} 7.5$, plus $5 \mathrm{mM}$ EDTA. The membranes were then collected by centrifugation at 120,000 $x$ g tor $90 \mathrm{~min}$, resuspended in the same buffer to give approximately $5 \mathrm{mg}$ membrane protein per $\mathrm{ml}$ and extracted at Uul by mixing with lce-cold n-butanol (Fisher sci. Co.. Fair Lawn. N.J.). Three volumes of $n$-butanol were added. with stirring, to 4 volumes of-the membrane suspension. This solution was allowed to stand for $15 \mathrm{~min}$. in an ice bath. The organic solvent phase was then separated by centrifugation:at $27,000 \times g$ for $15 \mathrm{~min}$ at $-40 \mathrm{C}$. The clear upper n-butanol layer was removed and discarded. This extraction process was repeated seven times with. tresh ice-cold $n$-butanol. The final upper $n$-butanol phase was removed and the aqueous phase above the pellet was carefully withdrawn and placed in $\dot{a}$ dialysis bag and dialysed agannst 6 changes ( $500 \mathrm{ml}$ each) of ice-cold $5 \mathrm{mM}$ Tris-HCL buffer, $\mathrm{pH} 7.5$, to remove any remaining butanol dissolved in the aqueous phase. Dialysis was continued at 40C until the preparation was of the odour of butanol. The dialysed aqueous phase was then centrifuged 
at $27,000 \times$ for $30 \mathrm{~min}$. at $00 \mathrm{C}$ and the supernatant was concentrated in an Amicon ultrafiltration apparatus Imicon Corp.) iftted with a PM10 membrane filter. The concentrated supernatan't was then centrifuged at $120,000 x$ 8 for $90 \mathrm{~min}$. at $40 \mathrm{C}$. The pellets were discarded and the supernatants were further concentrated by ultrafiltration

- The final protein concentration of the supernatnat was estimated to be $3 \mathrm{mg} / \mathrm{ml}$ by the modified Lowry method ut Hess et al. (1978). This fraction was dialysed against 30 mil Tris-HCl buffer, pH 7.5 , and $0.35 \mathrm{~g} / \mathrm{ml}$ of solid ammonium sulphate was added with stirring at vol. The pH of the solution was adjusted to 7.2 with the addition of 1 $\mathrm{MNaOH}$ and the suspension was held at 0oC for $1 \mathrm{~h}$. The precipitated protein was collected by centrifugation at $10.000 \times \mathrm{g}$ for 20 minutes. The pellet was respispendad in 2 $m 1$ of Tris-HCl buffer, $\mathrm{pH} 7.5$, and centrituged al 27, vull $x$ g for $30 \mathrm{~min}$. to remove any insoluble material. "The supernatant was then dialysed against $30 \mathrm{~mm}$ Tris-fil: buffer,'pH 7.5, and applied to a Sepharose 6B eolumn 12.6 - $x 100 \mathrm{~cm}$ ) previously equilibrated in the same butier. A. protein peak was observed after an elution volume of approximately 320ml: This peak was concentrater by ultrafiltration as previously described and had a protein concentration of approximately $1.5 \mathrm{mg} / \mathrm{ml}$. This firaction was then analysed for ATPase activity, homogenity and subunit composition as described later in titis chapter. 
$\therefore$ b. Dentermination of Frotein

Protein coricentrations were determined bsa the

modified Lowry method of Hess, et a 1 (1978). Bovine

serum albumin (Sigma) was used as a standard

i.7. Electrophorsesis and Molecular Weight.

Detẹrminations

Polyacrylamide Bel electrophoresis under

non-dissociating conditions was carried out on $5 \%$

polyacrylamide ( $30: 0.8$; acrylamide:bis-acrylamide)

discontinuous slab gels, with a $3 \%$ stacking gel, using

the rethod of Laemmli (1970) as described by Koval and

Murray (1981) without sodium dodecyl sulphate. Protein

was detected by staining with Coomassie brilliant blue

k250 in $25 \%$ methanol and $7 \%$ acetic acid at room

temperature overnight. Destaining was accomplished by

diffusian in several changes of $25 \%$ methanol-10\% acetic acid. Samples were made in the sample, buffer described by Laeamli (1970) without sodium dodecyl sulphate, 2-mercaptoothanol or heating. All chemicals for electrophoresis were obtained from Bio-Rad Laboratories (Kichmond, Calif.). ATPase activity, in the gels, was detected by the method of Abramsi, et af. (1976). Lanes to $f$ be assayed for ATPase activity were ctit from the slab get 
and incubated in $30 \mathrm{mM}$ Tris-HCl buffer. $\mathrm{pH} 7.5$, plus 5.0 mM ATP or alternate substrates and $10 \mathrm{mM} \mathrm{MgClz}$ or alternate ions and incubated for $2 \mathrm{~h}$ at $370 \mathrm{C}$. The incubation mixture was then removed and the gels were rinsed twice with distillod water. The gels were then stained for the presence of inorganic phosphate ( $\left.F_{i}\right)$ with a mixture of $9.4 \%$ (vol/vol) perchloric acid, $1 \%$ (wt, vol.' ammonium molybdate and $0.25 \%$ (wt/vol) 1-amino-1 naphthisl-4 sultionic, acid (Fisher Sci., Co., Fair Lawn. N J.). The E. containing bands were allowed to develop to the point wher: the gel background remained clear (approximately 20 min). The stain was then removed and the gels were washed twice with distilled water, allowed to air dry for $20 \mathrm{~min}$. and photographed with Kodak Panatomic $X$ film.

Gel analysis under dissociating conditions was. carried out on $12 \%$ polyacrylamide slab gels containing $0.1 \%(w t / v o l)$ sodium dodecyl sulphate (SDS-PAGE) or $8 \mathrm{M}$ urea (Urea-PAGE) using the system of Laemmi (1970). Samples for SDS-PAGE were routinely heated in the sample butier described by Laemmli (1970) at $1000 \mathrm{C}$ for 3 minutus. SDS-PAGE gels were stained for protein with Coomassie brilliant blue as described above or by silver staining (Bio-Rad Laböratories, Rlchmond, Calif.). In some cases, in order to resolve subunit composition, tus-FAGE was carried out for twice the amount of time it touk for 
the dye front to reach the bottom of the gel. Samples for Urea-PAGE were prepared in 8 M urea plus $2.5 \mathrm{mM}$ 2-mercaptoethanol.

The molecular weight ỗ the denatured ATPase was determined by comparing its migration in SDS-polyacrylamide gels to that of RNA polymerase (165.000, 155.000, and 39.000 daltons). The molecular weights of cell proteins visualized by lmmunoblotting were determined by comparing their migrätion in SDS-polyacrylamide gels to those of the following calibration proteins: beta -galactosidase (116,000). phosphorylase B $(97,400)$, bovine serum albumin (66,000), and carbonic anhydrase (29.000) (Sigma Chẹmical Co., st. Louis. Mo.)

\subsection{Measurement ef ATPase Activity}

ATPase activity was measured at $370 \mathrm{C}$ in a reaction mixture containing $5 \mathrm{mM}$ ATP (or alternate substrate), 10 mM MgCl2 for alternate ion) in $30 \mathrm{mM} \mathrm{Tris-HCl}$ buffer (pH $7.0)$, and 50 to $100 \mathrm{ug}$ of protein in a volume of $1 \mathrm{ml}$. The reaction was initiated by add + ng ATP and stopped at various time incervals $(0,30,60,105,120,150$, and 180 min.) by the addition of 200 ul of $10 \%$ (wt/vol) trichloroacetic acid (TCA). The precipitated protein was removed by centrifugation in an Eppendort centrifuge and 
$500 \mathrm{ul}$ of the supernatant was removed for detection of inorganic phosphate by the method of Abrams et al. (1976)

$\mathrm{KH} 3 \mathrm{PO}$, was used as a standard and $P_{1}$ levels were determined by reading the absorbance at $650 \mathrm{~nm}$. $\because \quad$ One unit of activity was defined as the release of 1 $u M$ of $P_{2}$ per min.. and specific activity was defined as. the units of activity per milligram of protein. The effect of inhibitors on ATPase activity was evaluated by incubating the ATPase (soluble and membrame bound) in the assay mixture with the inhibitors at $370 \mathrm{C}$ for $10 \mathrm{~m} n$. prior to starting the reaction by addition of the

- substrate.

\subsection{Substrate specificity}

Analysis of substrate specificity of the ATPase from 6. Lejuni was done using the non-denaturing PAGE activity assay described in section $2: 2.8$. GTP. CTP. TTP. ITP.: AMP, ADP (all from Boehringer Mannheim. Dorval, Wuebec. Can.), and glycerol-6-phosphate (Sigma Chemical Co.. St. Louis. Mo.) were tested at a level of $5 \mathrm{mM}$ in $30 \mathrm{mM}$ Tris-HCl buffer, $\mathrm{pH} 7.0$, plus $10 \mathrm{mM} \mathrm{MgCl}$.

\subsection{Effect of Ions on Enzyme Actiyation}

Ionic activation of the ATPase was analysed by the non-denaturing PAGE method described earlier. All cations 
were used at a level of $10 \mathrm{mM} . \mathrm{Mg}^{2+}, \mathrm{Ca}^{2+}, \mathrm{Co}^{2+}, \mathrm{Fe}^{3+}$, $\mathrm{Zn}^{2+} \mathrm{Mn}^{2+}, \mathrm{Na}^{+}$, and $\mathrm{K}^{+}$were tested for enzyme activation. $\mathrm{Mg}^{2}+$ and $\mathrm{Ca}^{2}$ + were tested as a mixture at a level of $10 \mathrm{mM}$ each.

\subsection{1. veld Lability}

Aliquots ( $100 \mathrm{ug}$ of $2.5 \mathrm{mg}$ protein/ml) of purified ATPase irom C. jejunt were stored at $-200 \mathrm{C}$ for $U$ to $10^{-}$ days. Une sample was removed every $24 \mathrm{~h}$ and assayed for ATPase activity as described in section z.2.9.

\subsection{Effect of Inhibitors on Soluble and Membrane}

\section{Bound ATPase Activity}

N,N'-dicyclohexylcarbodiimide (DCCD) and oligomycin (both from Sigma Chemical Co., St. Louis, Mo.l. were tested for their effect on both the soluble and membrane bound ATPase from $\dot{s}$. jejund. Inhibition was evaluated by incubating $100 \mathrm{ug}$ protein $/ \mathrm{ml}$ of the soluble ATPase, or 100 us protein /ml of the washed membranes iprior to extraction) with the inhibitors (DCCD: 1.0 and 5.0 uM; oligomycin: 10 and $20 \mathrm{uM}$ ) for $10 \mathrm{~min}$ pror to the addition of ATP. The enzymes were ifrubated in the presence of ATP for $30 \mathrm{~min}$, the reaction was stopped by addition of TCA and the lovels of $P_{1}$ released were measured as described in section 2.2.9. Control samples 
containing neither inhibitor were used to estimate normal ATEase activity. This activity was considered to be 100x and inhibition was determined by a decrease in actirity from this value. DCCD was dissolved in methanol and the control sample for this agsay contained an oqual concentration of methanol.

\subsection{Effect of Trypsin on the Soluble ATRase Activity}

- Trypsin (Sigma Chemical Co., St. Louis. Mo.). at levels of $0 \$ .0 .1$, and $0.5 \mathrm{mg}$ trypsin per mg of ATPase protein', was incubated in the ATPase assay mixture described in section $2.2: 9$ for $0,5,1 \%$ and $30 \mathrm{~min}$. at $370 \mathrm{C}$. Pi released was then measured as described earlier

\subsection{Reconstitution of ATPase Activity in ATPase .}

\section{- Depleted Membranes}

Purified ATPase (200 ug protein/ml), prepared as described in section 2.5.1, was added to 400 ug protein/ml of shock-washed or ATPase depleted membranes, which had been resuspended in $30 \mathrm{mM}$ Tris-HCL buffer, pH 7.0 , plus 10 $\mathrm{mM} \mathrm{MgCl2}$, in a total assay yolume of $1.5 \mathrm{ml}$. This suspensioneroom temperature. The membranes were then collected by centrifugation for $20 \mathrm{~min}$. in an Eppendorf centrifuge and the supernatant was removed and asgayed for protein 
content and ATP̉ase activity. The membrane pellet was washed 5 times in the above butier and assayed,for protein content and ATFase activity.

2.15. Histochemical Staining for ATPase Activity Lells to be histochemically stained for ATFase localization, after the method of Voela (1964), were harvested in phosphate buffered saline (PBS) $\mathrm{pH} 7.2$ and pretixed for $10 \mathrm{~min}$. at room temperature with $1 \%$

glutaraldehyde in PBS. Alternatively the cells were prefixed if $1 \%$ formaldehyde for $20 \mathrm{~min}$ at room temperature. The fixed cells were washed 5 times in glass distilled water and resuspended in the ATP medium of Otero-Vilardibo et al. (1963) and incubated at room temperature for 20,30 , and $60 \mathrm{~min}$. The ATP medium contained in final concentrations $8.3 \times 10^{-4} \mathrm{M}$ ATP-disodium (Sigma Chemical Co.. St. Louis, Mo.), 0.08 M Tris Malate buffer $\mathrm{pH} 7.3 .2 .5 \times 10^{-3} \mathrm{MPb}(\mathrm{NO}) 2$, no

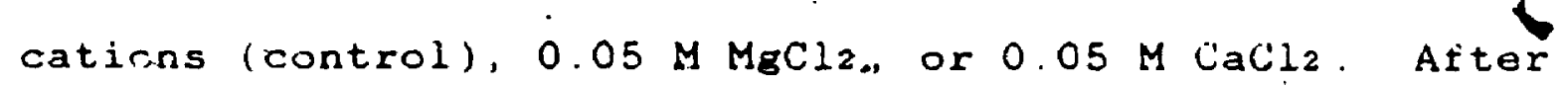
iniubarion the cells were washed 3 times in glass distilled water and resuspended in $1 \%$ osmium tetroxide for $1 \mathrm{~h}$ at room temperature, washed 3 times with biass distilled water and enrobed and embedded as described above. Tbe sections were stained with $2 \%$ uranyl acétate in $50 \%$ (vol/vol) ethanol at $600 \mathrm{C}$ for $10 \mathrm{~min}$. 
2.16. Antzgen Lecalization of ATPase in Thin Section

2.16. Anthas hecaliagtien

\subsubsection{Preparation of Antisera and Isolation of Gamma}

\section{Globulin (IGG) Eractions}

Antisera, specific for the purified ATPase isolated

from $\underline{C}$. jejunl, was raised in $2.5 \mathrm{~kg}$, New Zealand white.. . 2 r

female rabbits. A preparative non-dissociating

polyacrylamide gel was loaded with $13^{\circ} .3 \mathrm{mg}$ of the purified

proteln (prepared as described in sẹction 2.5.1) and

electrophoresis conaucted as usual. The gel was brietly

fixed. stained, and destained and the ATPase band excised.

The protein-contining gel slice was washed in saline and

then completely homogenized by, first, grinding with a mortar and pestle and then by passage through a syringes fitted with succesgively higher guage needles (18 to 26 guage). The suspension volume was then brought to $5 \mathrm{ml}$ with sterile saline and mixed $1: 1$ with Freunds complete adjuvant. Une ml (approximately i mg ATPaseiof thij antigen preparation wás then injected subcutaneously into the neck region of each rabbit. Two weoks later the rabbits were rechallenged with $1 \mathrm{ml}$ of the antigen by intramuscular injection. This procedure was repeated one week later. Five weoks following the initial injection. the blood was obtained from the rabbits by siltting the ear vein and using a mild vacuum collection apparatus. 
The blood was allowed. to clot at $4 \circ \mathrm{C}$. and the antisera was stored at -700d Normal (preimmune) serum was collected prior to injection with the antigen. Rabbit antiserum specitic for the native $F_{1}$-ATPase of $\mathbf{E} \cdot$ 'soli K12 was a Sift from Dr. S.Dunn, Dept. Of Biochemistry. University of Western Ontario, London, Canada

The IgG fractions were isolated by passing the crude antisera through a Frotein A-Sepharose column (Bio-Rad). The bound IgG was eluted in $0.5 \mathrm{ml}$ fractions with $U .1 \mathrm{M}$ glycino-Hil, pH 3.0 , into tubés containing 0.5 m 1 of $1,1 M$ Tris-HCl. $\mathrm{pH}$ 8.0. and the absorbance of the eluted fraction was measured at 280 , nm. The eluted IgG fractions were pooled and simultaneously concentrated and dialysed against $10 \mathrm{mM}$ phosphate buffered saline (PBS), pH 7.4, by Amicon ultrafiltration, using a YM30 membranefilter. The Igt samples were stored in $200 \mathrm{ul}$ aliquots at $-700 \mathrm{C}$.

2.16.2. Antiken Localization in Thin section of spurr Resin-Embedded Colls

Thin sections of whole cells fixed and embedded as described in section 2.2.2. were picked, up on naked 400 mesh nickel grids and antigen localization was carried out according to the methodsof Roth (1982). The grids with the attached thin sections were placed face down on a droplet of $1 \%$ (wt/vol) ovalbumin (Caibiochem, San Deigo. Calif.) in FSS ( $\mathrm{pH} 7.4$ ) for $5 \mathrm{~min}$. at room temperature. the grids were then transferred, without rinsing onto 
drops of the antibody solutions for 2 h at room

temperature or $18 \mathrm{~h}$ at $40 \mathrm{C}$. These procedures were carried out in a moist chamber. Various dilutions of the antibody solution (in PBS plus 1\% ovalbumin) ranging from 1:100 to 1:100.000) were used. The sections were then "jet-washed" by a mild spray of filter sterilized PBS (i.e. at ter passage through a 0.2 um millipore filter fromia plastic spray bottle. placed in PBS for about $2 \mathrm{min.}$. jet-washed" a second time with PBS and blotted by holding the grids edgewise on a piece of filter paper. The grids were then placed on drops of a 20 to 25 fold/dilution of a 5 or 10 nm protein A colloidal gold stock solution (Janssen Pharmaceutica Life Saiences Products. Beerse. Belgium) tor 30 to $60 \mathrm{~min}$ at room temperature: in a moist chamber. The grids were then "jet-washed" with PBS for 1 min.: immersed for $5 \mathrm{~min}$. in PBS in a porcelain depression dish, "jet-washed" and immersed in PBS a second time and tinally "jet-washed" with filfer,sterilized 10.2 um millipore iliter) double distilled water.' The grids were never allowed to dry during the whole procedure. Finally, the section were stained with $5 \%$ aqueous icanyl acetate and lead citrate (Reynolds, 1963) for 5 and $10 \mathrm{~min}$. respectiyely.

Controls for this method were as follows; i) FES plus 1 to ovalbumin was used in place of the antibody solition, and ii) dilúted normal pre-immune igG was used. 
in place of the antibody solution.

For some localization studies thin section of whole cells whlch had been post-fixed with osmum tetroxide were etched for $2^{-h}$ at room timperature by floating grids with the attached sections on droplets of $20 \%$ (volyol) hydrogen peroxide (Eisher Scientific Co., Fair Lawn, N.J.)

2.16 .3 Low-Temperature Embedidink for Antigen Lecalization

- Lowicryl KM4, Chemzsche werke Lowi. D8264 Waldkraiburg, F.R.G. , àn embedding resin which polymerizes at very low temperatures, was used as an. alternative to Spurr resin embedding to perserve antigen structure ior antibody: localisation in sections.

Eultures were fixed for low temperature embedding asing $5 \%$ acrolein-0.25\% glutaraldehyde in $0.05 \mathrm{M}$ sodium cacocdylate buffer ąs previously described. However. post-fixation with osmium 'tetroxide' and.block staining with $1 \dot{\phi}$ uranyl acetate was omitted. Dehydration with ethanol and embedding in Lowicrgh KM4 was done àccording to the method of Roth, et al., (1981). The iixed cells 'were enrobed in 2x Nable agarfas previously descicribed, cut into $2 \mathrm{~mm}$ blocks and denydrated in 30x (volyvol) ethanol-. at $0 \circ \mathrm{C}$ (on crushed ice) with agitation for 30 min. The. tissue blocks in the $30^{\circ}$ ethanol were then transfenred. to 
- $220 \mathrm{C}$ (Crushed ice: NaCl, $3: 1$ (wt/wt)) - and dehydiration was continued with 50x, 70x, $95 \%$ and 2 times $100 x$ ethanol solutions for $1 \mathrm{~h}$ each at.:-20.C. The tissue blocks were then transferred to a precooled $1: 1$ (vol/vol) Lowicr. KM4:100\% ethanol fer $1 \mathrm{~h}$ at $-220 \mathrm{C}$. "This was followed transfer of the blocks to a $2: 1$ solution of resin in 100t. ethanol for $2 \mathrm{~h}$ at the same temperature and finally by.

transfer to pure resin for $1 \mathrm{~h}$ at $-220 \mathrm{C}$. The tissue blocks were then placed in fresh resin and held at $-220 \mathrm{C}$.

- overnight. The resin was composed of 2.5 g of crossliriker A. $i 7.3 \mathrm{~g}$ of monomer $B$ and $0.1 \dot{8}$ of $1 \dot{n} i t i a t o r . C$. Fresh. resin was prepared, precooled to $-220 \mathrm{C}$ and placed in capped BEEM capsules leaving no air space at the top. Tfe tissue blocks were transferred to the prefilled BEEM capsales and allowed to equilibrate for 10 minutes. These steps were performed in a precooled styrofoam chest which was itted with. a long wave ultraviolet lamp in its lid. This UV chamber was kept, in a $40 \mathrm{C}$ walk in cold room. The inside. of the UV chamber was lined, with aluminum foil as a reflector. The BEEM capsules containing the tissue blocks were placed in the bottom of the UV chamber $124 \mathrm{~cm}$ irom the UV source), the chamber was cooled to. $-220 \mathrm{C}$ with a crüshed ice: $\mathrm{NaCl}, 3: 1$ mixture and curing by UV irradiatiog was carriegd out for $24 \mathrm{~h}$ at this tomperature and for $48 \mathrm{~h}$ at room temperature. The blocks were sectioned as. 
previously scribed. The sections were plcked up on naked nickel grids, incubated with antibody and protein $A$. colloidal gold $(5 \mathrm{~nm})$ as previously described and finally stained with $5 \%$ aqueous uranyl acetate for $30 \mathrm{~min}$ : at room temperature.

2.16.4. Antzgenic Relatedness of ATPase from $C$ jejlini to ATPases of other Bacterial Species and Rat Liver Mitochendria

\subsection{5 immunebletting}

$$
\therefore
$$

Whole cell suspension of $C$. jeiuni, E. celi kl2, ‥

- shelera, A., serpens MW5, S. velutans, M. voltae, and rat liver mitochondria wore prepared in glass distilled water. The protein content of each suspersion was measured by the modified Lowry, method of Hess et al. (1978) for proteins insoluble in $1 \mathrm{~N} \mathrm{NaOH.} 150$ ug protein of each cell type was electrophopresed on a $12 \%$ SDS-polyacrylamide gel and then electrophoretically transferred to nitrocellulose paper $(40 \mathrm{~V}, 3 \mathrm{~h})$ by the method of Towbin, et al. (1979).

4 The protein transferred to the nitrocellulose paper was visualized by briefly. staining ( $2 \mathrm{~min}$.) with $1 \%$ Amido blafk in $25 \%$ methalol, 10x acetic acrd and destaining in 10* methanol, 10x acetic acid. The individual lanes were cut out and washed, pirst with distilled water, then with 
PBS (pH 7.4). The nitrocellulose strips were then washed in PBS overnight at $4 \circ \mathrm{C}$. The PBS wash solutions were removed and any available non-specific antibody binding sitess were blocked by incubation of the strips in $1 \%$. (wt/vol) BSA in PBS for $2 \mathrm{~h}$ with gentle agitation. Tho strips were then washed 6 times in PBS for a period of 40 min. and incubated for $2 \mathrm{~h}$ in PBS containing either IgG prepared against the ATPase from 8 . iejuni (10 ug protein/ml), IgG prepared against the $F_{1}$-ATPase of $E$ coli K12 (10 ug protein/ml), or preimmune İG (10 ug protein/ml). The antibody solution's were then removed. the strips were washed 8 times in PBS over 1 h with gentle agitation, and ingubated for $2 \mathrm{~h}$ with goat anti-rabbit. IgG-horse radish peroxidase conjugate (Bio-Rad) (8 ug/lane). The strips were washed overnight with PBS and the bound IgG was visualized with 4-chloro-1-napthol. The strips were rinsed with distilled water, allowed to air dry; and photographed using Kodak Panatomic X film. 


\section{CHAPTER 3}

\section{RESULTS}

1 1. Growth Characteristies of C. jejuat

A growth curve for $E$. jesuni cultivated in $500 \mathrm{ml}$ volumes of Brucella broth, without shaking. at $400 \mathrm{C}$, is shown in Eigure 3. This organism' showed yery little lag in growth when a large inoculum $1100 \mathrm{ml}$ of a 24 hour culture; was used and the culture was not disturbed tor the tirst five hours of growth. The exponential phase of growth lasted approximately 15 hours and the culture entered stationary phase at approximately 20 hours post inoculation. Growth under these circumstances provided approximately 2.0 g of cells (wet welght) per $500 \mathrm{ml}$ culture:" "†

\subsection{Ultrastructure of Pelar Membrane}

3.2.i. Lecation in whole Cells

Thin section: of whole cells of $\mathrm{c}$ lejuni from a 24 hour culture showed the typical helical shape and

- structures associated with this organism (Figuro 4). A - polar flage!lum and adjacent polar membrane was visible at 
the poles of the cell underlying the plasma membrane as described by Ritchio et al. (1966). Spherical inclusion bodies, with densely rained perımeters and lighter interiors, were seen in the polar regions of the cell and appeared to be locatpd centrally whthin the region where. polar membrane was found (Figure 4). The polar regions also contained a lower concentration of ribosomes than the rest of the cytoplasm (Figure 4) similar to the observation of Murray and Bireh-Aindersen (1963) in A. serpens Figure 5 allows a comparison of the location and ultrastructure of polar membrane in A. serpens MW11. This organism possesses a polar tuft of flagella inot visible in this micrograph), polar membrane underlying the plasma membrane, ard a ribosome free area at the poles

A cross section through the polar region of $\underline{C}$ jejuni suggests that the polar membrane structure covers the entire inner surface of the plasma membrane IFigure b). whereas, a cross section through the pole of $A$ sezpens "MW5 shows the polarmembrane to be located in patches (Figure?7).

Poldr membrane has also been noted at the site of septum formation.. (Figure 8), which is" in agreement, with the observations of Murray and Birch-Andersen (1963) and. Ritchie et al. (1966). However, the location of polar 
membrane at this site is not a consistent result (Figure $9)$ as it is not known when polar-membrane is laid down at $\because$ the poles.

3.2.2. Assegiation of Relar Membrane with the Flageflar Basal Complex

The tlageliar basal complex in $\mathcal{f}$. jejuni, when dissoclated from the membranes, shows the typical four ring structure associated with Gram negative basal complexes and a Pso possesses concentric membrane rings (UMR's) between the $L$ and the $P$ rings (Ferris and Beveridge, 1984). Figures 10 through 15 are high magnification miorographs of longitudinal thin sections of the polar region of $C$. jejund. When the section passes through the centre of the basal complex it is possible to distinguish the location of the CMR's, the $P$ ring and the Mring (Figures $10,11,12$, and 13), however, an of centre cut blurrs the position of the rings within the cell envelope (Figures 14 and 15). The position of the rings observed in these micrographs and the presente of ifbres extending from the $M$ ring (Figures 10 and 11) are in agreement with the observations of Coulton and Murray (1977, 1978) and Ferris and Beyeridge (1984)." Figures 10 through 15 also illustrate the - association of polar membrane with the basal complex. 
Folar membrane encroaches on the lateral margin of the basal complex to varying degrees, as can be seen by comparing Figures 10 through 15. In Figure 10 the polar membrane structure lines the inner surface of the plasma membrane startin approximately $800 \mathrm{~nm}$ away from the basal complex. In Figure 11 the structure begins approximately $600 \mathrm{~nm}$ down the plasma membrane from the basal complex and in Figures 12 through 15 the structure can be seen next to the basal complex but not covering the area where the $M$ flng is located.

A distinct ribosome free area can be seen in Figures 10, 11, 12, 14 and 15: As well, a densely stained" inclusion body wjth an ill defined perimeter was observed in the polar region (Eigure 15 ).

\subsubsection{Eine Structure and Dimensions of Polar Membrane}

3.2.3.1 utservations on Thin Sections of $C$. jejunt Polar membrane appears, on thin section, as a densely-staining line approximately $200 \mathrm{~nm}$ internal to the plasma membrane and appears to be connected to the plasma. membrane by bands or striations (Figures 4 and 6 ).

ubstryations of this structure in $A$. serpens MW11 clearly show the presense of stalks ariding out of the plasma membrane joihed to globular structures at the apposing end 
(Figure 5). The structure in $\mathcal{G}$. Jejuni has not been as clearly resolved on thin section, but figure 16 shows a high magnification micrograph of this structure. Globular units or heads can be seen in the densely staining line $200 \mathrm{~nm}$ from the plasma membrąne and stalks joining these heads to the plasma membrane are partially resolved. The heads are approximately 5 to $6 \mathrm{~nm}$ in diameter and the stalks appear to be half this size although measurement of these structures, is hampered by the poor resolution. \&. It should also be noted that the plasma memorane in the polar membrane, region has a smoothdr almost rigid form when compared to the lateral plasma membrane (Figures 10 to 161 .

$3: 2.3 .2$. Observations by Nerative Stain on Membrane preparatiens of $\mathrm{C}$. jejunt.

Negatively: stained preparations of unwashed $\underline{\mathrm{C}}$. jejuni cell envelopes obtalned by French pressure cell disruption showed the presence of small doughinut-shaped structures on, ; the membranes associated with the flagellar basal complex. (Figure i7a). These structures corresponded in size ( 5 to $6 \mathrm{~nm}$ in diameter) and location to the globular head units soen on thin section: The'se structures were al so' observed in an intact polar vesicle (Figure 17b) further associating them with the polar membrane structure seen on. - thin section. 
These structures were not frequently seen in washed membrane preparations. Occasionally they were observed in enclosed vesicles of membrane from the polar region. recognized because of the presence of. CMR's (Figure 18),

The inclusion of $2.5 \mathrm{mM} 2$-mercaptoethanol and $10 \mathrm{mM}$ $\mathrm{MgCl}_{2}$ in the $50 \mathrm{mM} \mathrm{HEPES}$ wash buffer Increased the Irequency of observation of these structures on membrane preparations. Figure 19.a shows a membrane vesicle partiaily covered with small dough-nut shaped structures (5 to $6 \mathrm{~nm}$ in diameter) which appear to be arranged in an hexagonal pattern.

These structures were also observed when whole cells were cleaved by a modification of the monolayer technique of Nermut (1983) and the resulting membrane fragments were negatively stained (Figure 19b). This micrograph"also shows the size relationship of these sturctures to the flagellum.

When membrane preparations were washed in a high ionic strength buffer containing 2-mercaptoathanol as described previously and the membrane ilpid was'extracted with cholic acid (Salton, et al., 1968) a ifne hexagonal array was observed in the lipid depleted membranes (Figure -

- 19c and $d$ ). This array possessed repeating units of approximately $3 \mathrm{~nm}$ in diameter and may represent the 
insertion points of the stalks of the polar membfane strpcture in the plasma membrane.

These structures were not seen when the membrane preparations were $\dot{t} i x e \dot{d}$ and embedded for thin sectioning. It is possible to maintain the polar membrane structure on the plasma membrane. in crude membrane preparations, by usihg the mordant. tannıc acid. howerer. the Iine structure of $\sqrt{s t a l k s}$ and knobs is obscured (Figure 20).

3. 3. Munzceil torfation by i: jejuni

Electron microscopic examination of cells harvested at 27 through 33 hours post inoculation (stationary growth phase, showed the typical helical shape associated with $\underline{\text { S. }}$ jejunt and a normal constrictive form of cell division las shown in Eigures 4 and 9). However, among these normal * cells were a few much smaller structures $(0.1-0.3$ um in diameter) bearing flagella (Figure 21).. Thin sections of these structures showed that these minicells were bounded by outer membrane and by a plasma membrane (Figure 22). The interior contained few ribösomes and no obìious nucleoplasm. The membranes appeared to enclose these ininicells entirely and on their inside was a structure pientical to polar membrane.

Examination, by thin section, of a series of whole. cells collected at 33,37 , and 48 hours, after inoculation 


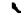

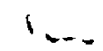

provided an increased proportion of minicells to whole cells and allowed deduction of the events involved in forming the minicells. The apparent initial event in their formation involved increasing degrees of constriction of the plasma membrane, resulting in the segregation of the polar region of the cell (Eigure 23) This constriction of the plasma membrane without constriction of the outer membrane las observed in normal cell division) was also observed by negative stain (Figure. 24\%. The profile of the peptidoglycan layer in the cell wall, expected to lie between the outer membrane and the piasma membrane, was not often seen on thin sections of

- young cells (Figure 4) and could not be located on thin sections of the segregating terminal regions of the minicells; (Figure 24). The terminal events in the

- formation of these structures were not observed.

This phenomenon commonly observed in oldercultures entering stationary phase, also occurred when younger -cultures (18-24 hours) were subjected to adverso conditions, such as atmospheric levels of oxtgen after growth on agar plated under a vacuum or resuspension of cells grown in broth in glass distilled water.

These minicells could be partially separated from the whole cells by differential centrifugation in a discontinuous sucrose gradient $(30 \%(\omega / W)$ and $60 \%(w / W))$. 
However, the quantity of the minicells harvested in reasonably pure form was too small to allow biochemical analysis and the preparations were usually contaminated, whth whole cells, flagella and membrane fragments (Figure 251. This result was probably due to the sticky nature of c. Lejuni celis and minicells, which prevented a clean isolation by gradient centrifugation, even in the presence or DNase and RNase. Figure 26 is a high magnification of a negatively stained minicell. This micrograph shows the presence of a hexagonal array within the structure similar to that obserued in lipid depleted membranes.

3.4. Eecalization of ATPase Activity in Whole Cells by Histochemical Staining

Thin sections of $\mathrm{C}$. jejuni cells prefixed with $4 \%$ $(\mathrm{v} / \mathrm{v})$ glutaraldehyde and incubated with ATP and $\mathrm{Mg}^{2+}$ cations were found to have heavy deposits of lead phosphate in the polar regions and light deposits elsewhere in the cell (Figure $27 a-d$ ). Spheroplasts of $\underline{C}$. jeiuni also showed localized deposits of lead phosphate along the inner surface of the plasma membrane (Figure 28 a and $b)$. Cells incubated with ATP and $\mathrm{Ca}^{2}+$ cations were found to have light lead phosphate deposits around the plasma membrane and the inclusion granule seen in the. polar region (Figure $29 a$ and $b$ ). 


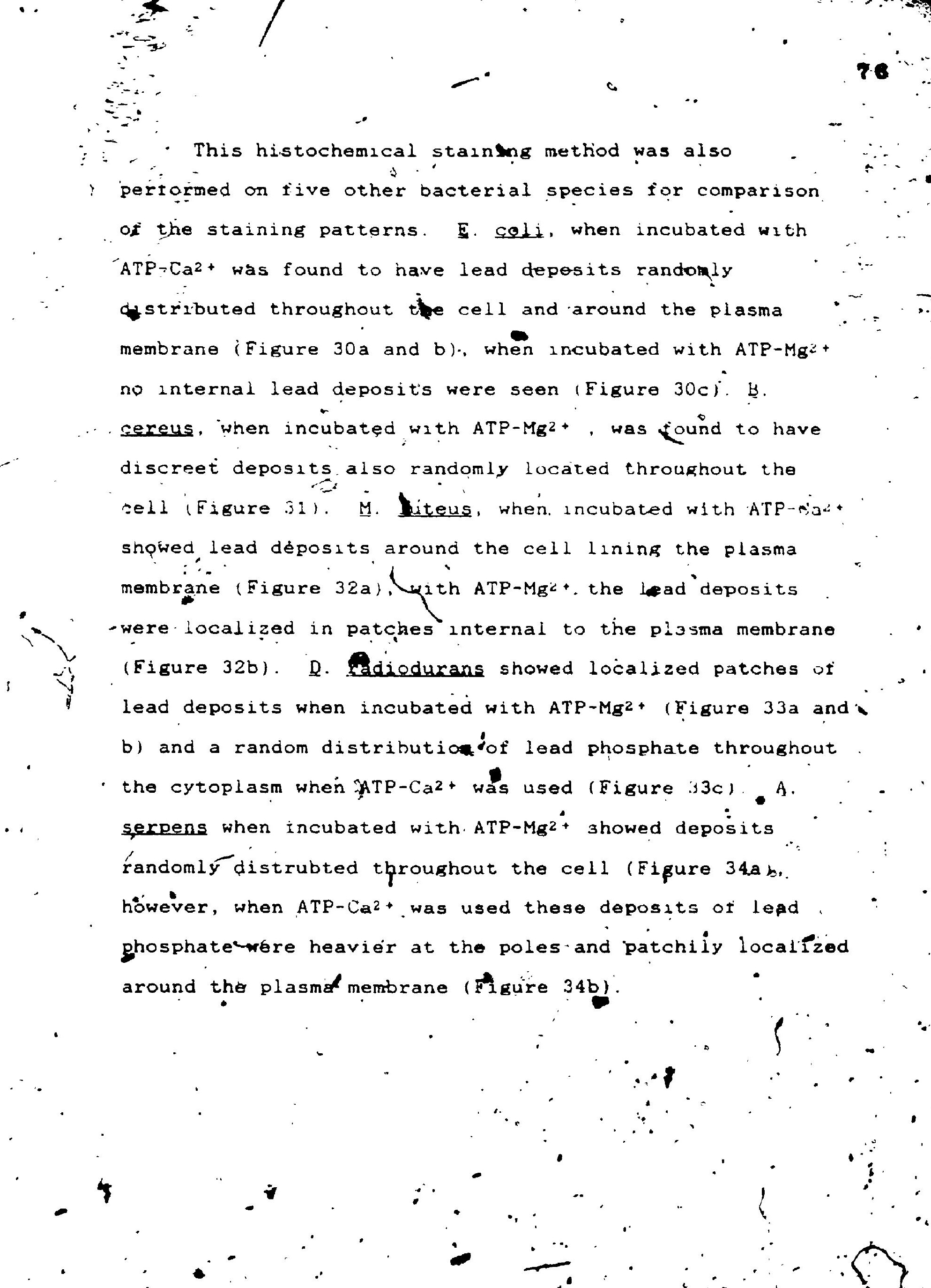




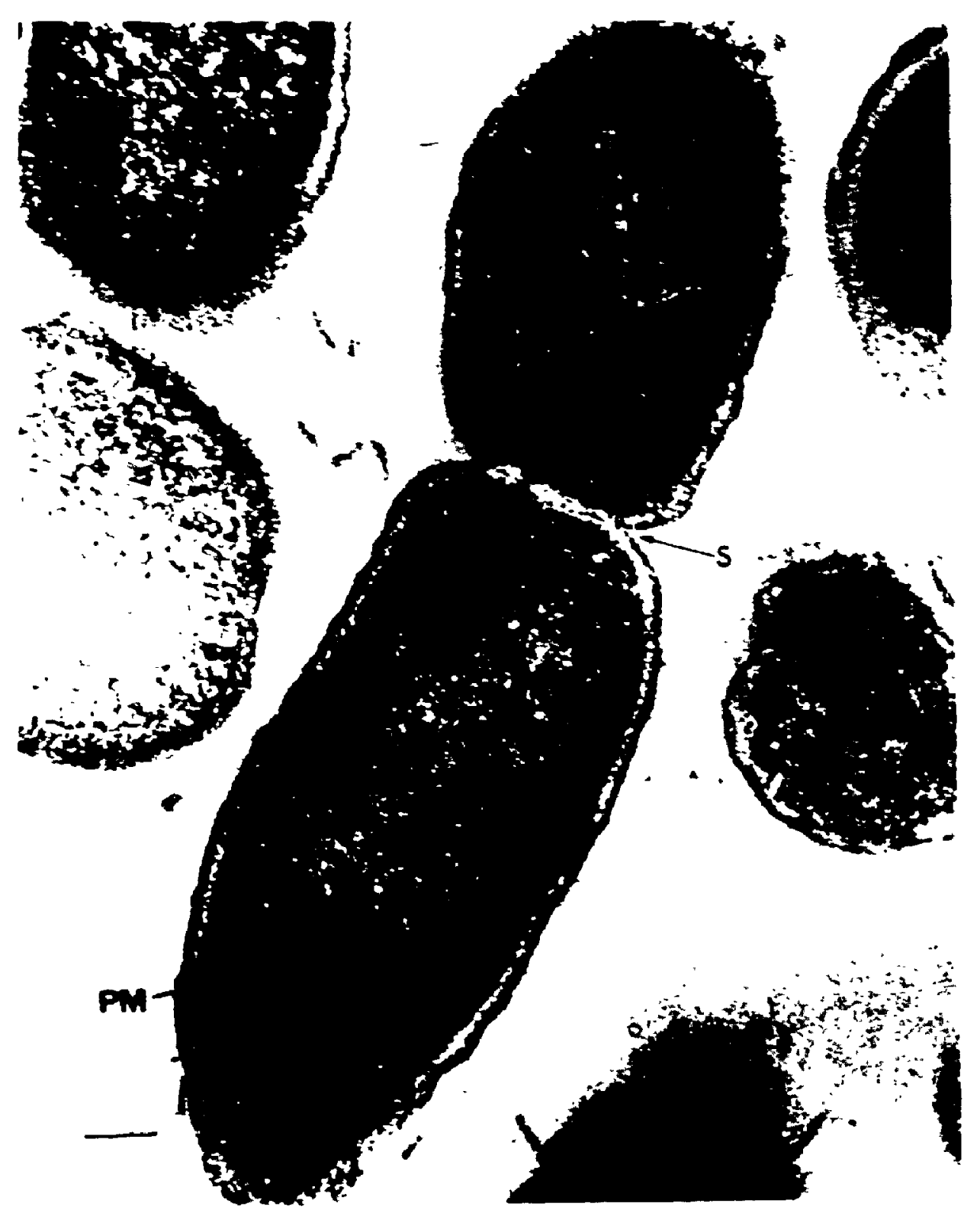




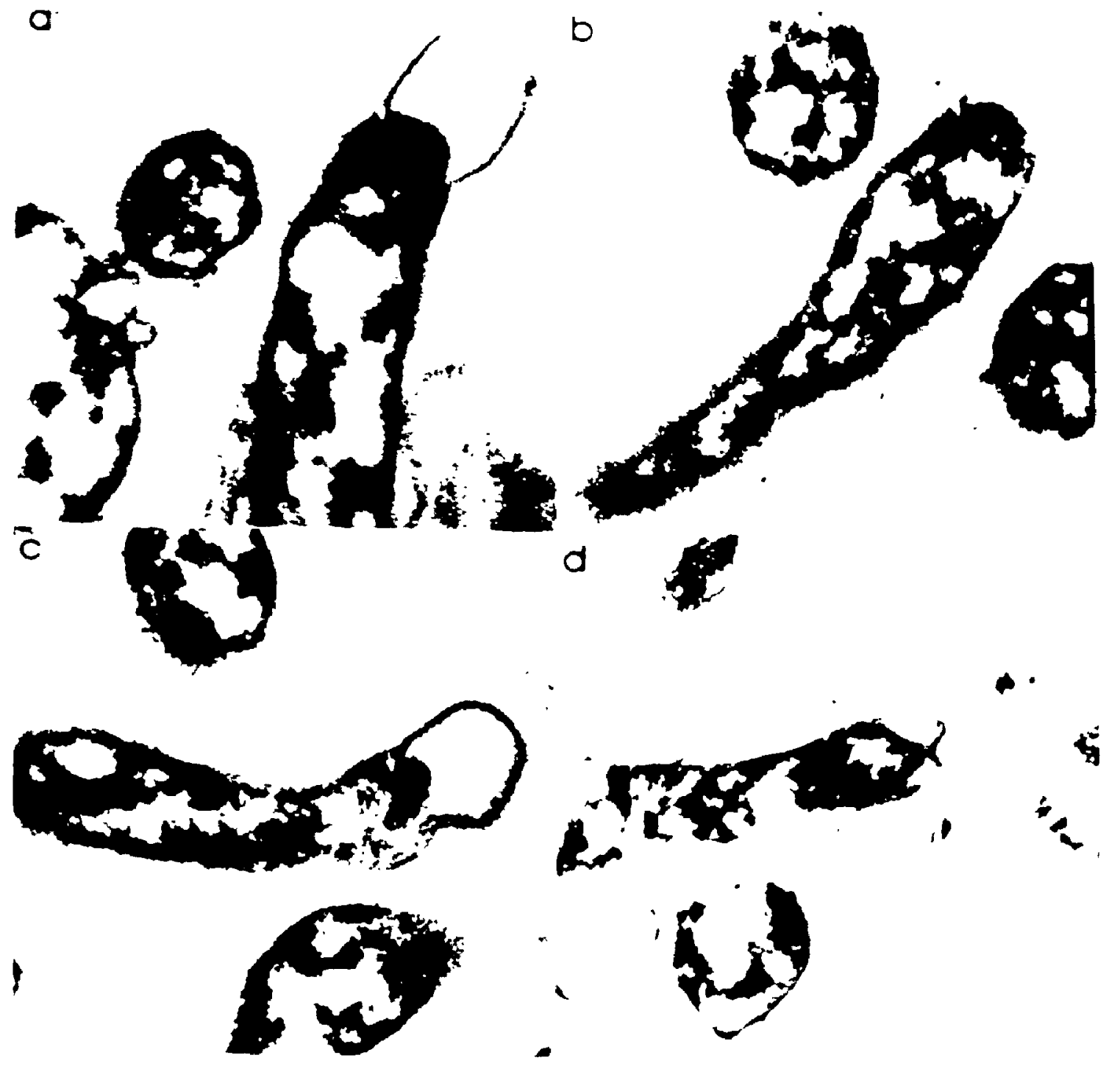



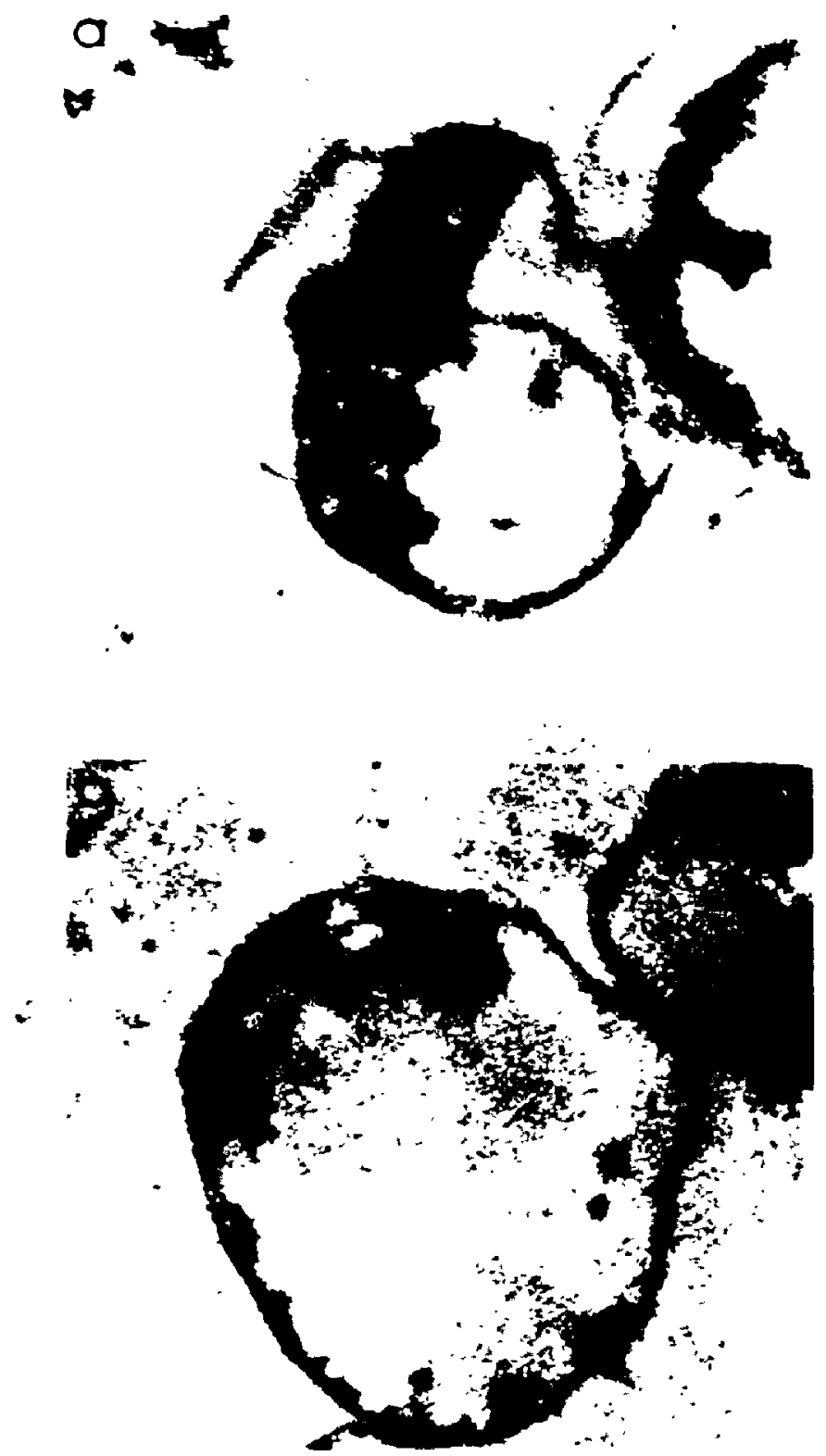


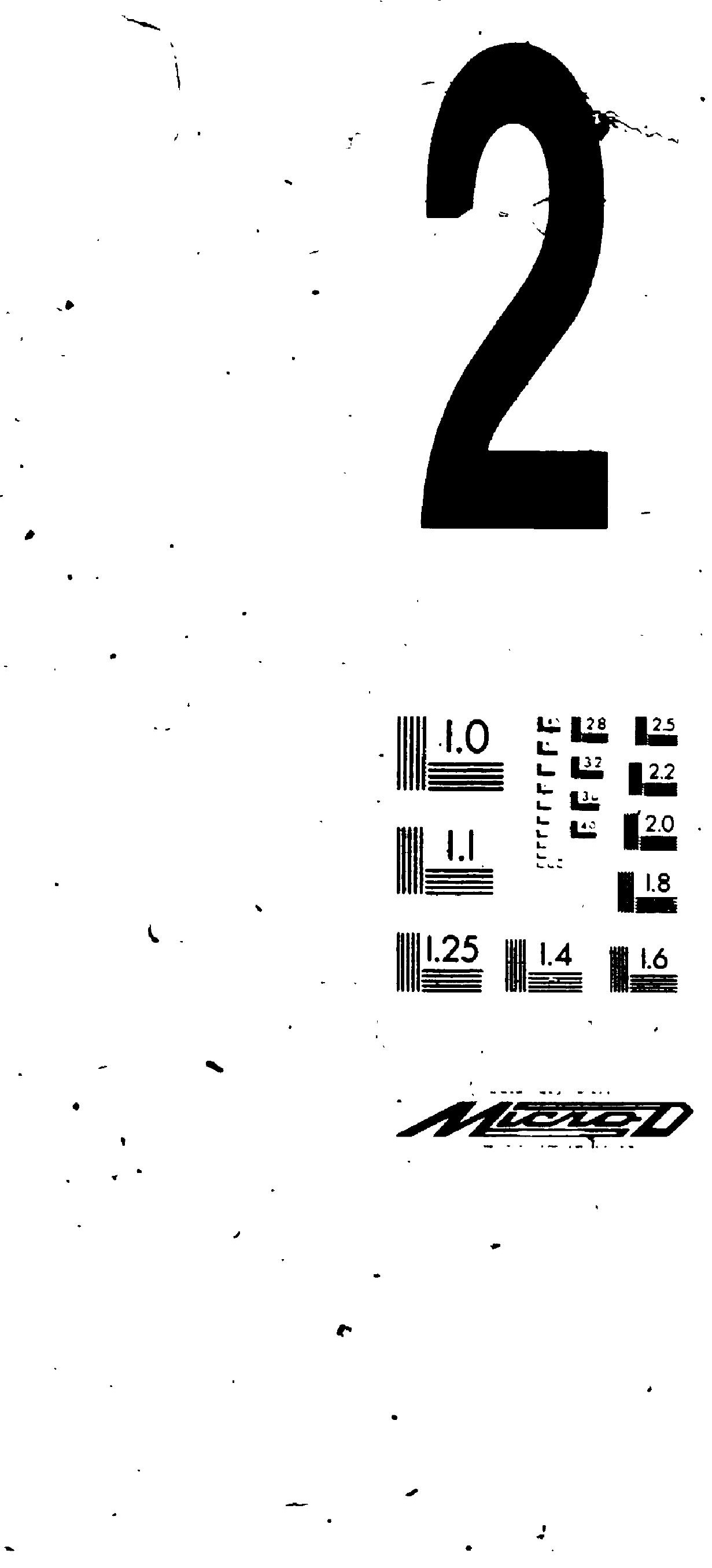


3.5. Iselation and Characterzzation of an Fl-Luke ATPase Irom i dedund

3.5.1. Anaiysis of ATP hydrelysung proteins in sheck-washel memorane supernatants

The protein in the inital shock-wash supernatant from washed membrane preparatıons was examined after precipitation with polyethylene glycol as described by . Vogel and Steinhart (1976). This protein iraçtion when analysed on a $5 \%$ non-denaturing polyacrylamiae gel contained one major protein and three to four minor protein bands (Figure 35 lanes $a$ and $e$ ). The ma.lor ' protein species. was able to degrade ATP releasing $V_{2}$ whon incubated with $5 \mathrm{mM}$ ATP plus $10 \mathrm{mM} \mathrm{MgCla}$ (Figure 35 lane c). ATP was not degraded by this protein when incubated with ATP alone (ie. no cations) or with ATP plus $10 \mathrm{mM}$ $\mathrm{CaCl}$ (Figure 35 lanes $b$ and $d$ ) This protein could not degrade GTP in the presence of either $\mathrm{Mg}^{2+}$ or $\mathrm{La}^{2}+$ ions (Figure 35 lanes $f$ and $g$ ). Two of the minior protein species hydrolysed ATP releasing $P_{2}$ with lazt ions being a potent activator and $\mathrm{Mg}^{2}$ + activating to a lesser dégree (Figure 35 lanes $c$ and- $d$ ). One of the,minor protein species degraded GTP releasing $P_{i}$ in the presence of $\mathrm{Ca}^{2}+$ ions (Figure 35 lane $\mathrm{B}$ ). 
These minor ATP hydrolysing protein species were not present in the second.shock-wash supernatant, whereas the major ATP hydrolysing protein was present in relatively large amounts. The specificity, relatively high molecular I weight (as judged by the position of the protein in a 58 non-denaturing poiyacrylamide gel, and isolation by shock wash suggested that this protein. was a candidate for an Fi-like ATPase and was therefore selected to be purified and characterized.

$3.5 .2 . \therefore$ Purification of the E1-like ATPase

The protein fraqtion isolated from the second shock-wash supernatants of cell membranes by successive cuts with decreasing molecular weights of polyethylene glycol was appliéd to a column of Sepharose 6B. One protein peak was eluted. The concentrated protein sample obtalned from the chromatography was applied to a $5 \%$ non-denaturing polyacrylamide gel and migrated as a single band (Figure 36a) demonstrating ATPase activity (Figure 36b). Table 1 shows that a four fold increase in specific activity of the enzyme was obtained after purification. The specific activity of this protein fraction. when incubated with $5 \mathrm{mM} \mathrm{ATP}$ and $10 \mathrm{mM} \mathrm{MgCl2}$, was $0.2-0.3$ units/mg of protein. 
- Table 1: Purification of Soluble ATPase

\section{Spectic Activity}

$\dot{-}$

(units activity) mg protein)

Normal Membiranesa

$0.07 \pm 0.02 d$

PEG concentrated

soluṭle ATPaseo

$0.16 \pm 0.040$

Sepharose $6 B$

Purified ATPasec

$0.30 \pm 0.030$

a. Membranes prior to enzyme extraction. 400.ug protein/ml.

b. Polyethylęne glycol 1000 (Fisher Sci.) 400 ug protein/mi.

c. Protein frow single peak eluted from sepharose $6 \mathrm{~B}$ column 400 ug protein/ml.

d. Standard error on the mpans of three experiments.
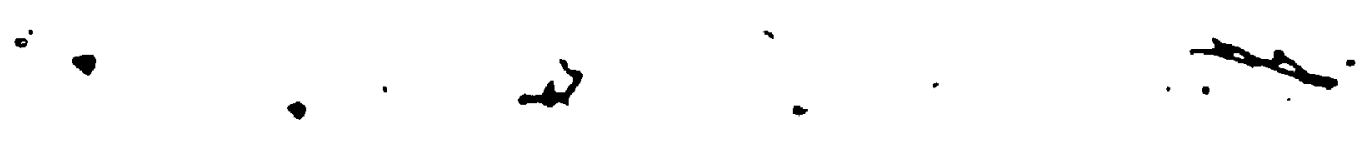


\subsubsection{Electren Micrescepy of ATPase}

Negatively stained preparations of the purified ATPase, obtained aftér colunn chromatography, revealed the presence of dough-nut shaped particles 5-6 nm in diameter (Figure.37).

3.5.4. Reconstitutien of ATPase Activity on Depleted. Membranes

ATPase activity could be reconstituted on depleted membranes by addition of $200 \mathrm{ug} / \mathrm{ml}$ of the puritied ATPase to $400 \mathrm{ug}$ of protein per $\mathrm{mi}$ of shock-washed membranes (Table 2).

$3.5 .56 \frac{\text { sibunit fomposition }}{\text { LDS and urea-PAGE rev }}$

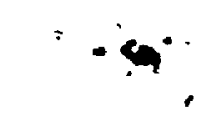
molecular weight of approximately 75,000 Daitons (Figure 38). Silver staining of the gets failed to reveal other subunits. Furthermore, the single subunit band could not , be 'resolved into 2 bands by under loading the gel or by" $\forall$. running the gel for twice the amount of time required for the dye iront to reach the botcoul of the gei. When the Fi-ATPase was extracted and partiald purified from E. coli K12 using the method of Vogel and Steinhart (1976), five subunits were obtained (data not shown).

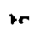


Table 2: Reconstitution of ATPase Activity in Depleted Membranes

3

Specific Activityo

- - - - - - - - - - - - - - - - - - - - - - - - - -

Normal Membranes:

$0.08 \pm 1) \cdot(.38$

Depleted Membranesd

$\cdots$

soluole ATPase

$11.3 \underline{U} \pm 13$ is

-

Reconstituted

$0.19 \pm 0.04^{t}$

Membranes

Reconstituted.

Soluble ATpase

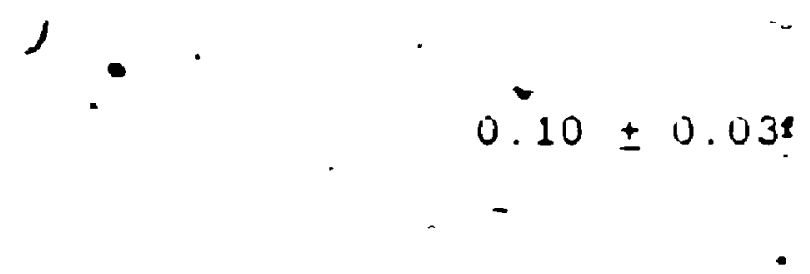

Supernatant .

a. Assay system contained 200 ug soluble ATFase -

- protein/ml and 400 ug depleted membrane pretein/ml.

b. Units of activity/mg of protein.

- c. Membranes prior to enzyme extraction. $400^{\circ}$ ú

protein/ml.

15

d. 400 ug protein /ml

e. ATPase activity was undeteçable.

i. Standard error on the mean of three experiments.

.6 
Extraction of the $\mathcal{E}$. Lejuni ATPase wath n-butanod as described by Salton and Schor (1974) also resulted in an enzyme with only one subunit, and a specific activity of 0.21 units per mg of protein.

3.5.6. Inhibitien of membrane-bound and soluble Fi-ATPase

\section{Activity}

The ATPase was examined for sensitivity to. DCCD.

oligomycin, and trypsin. The nembrane-bound. ATPase was sensitive to 5 uM DCCD, but not to oligomycin. whereas the solubie purified enzyme was not inhibited by exther chemical (Table 3). Trypsin (0.1-0.5 mg trypsinimg -protein, for 5, 10 , and, $30 \mathrm{~m} 1 \mathrm{n}$, at $37 \circ \mathrm{C}$ ) completely inhibited the actiklty of soluble Arpase (Table 4). $\therefore$

$3: 5.7 \ldots$ Enzyme activation and specificity

The purified. ATPase required $\mathrm{Mg}^{2+}$ ions $(10 \mathrm{mM})$ for activity (Figure 39), $\mathrm{Ca}^{2+}, \mathrm{Co}^{2+}, \mathrm{Fe}^{3+}, \mathrm{Zn}^{2}+, \mathrm{Mn}^{2+}$.

$\because \mathrm{Na}^{+}$, and $\mathrm{K}^{+}$did not individually activate the enzyme. As well, when $\mathrm{Ca}^{2}+$ and $\mathrm{Mg}^{2}+$ were combined at equal poncentrations (10, my) the enzyme activity was totally inhibited.

The ATPase was able to decrade ATP, reléasing: inorganic phosphate ( $P_{1}$ ), but did not degrade ADP, GTP, or 
83

Table 3: Effects of inhibitors on the membrane bound and . purified ATPage from $\underline{C}$ jejuni.

Inhibitors Conan (uM)

-

DECD

-. 1

84

5

52

Activity o ATPase

Soluble

Bound ATfase

Membrane 
rable 4: Effect of Trypsin on Soluble ATPase Activity.

Lonen

Trypsin

$1 \mathrm{mg} / \mathrm{mg}$

Time (min.)
Specific Activitya:

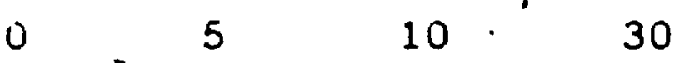

ATrase

protein)

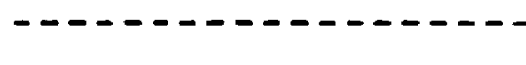

U. U

$---0 \quad 0.04$

U.09

$\dot{0} .25$

U. 1

U.

$\therefore--0 \quad--c \quad--\infty \quad--\infty$

$---b \quad---c \quad---c \quad---c$

(

a. Units of activity/mg șoluble ATPaise protein.

b. Zero time controls.

c. Activity not detectable.

\section{c. Activity not detectablo.}

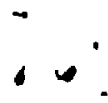


glycerol-6-phosphate (Figure 40). AMP, CTP, ITP, and TTP were also not hydrolysed by the enzyme.

The soluble enzyme lost approximately $50 x$ of its activity upon storage at $-200 \mathrm{C}$ for $24 \mathrm{~h}$, and was stable at $40 \mathrm{C}$ for one week when stored in $10 \%(v / v)$ glycerol (Table 5 ).

3.6. Immonecytochemrcal Localization of ATPase frem C jejunt

Antibodies prepared aganst the purlfied Mga

activated ATPase as described in the methods chapter ware used to localize this enzyme in whole cells using the post-embedding techique of Roth (1982). The bound antibodies were visualized by secondary labeling with protern A coated colloidal gold. The labeling pattern seen in thin sections of whole cells fixed with acrolein-glutaraldekgde (Burdett and Murray, 1974), post-fixed with osmium tetroxide, and embedded in Spurr's resin, are shown in Figures 41 and 42 . These $m$ icrographs show definite gold label at the poles of the cells, but label also appears throughout the cytoplasm. Figure $41 \mathrm{~b}$ shows the gold binding to a thin section of a minicell. Figures $41 \mathrm{c}$ and $41 \mathrm{~d}$ show localized binding of the gold to spheroplasts of $\mathrm{C}$. jejuni much like the pattern seen on. -histochemically" stained spheroplasts (Figs. $28 a$ and b). When the thin sections were etched with hydrogen peroxide. the pattern of cild label was more defined. Figure $43 \mathrm{a}$ and.b. shows the label to have bound to the polar recions of the cell, as well as throughout the cytoplasm. The .. 


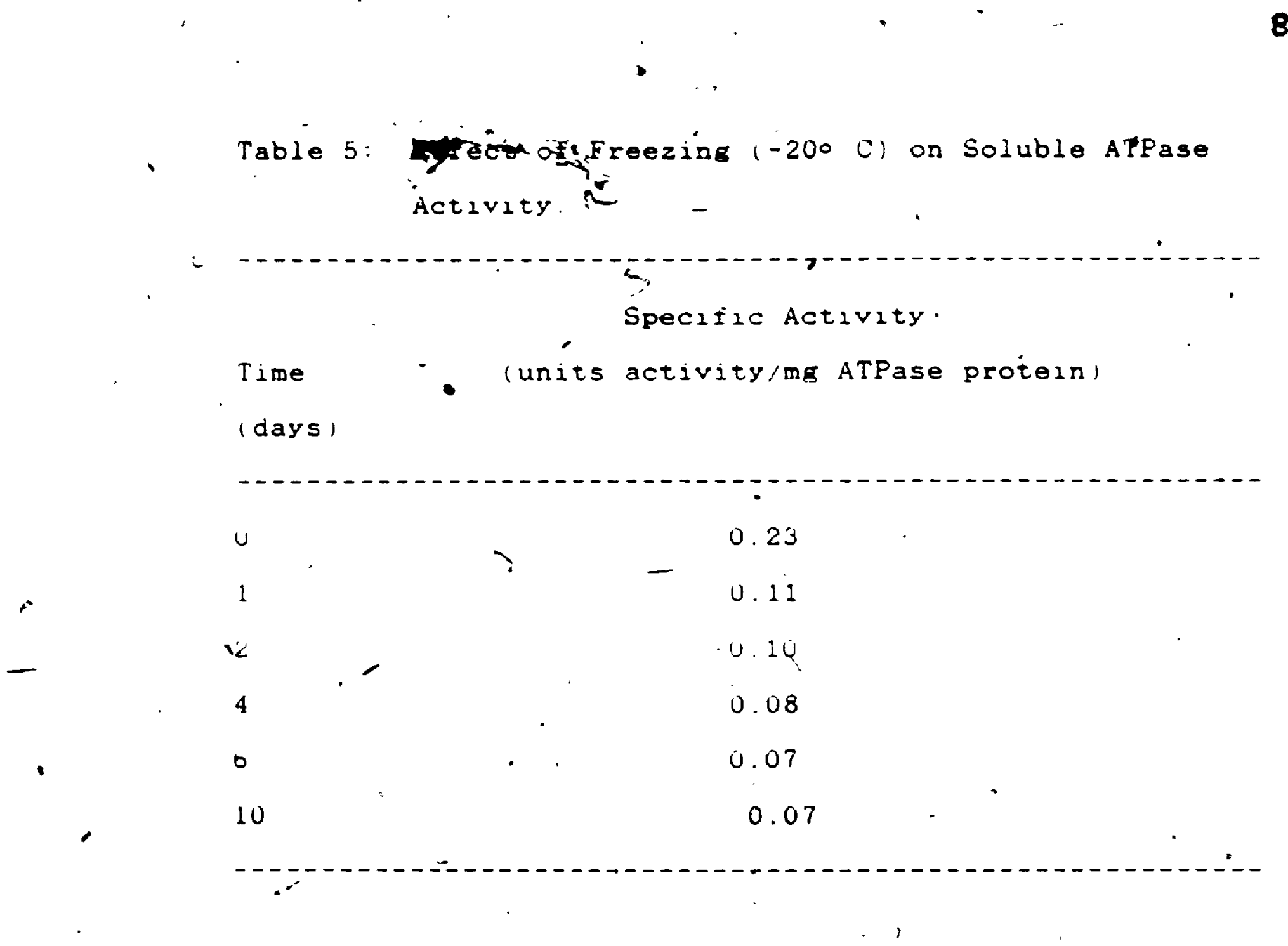

86.

Table 5: recon off Freezing $(-200 \mathrm{C})$ on Soluble APace

Activity. is

Specific Activity.

u

1

2

4

0

0.07

10

:

- $\lrcorner$

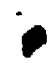

$\therefore$ 
gold label does, however, appear to have bound in zlusters in the polar regions and as isolated particles elsewhere in the cell. Cahtrol sections incubated with either preimmune IgG or no antibody ( $1 \%$ oyalbumin) showed minimal to no background labeling.

The gold labeling patterns, seen in thin sections of whole cells fixed with acrolein-gultaraldehyde (Burdett and Murray, 1974 ) and embedded in Lowlcryl KM4 are shown in Figures 44 and 45 . Figure $44 a$ and b show clustering of the gold at they pale of a ceil... as well as lsolated particles bound throughout the cytoplasm. Figure $4 b$ shows a tangental section of the polar region of a cell with a large culster of bound protein A colloidal gold particles. Isolated particles are also visible randomly distributed throughout the cell.

3.7. Antigenic Relatedness, of the ATPase from $\mathrm{L}$. jejuni to ATPases of other Bacterial Specues and Kat Liver Mitochondria (Immurebletting)

Crude antisera raised against the ATPase isolated from $\mathrm{C}$ : jejuni reacted with the purified ATPase in the Ouchterlony double diffusion assay and by crossed immunoelectrophoresis (dạta not shown). The IgG was isolated from the crude antisera and preimmune sera and the Western blotting method was used to test for 
ćross-reactivity with whole cell proteins of $d$ iejuni, $E$. soli, $\underline{V}$ cholera. S. volutans. M. voltae A. serpens MW5, and rat liver mitochondria, separated on a $12 \%$ SDS polyacrylamide gel. The IgG raised against the ATPase from $\dot{E}$. jelun reacted with four proteins from the whole cell extract of $\mathcal{C}$. jedunt (Figure 46 , Sane $\dot{I}$ ), the major reactive protein being approximately 66.000 daltons in molecular weight and the three minor proteins running below this protein in the gel. This antibody cross reacted with two proteins from the whole cells of A. serpens MW5. one corresponding to the major reactive protein in $\underline{\text { : }}$ ieduni and one of a higher molecular weight lFigure 46 , lane d). Cross reactivity was also observed with three proteins from E. celi K12 (Eigure 46, lane b). One corresponding to the high molecular weight protein seen in A. serpens MW5, one corresponding with the major reactive protein in $\underline{E}$. jeiunt, and one of a lower molecular weight (Eigure 46, lane b). This antiserum did not cross react

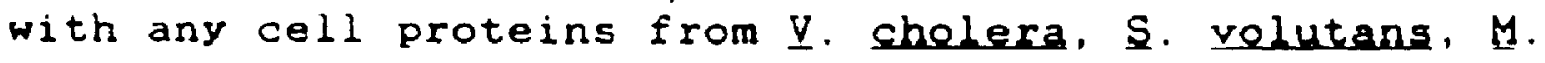
yeltae or rat liver mitochondria (Figure 46 , lanes $c$, 8. and $h)$. The preimmune IgG did not react with cell proteins from any of the organisms tested.

IgG isolated from crude antiserum raised against the F1-ATPase of E. coli K12 reacted with six proteins in the whole cells of E. cell K12 (Figure 47, lane b). This IgG 
cross-reacted with one protein species in each of tho whole cell preparations of $\underline{V}$ chelera, $\mathbf{A}$ serpens MW5.'. s. velutans, and rat ijver mitochondria (Eigure 47, lanes $c, d, e$, and $h$ ), but did not cross react with any whole cell proteins from either $\underline{C}$ lejunl or M. veltag IEigure 47. Lanes $I$ and $g$ ). 


\section{. 2 Ehapter 4}

$\cdot$

Discusszon

The existence of poiar membrane as a structure has been known tor the past twenty four years. However. previous studies. Ot this interesting structural complex. associated with cytoplasmic membrane have $11 \mathrm{~m} 1 \mathrm{ted}$ themseives to trying to deine its ultrastructure and compling liets of organisms possessing it. The ine - ultrastructure at the macromolecular level, biochemical composition and function(s) of polar membrane have not been investigated to date. Its location at the poles of the cell surrounding the flagellar insegtion point has led to the hypothesis that polar membrane functions in energy transductions (Murray and Birch-Andersen, 1963). it has also been suggested that this structure serves as an anchor to which the flagelila are attached in organisms possessing a polar tuit of flagella (Cohen-Bazire. 1967; kemsen, et al.,1968), but little else is known about it even though it is found in a variety of lophotrichous Gram negative bacteria.

This study was undertaken to clarify the nature and suggest the function of polar membrane in $C$. jeiund. This 


\begin{abstract}
$?$
bacterium was chosen ior this work for the following reasons: it possessed polar membrane. It had a single polar tlagelium, its poles were slightly tapered allowing. for high resolution on thin section, and it was found to produce minicells from its polar regions with cytoplasmic memorane enriched in the polar membrane structure

Recognition that the component units of polar memorane. the stalks ana knobs. were structurally similar to the ATPase of the inner mitochondrial membrane and the cytopiasmic memorane of varlous bacterial specios ikacker. 1967; Harcid. i972) led to a study of the ATPase activity of this organism and its relation to the polar membrane structure.
\end{abstract}

\title{
4.1." Ultrastructure of Relar Membrane
}

- The basic structare of polar métorane in 4. jejunz

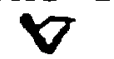

was previously described by Ritchie et al. (1966). The. results obtained trom thin sections of whole cells in this study were in agreement with the former work. Comparison of the structure seen on longitudinal thin sections and cross-sections through the polar region suggested that polar membrane lined the inner surface of the cytoplasmic membrane at the poles of the cell in the form of a cylindrical cap. The cytoplasm contained within this area was found to contain fewer ribosomes than the rest af the 
cytoplasm: an observation previously noted in A serpens ay Murray and Birch-Andersen (1903). The spherical inciusion body seen within this region. which was denseiy stalned with lead citrate, may represent a phosphate storage granuie and may be related to the function of polar membrane.

visualization of polar memorane on the cytopiasmic membrane close to the site of septum iormation, al though not a consistent result. suggests it is laid down prior to daughter.cell separation and may polnt to its requirement in the normal tunction of a young cell.

The association of polar membrane with the Ilagellar basal complex was further defined and found to encroach on the lateral margin of the basal complex to varying degrees trom cell to cell. This structure was never seen to cover the area in the basal complex where the $M$ ring was located indicating there was no visible contact or linkage with this organelle, despite the earlier speculations that there might be such a linkage. It should also be noted that polar membrane was sometimes observed at random sites along the cytoplasmic membrane in $\mathrm{C}$. jejunj and not assoclated with the flagellar insertion site.

The component units of polar membrane in $\underline{C}$. jeiuni were found to be smaller in dimensions-than those seen in A. serpens MW1 1 and those described for polar membrane in 
E. mebulis (Remsen, et al., 1968). The stalks were $2-3 \mathrm{~nm}$ in diameter, $5 \mathrm{~nm}$ in length and the knobs were $5-0 \mathrm{~nm}$ in diameter in, $\mathcal{G}$. Lesunt, whereas, in these other organisms the stalks were $3-4 \mathrm{~nm}$ in diameter, $5 \mathrm{~nm}$ in length and the knobs were 8-9 n!m in diameter. This observation may account for the difirculty in resolving the components of this structure on thin sections of $\mathrm{C}$ lejun and suggests that although polar membirane is found in many iram negative bacteria, suggesting a similar iunction, the size or form of component macromolecules may vary across the genera.

The impression that the cytoplasmic membrane in the region of the polar membrane is of a móre rigid charactor than the rest of the lateral membrane, as seen both on thin sections of whole cells and in fractionated cell envelope preparations. sugeests this portion of membrane is different from the rest of the lateral cytoplasmic membrane and may simply be a result of an increased protein to lipid ratio reflecting the insertion site or the polar membrane stalks.

The observation of arrays of dough-nut shaped particles on membrane fragments near the lagellar insertion point and in intact polar vesicles'suggested that these structures were components of the polar 
membrane complex, because they corresponded in size $15-0$ nm, Iorm, and location to the innermost part of the structure seen in thin sections. These complex particles appeared to be arranged in an hexagonal array on the inner suriace of the cytoplasmic membrane. Ritchie, et al.. (1968) suggested that the polar membrane structure was arranged in a honey comb lattace and these results support this hypothesis

The tine $(3 \mathrm{~nm}$ repeat) hexagonal array seen on ilpid depleted membrane sineets may represent the insertion sites in the cytoplasmic membrane of the stalk portion of the polar membrape. Thisfestucture had almost a crystaline appearance and was sipilar to the two yimensional crystals of ÁTPase seen. in saccoplasmic fétictium membrane after Indusition with vanadgte orjinorgaric phosphate (Skriver. et al., 1981; Maunsbach, et al.,"1982; Herbert, at al." 1982: Dux and Martonosi, 1983a and b). This suggested that polar membrane might be a naturaliy occurring two dimensional momorane crystal and this formation might result in an incrose or decrease in its. functional activity. The ATPase activity is inhibited in the artifically induced sarcoplasmic membrane crystals. (Herbert, et al.. 1982). This could be due to-inactivation by the vanadate and the $\mathrm{Pi}$ or a conformatifinel, change in the active sites of the enzyme in the crstalifine array. 
Alternatively. the ciose proximity of the globular head units (knobs) could result in fein-protein interactions which allow for positive cooperativity in ATF hydrolysis thereby alfowing for an increase in energy production. (Munoz, 1982).

The apparent lability of the polar membrane structure when isolation was attempted and the incressad frequency of obseryation of these structures when membrane - preparations included a reducing,agent, suggested that. polar membrane may be sensitive. to oxyzen. This conclusion is plausable consideringlthe ist that $\mathcal{C}$ iejunj is a microaerophile.

4.2. Minicell tormation by ci jejuni.

The observation of small tiagellated structures in late $10 \mathrm{~g}$ and stationary phase cultures as well as whole cell prepartions of $\mathcal{C}$. Lefuni led to a study of their nature and formation because they might, have provided an enrichment of the polar membrane. It was found that these structures were hinicelis produced from the poles of the cell through a process involving constriction of the plasma nómbrane and segration of the polar regions af the celds including the polar membrane structure. "The protils $\because \quad \ldots$ of the peptidoglycan layer in the cell wall, experted tis lie between the outer membrane and the cytoplasmis 
membrane. was not often seen on thin section of young

- .cells and could not be located on thin sections of the sègregating terminal regions of the minicells. This may be due to the collapse of the periplasmic peptidoglycan ...

gel against the outer membrane during dehydration as. described by Hobot et al. (1984). It is assumed that the integrity of the peptidoglycan must be disturbed in the. region of minicell formation, but remains intact atong the main length of the cell because the rods did not spheroplast.

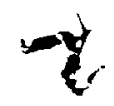

The experience of this laboratory with portions of cytoplasmic membrane bearing polàr membrane has been that it becomes sharply curved with the conoave side on the inside. This suggested that the turgor change likely in these colls during the initial event of minicell formation would allow this curvature and make a central contact and qnnealing of membranes the more likely. The prompt closure of the cell portions would then provide a cel1-11ke environment and obviate the dissolution of the polar membrane structure that was usually experienoed when attempts were made to fractionate it. The survival of the rod portions of the cells were not studied. but must be. assumed to be more problematical.

The terminal everits in the formation of these structures here not observed, but must be assumed to. 
involve a breakage of the outer membrane component of the cell wall allowing the release of these segregated polar regions, followed by fusion of the ruptured outer membrane. The formation of these minicells did not appear to ofcur by normal septation or constriction, (Burdett and Murray, 1974: Adler et al., 1967). It interesting to note that another polar flagellate, A serpens, produces similar structures (Terasaki, 1970). This discard of the flagellated poles the ceil might be a survival feature used to rid the cell, of its energy-requiring rlagellar dpparatus or it could be merely another degenerative feature related to coccoid body formation as described by Og8 (1962).

As stated earlier, one of the reasons for studying polar membrane in $\mathcal{C}$. jejuni was the observation that this organism pinched off its poles producing minifells complete with cytoplasmic membrane and polar membrane.

Attempts were made to use this phenomemon as a means to . gain a membrane fraction enrichod in polar membrane. This result was defeated by the sticky properties of bóth cells and minicells, which prevented a clean isolation of this mombrane fraction. 
4.3. Lecalization of ATPase Activity in whole cells by Histochemical staining
Tie localization of heavy internal lead deposits at the poles of the celis, after histachemical staining for ATPase activity, suggested that polar membrane is an assembly of ATPase rooted in an area of membrane. The presence of lighter lead deposits elsewhere in the cell may suggest the presence of other ATPases or simply the ' presence of the polar ATPase randomly distributed along the cytoplasmic mmbrane. Voelz (1964) showed, by histochemical staining (using the modified Wachstein-Meisef method of Otero-Vilardebo et al., 1963), the ATPase of $\mathbf{E}$. celi to be randomly distributeri on the internal surface of the cytoplasmic membrare, a result contirmed by this work. Vaituzis (1973) observed that. Spirillum serpens (ATCC 11330), when histochemically stained in thi: presence of ATP and $\mathrm{Mg}^{2+}$, did not reveal any activity preferentially associated with the poles of . the cell. This organism appeared to have ATPase adtivity concentrated in the periplasmic space around the whole. coll: The present study has shown that $A$. serpens MW5 shows random deposits of lead throughout the cytoplasm when incubated with ATP and $\mathrm{Mg}^{2}+$ and heavy lead deposition 1 in the polar. reglons when incubated with ATP and $\mathrm{Ca}^{2+}$. This result suggests that the polar ATPase of this 
organism is activated by $\mathrm{Ca}^{2}+$ and not $\mathrm{Mg}^{2}+$ as in $\mathcal{L}$ jejuni indicating that the function of polar membrane as an ATPase may cross generic boundaries but the biochemical properties of this structure may differ irom organism to

- organism. Deposits in the periplasmic space were not observed. The discrekancy in the ATP-Mg ${ }^{2}$ results may be due to the strain difference or to the prefixation with glutaraldehyde. Vaituzis $(1973)$ used $6.5 \%$ glutaraldehyde prior to histochemical staining and this may have resulted in inactivation of internai ATPases in this organism.

Vaituzis ( 1573 ) also described the presence of lead deposition. in the polar regions of vibrie metchnikoviz when incubated wi.th ATP-Mg2t: This organism, Like other vibrio sp. 'may possess polar membrane and as with $\dot{\text { s. }}$. jejuni this result may suggest a relationship between this structure and ATPase activity.

It has also been shown that the ATPase of Mycoplasma Rallisepticumi is localized at the poles of the cell (Munkres and Wachtel, -1967), however, polar membrane is not visible in thin sections of this organism.

The histochemical stainine results found in $B$. cereus are simllar to those found in B. Lichenitermis by Vaituzis (1973.), sugéesting a sandom distribution of ATPase activity within the cell. Polar mémbrane has not been described in thís genus, but studies have been done 
On the natizs and location of its ATPase (Abram, 1965;

- Mirsky and Baricw, 19711

M. luteus (formally M. lysodeikticus), a (iram

positive coccus, appears to have either two different ATfases or one with different activities depending on its activation by $\mathrm{Mg}^{2}$ - or $\mathrm{Ca}^{2+}$. ATPase activity' was more localized when $\mathrm{Mg}^{2}+$ was used and randomly distributed when $\mathrm{Ca} a+$ was the

- activator The Gram negative coccus (but yet Gram positive in reaction) $D$. radiodurans showed the opposite results to M. Luteus. Again, polar membrane has not seen described in either of these genera, although a great deal of work has been focused on the ATPase of M. lysodeikticus (Chung and Salton, 1980, Ellar, et al., 1971; Huberman and Salton, 1979; Mollinedo, et al., 1983; Mollinedo, et asl., 1980; Munoz, et a... 1968; Munoz, et al.. 1989; Oppenheim and Salton, 1973: Salton, et al.. 1968; Salton and Schor, 1972; Salton, et a.t. 1972; Urban and Salton, 1983a and b). This ATPase was found to be activated primarily by $\mathrm{Ca}^{2}+$ and to a lesser extent by $\mathrm{Mg}^{2}$ and was found to be randomily distributed on the inner surface of the cytoplasmic membrarie. It appears. therefore, that histochemical staining of $M$. Luteus showed the presence of this ATPase and its differential activation by $\mathrm{Mg}^{2}+$ and $\mathrm{Ca}^{2+}$. 
4.4. Isolation and characterization of an $F_{1}$ - like atpase from E jejunt.

The results obtained from analysis of the initial shock-wash supernatants of $\mathcal{Q}$. jejug membranes for ATPase activity revealed the presence of three protein species (one major species and two minor ones) capable of degrading ATP and releasing $P i$. The major protein species was chosen for study in that it specificaily degraded ATP and was activated oniy by $\mathrm{Mg}^{2}+$ cations similar to the ATPase activity seen in histochemically stained iells The other active protein species appeared to be general phosphatases in that they degraded a variety of nucleotide triphosphates and glycerol-6-phosphate. They, were also primarily activated by $\mathrm{Ca}^{2}+$ thereby suggesting no relationship to the ATPase activity seen at the poles of the cell.

The major protein species possessing ATPase activity was purified by the method of Vogel and Sternhart (1976) and appeared to be homogenous as judged by polyacrylamide gel electrophoresis, even though the enzyme purification was only 4 fold. This relatively low purification factor may have resulted from the use of a purification method designed for extraction of the enzyme from E. celi. although, extraction with n-butanol, as done with the enzyme from M. Lysodejkticus (Salton and Schor. 1974). 
gave the same results. It has been noted that a great deal of variation exists in the procedures for ATPase release and purification from mitochondria. chloroplasts and bacterial membranes and a method that is successiul. for one organism may not work in another (Ishikawa, and Lehninger, 1962: Munoz, et al., 1968 and 1969: Knowles and Penefsky, $\ddot{1972}$ : Mclarty and Racker. 1966; Strotmann, et all. 1973; Abrams, 1965; Davies and Bragg, 1972; Hanson and Kennedy, 1973; Futal, et as., 1974; Nełson, et as.. 1974; Mrrsky and Bariow, 1971; Ishida and Mizushıma. 1969: Hachimor1, et al., 1970: Adolfsen and Moudrianakis, $1971 ;:$ Higashi, et al., 1975; Riebeling and Jungermann. 1976 ; Yoshida et al. 1975;. Reed and Raveed, 1972; Johansson, et al. , 1973 , It istgenerally assumed that solubilization of Ey-ATPaged requiteo the removal of divalabtcationo. as these enzymes are associated with the membrane by a combination of ionic forces and hydrophobic, interactions. The relative importance of these forces and the degree to which they act may explain the differences seen in solubilization regimes. In the case of the enzyme in $\underline{C}$. jejunt, equal purification was obtained whether EDTA or an organic solvent was used, which suggested that some other factor or factors were involved in the low purification factor obtained. It is possible, considering the microaerophilic nature of $\mathrm{C}$ : jeiuniand the fact that a 
reducing agent added stability to the complex, that the. ATPase was oxygen sensitive and this could account for the low purification fiactor and specific activity observed, as no precautions were taken to remove oxygen from the extraction and purification butiers. The possibilty also exists that due to the crystabizne nature of polar membrane and possibly this ATPase, the isolated enzyme may be rendered partially inactive after removal from its. closely packed conditions on the memorane ór it may be partially inactive and awalting some inal activation step. However, it should be noted that. despite the solubilization procedures used, there also exists a groat deal of variation in the level of. ATP hydrolytic activity (i.e. specific activity) of purified $F_{1}$-ATPases from different sources. the specific activity of the enzyme isolated from $M$. Lysodelkticus is very low 16-8. umol/min/mg of puotein) even though this enzyme exhibits latency (Ishikawa and Lenhninger.. 1962: Munoz, et ax... 1968: Munoz, et al., 1969). The specific activities of: the bacterial $F_{1}$-ATPases also differ in that the enzymes from anaerobes and facultative anaerobes possess mid-range activities in the hydrolysis of ATP, those from aerobes. (particularily those of Bacillus spp.) have vory high specific activities (500-1000 umol/min/mg of protein), and 
those ifom the strict aerobes (M. Iysodeikticus, A.

taecalis, $M$ phlez, have very low specific activities is-8 umol/min/mg of protein) (Abrams and Smith, 1974; Abrams. et as.,1976; Futa1, et al., 1974; Nelsori, et al., 1974:

Serrahina-zieger and Monte11. 1978: Monteil and

Serrahina-żęger. 1978. Munoz, et al., 1969. Adolfsen and Moudrianakis. 1976: Ritz-Gold and Brodie. 1979;

Ritz-loid, et as. 1979; Bog1n, et as, , 1970; Ritz and Brodze, 1977,

Al bacteriai $F_{1}$-ATPases share the property oI appearing as spherical structures on the membrane and in puritied form (Munoz. 1982). The stalk portion or the enzyme is not frequently observed (Munoz, 1982). The purified ATPase from $\breve{C}$. Leiuni also possesses this characteristic, although its dimensions (5-6 nm) are" slighty smaller thàn the $9 \mathrm{~nm}$ described for many other

- bacterial $F_{1}$-ATPases.

The ATPase of $c$. jeiuni could be reconstituted on enzyme depleted membranes restoring ATP hydrolytic activity. This result súggested that the:enzyme was not alped or damaged during the isolation and purification procedures used. It does not, however, ensure that the entire $F_{1}$ portion 'of' the eneyme was removed from the : membranes and is is possible that parts of the Fi structure leg. Other sabunits, were stili associated with 
the membrane after extraction.

Thelpurified active part of the ATPase of $\mathcal{G}$. Lejunt appeared to be composed of one subunit. Which is a situation observed in Lactobacldius casel (Biketov, et as., 1982; Tikhonova, et al., 1983). Uther subunits might be lost during isolation and purification or may be lost due to oxyger lability. It is aiso possible as stated earlier that not all of the slibunits were extracted trom the membrane, but the methads were effective at extracting muitiple subunits from E celi K12.

It has been generaliy assumed that $F_{1}$-ATPases are composed of five subunit types (Munoz, 1982), although some variablity has been observed. The delta subunit of E. celi Fl-ATPase disappears during. certain purification procedures (Bragg, et al., 1973; Azocar and Munoz, 1977). The subunit composition of the $F_{1}$-ATPase of $M$. lysodeidicus shows great variation depending on the purification method, analytical techniques used, enzyme stability and the use of different substrains (Munoz, et al., 1969; Mollinedo, et al., 1980; Andreu, et al.. 1973: Risi, et al., 1977; Carreira, et al., 1976 and 1977; Andreu and Munoz, 1975). In Strep. frecalis F1-ATpase three subunits were seen using urea gel electrophoresis: and four subunits were noted using SDS-pel electrophoresis (Schnebli, et 1., 1970), a fifth subunit was located when 
the enzyme was purified in the presence of $\mathrm{Mg}^{3}$ ( Abrams. et al. 1976). A similar situatzon was found in the . analysis of $\forall$ lysodelsticus Fl-ATPase, the subunit composition was less complex under urea gel analysis than SDS-gel eiectrophores $15^{\circ}$ and variations in the stainang of this protein with urea were observed (Schnebli, et al. 1970) The F:-ATPasfes from $B$ megaterdum and $B$. subthis have a simpler subunit composition, only the two major subunits (alpha and beta) have been consistently lsolated (Mirsky and Barlow, 1971; ishrda and Mizushıma. 1969: Monteil and Serrahima-Zieger, 1978), and as mentioned. earlier the $F_{1}$-ATPase isolated from lactebachlus casei possesses only one subunit (Biketov, et al. 1982 ; Tikhonova, et al. (1983).

Therefore, considering the variation which exists in the subunit composition of a variety of bacterial $F_{1}$-ATPases it is plausible that the $F_{1}$-ATPase isolated from $\mathcal{C}$. dejuni possesses a single subunit type, although further work in this area is needed to state this conclusively.

The effects of the inhibitors DCCD and oligomycin are in agreement with those foind for other procaryotic F1-ATPases (Haddock and Jones, 1977; Harold, 1972) and further suggested this enzyme belonged in the procaryotic H+ATPase class. The inability of trypsin to activate this 
enzyme suggested that it was not in a latent form as was the case for the enzyme from $M$. Iysodeikticus I Ishikawa and Lehninger, 1962; Munoz, et as., 1968, and 1969,

The enzyme isolated from $\breve{c}$. jejunz was specifically activated by $\mathrm{Mg}^{2}+$ cations. a characteristic also pointing. to zts classification as a $F_{1}$-ATPase, however, its inhibition by $\mathrm{Ca}^{2}$ - is unusual in that most $\mathrm{Mg}^{2}+$ dependent ATPases can be activated in a minor way by Caz+ Downze. et al. $: 1979)$. The activation of F:-ATPases by dations is a another property which shows ciear differences depending on the origin of the enzyme. Fl-ATPases of animal origin i.e. from mitochondria) require $\mathrm{Mg}^{2}+$ as an activator for the degradation of ATP giving specific activities of 100 umol ATP hydrolysed/min/mg of protein (Penetisky, 1974 and 1979; Pedersen, 1975; Pedersen, et al., 1978). The Fl-Arpases of chloroplasts are activated by $\mathrm{Ca}^{2+}$, however their specific activities are very low unless activated by heat treatment, trypsin digestion or dithiothreitol (Nelson, 1976; McCarty, 1979; Baird and Hammes, 1979; Vambutas and Racker, 1965; Matsubara, et al., 19811 . Alternately, bacterial $F_{1}$-ATPases show a more complex pattern of activators and specific activities. Generally the activatiors of the soluble enzymes are $\mathrm{Mg}^{2}+$ and $\mathrm{Ca}^{2}+$. although other metal cations have been found. to be activators. and it appears that enzymes from anaerobes and 
facultative anaerobes are $\mathrm{Mg}^{2+-d e p e n d e n t ~ A T P a s e s}$ while. those torm aerobes are Caz+-dependent ATPases (Munoz. 1982). However, these enzymes all appear to behave as Mgí ATPases when bound to membranes (Munoz. 1982). The observations reported here on the enzyme from $\underline{V}$. jejuni show clear differences to other $F_{1}$-ATPases and these may stem from the microaerophilic dature of this organism.

The $F_{1}$-ATPase from $\mathcal{C}$. dejun specifically degraded ATP, but at a very low rate. There maght be hydrolytic activity against other suostrates but such an activity was not detectable by the methods used in this study. It is known that bacterial Fl-ATPases generally possess hydrolytic activity for nucleotide substrates other than . ATP. usually with lower specific activities (Mirsky and Barlow, 1971: Davies and Bragg, 1972;. Hanson and Kennedy, 1973; Abrams and Smith, 1974j.

The ATPase from $\mathcal{f}$. jeiuni also exhibited cold inactivation, a property. common to Fl-ATPases from mitochondia. cholroplasts and other bacteria (Peneisky and Warner. 1965; Bennum and Racker, 1969; Livne and Racker. 1969. Monteil ar Serrahima-Zieger..1978). The Fl - ATPase of B. meraterium is very cold labile (Mirsky and Barlow, 1972) and the cold sensitivity of E. coli ATPase depends on the conditions of enzyme extraction and on the strain (Azocar and Munoz, 1977; Hanson and-Kennedy, 1973; Davies and Brage, 1972; Futai, et. al., 1974). 


\subsection{Immunecytechemical iecalization ef ATPase in C.} seiuns

The immunocytochemical localization of this. ATPase by immunoelectron microscopy suggested that it was? associated with the polar membrane structure because the colloldal gold label was clustered at the poles of the . cell. The location of the enzyme lusing colloidal gold-antibody detect fin methods) elsewhere in the coll suggested the presence of the ATPase generaliy distributed at isites other than the poie. It should be noted that often the polar membrane structure was visible on thin. sections but the gold label was not seen bound to the structure. This would be expected due to the intirent problems experienced in the post-embedding labeling. technique because of the orientation in the resin embedding. When the structure is visible it is cut across. by the plane of the section ( $i$.e. in the resin) and fow if any of the target molecules are avallable as an antibody binding site (Roth, 1982). One would hope for a tangential section to the polar membrane with revelation of a number of antibody binding sites. -

Me use of Spurr's resin for this technique and osmium: fixation of the cells gave acceptable results. Howewer, etching of the sections increased the gold labeling and enhanced the localization of the enzyme. This 
is an indication that the enzyme's antigenicity was not greatly affected by the $F$ ixation and embedding procedures. The use of Lowicryl RM4 for embedding $C$. jejuni provided a better method for antigen preservation because samples were not subjected to high temperatures for polymerization of the resin. It was found that larger clusters of gold particles at the poles o $\overline{\bar{I}}$, the cells were seen on Lowicryl KM4 sections and again the best result was seen in sections tangential to the polar regions. However, the cell wail and memorane contrast was very poor and potar membraine could not be seen.

The gold labelling pattexn was consistent with the lead deposition pattern seen in histochemically stained cells. These results and the structural similarities suggest that polar membrane and the purified $\mathrm{Mg}^{2}+$-dependent ATPase from $\mathrm{C}$. jejuni are directly related. The location and concentration of this ATPase at the poles of the cells, near the flagellar insertion point, suggests it may function in energy transduction or proton transiocation for flagellar rotation. The proctuction of . minicells may indeed be a mechanism useful to the cell for ridding itself of this concentrated ATP hydrolysing region. 
4.6. Antigende relatedness of the ATPage from $i$ jejuni to ATPases of other bacterial species and rat liver mitochondria

The antibody prepared against the ATPase from $\dot{.}$. jejuni recögnized four protein species in whole cell extracts of this organism. This result may suggest the presence of other subunits of this ATPase which were not extractable using the methods of Vogel and Steinhart (1976) or of Salton and Schor (1974) but, more Iikely, may,' simpiy be cross reaction with other cell proteins sharing some specificity.

The cross reftivity of this antibody. with protein species from whole cell extracts of E. celi K12 and A. serpens MW5 suggested some conservation of sequences in these proteins, but the relationship to ATPase is uncertain. There are broader differences because $A$. serpens MW5 also possesses polar membrane, has an enzyme that appears to activated by $\mathrm{Ca}^{2+}$ and inhibited by $\mathrm{Mg}^{2+}$. The other three bacterial species.tested also possess polar membrano, but the antibody to the $\underline{\dot{c}}$. jejuni ATPase did not cross react with any cell proteins in these organism, nor did it cross react with mitochondrial proteins. These results suggest that the composition of polar membrane may differ depending on its oriein. although its function may be similar, and this ATPasé may 
have evolved along different lines than those for other bacterial. species and mitochondria.

The antibody prepared against the $F_{1}$-ATPase of $E$. celi K12 showed cross reactivity with $A$. serpens MW5, V. chelera, $\dot{s}$ velutans and rat liver mitochondria. It did not cross react with any cell proteins from elther $\underline{\underline{0}}$. jejuni or Methanococcus. voltae. As well, a monocional antibody to the beta subunit of E. coli K12 did not cross react with í. dejung (S. Dunn. Dept. Biochem., Univ. Western Unt., personal communication,. It has been shown ohat monoclonal antibodies prepared against the beta subunit of the E. seli ATPase show cross reactivity with a variety of bacterial genera, and beta subunits of."

mitochondrial and chloroplast Fl ATPases (Dunn, 198̈5): This suggests that this subunit has been highly conserved throughout evolution. However, it appears that the ATPases of $\mathcal{C}$. jejuni and the phylogenetically separate archaebacterilim $M$. voltae (Woese, 1987) may have evolved along different pathways. The cross reactivity of the $\underline{C}$. jejuni antibojy.with E. seli K12 may represent a domain recognized in an otherwise unique protein.

\subsection{Cenclusions}

- This study examined the ultrastructure and nature of polar membrane in $\mathcal{C}^{\circ}$. jejuni and showed that the structure 
was composed of dough-nut shaped particles $15-6 \mathrm{~nm}$ in dlameter) arranged on short stalks in an hexagonal array on the membrane. The cytaplasmic urembrane, when depleted of its lipids, possesséd arếs with a fine hexagonal array ( $3 \mathrm{~nm}$ repeat) and this may repnesent the staiks themselves or the insertion sites of the stalks of the polar membrane structure into the membrane, Polar membrane was found to be a tightly packed array suggesting it to be a naturally occurring two dimensional crystal similar to the vanadium induced ATPase irystals seen on sarcoplasmic membranes (Dux and Martonosi, 1983a).

$$
\text { It was also found that visualization of this }
$$

structure on the membrane was enhanced under conditions of high tonic strength and in the presence of a reducing agent, suggesting that polar membrane was sensitive to oxidation. This result emphasized the need for increased study into the oxygen sensitivity of proteins isolated from $\mathrm{C}$. jejuni.

This study also described the presence and formation of minicells, possessing polar membrane, from the poles of whole cells of $\underline{C}$. jejuni. This process was found to occur by means other thain the normal. septation described by Burdett and Murray, (1974) and Adler, et al. (1967) and was thought to be enhanced by the rigidity of the cytoplasmic membrane in the region of the polar membrane 
such that the tugor change likely in formation of these structures would allow an inward curvature of the membranes making the central contact and annealing more - Iikely.

The nature of polar membrane was found, by histochemical staining, to be expressed as $\mathrm{Mg}^{2}+$-dependent ATPase activity in appropriate locations, i.e.. at the poles of the cells and in localized patches along the inner surface of the cytoplasmic membrane in spheroplasts of this organism. A study of ATPase activity in $A$. serpens MW5, by histochemical staining, showed a $\mathrm{Ca}^{2+-d e p e n d e n t ~ A T P a s e}$ activity associated with the polar membrane regions. This suggested that while polar membrane is structurally similar in mainy lophotrichous Gram negative bacteria its biochemical properties may differ.

The isolation of a $\mathrm{Mg}^{2+-d e p e n d e n t ~ A T P a s e ~ f r o m ~} \underline{C}$. jejund was accomplished and, it had the biochemical characteristics of an $F_{1}$-ATPase. Futher work is required in this area. Antibodies prepared against this enzyme were shown to localize (by immunoelectron microscopy) in the polar regions of the cells near to and sometimes on the polar membrane structure. This study sugBested that polar membrane, was an array of a $\mathrm{Mg}^{2}+$-dependent ATPase. It was hypotheșised that minicell formation was. 
facilitated by the presence of the polar membrane structure and. provided a methód by which the cell could. by fortunate accident. rid itself of an energy requiring apparatus.

The study of the antigenic relationship of this ATPase to those from other bacterial genera and rat liver mitochondria showed, again, that biochemical differences may exist between the components of polar membrane in difierent organisms and that the ATPase of $\underline{\underline{C}}$ desund and M. voltae appear to have evolved aiong different pathways. to those of E. celi and mitochondria.

The presence of polar membrane in a variety ot bacterial genera, as well as the seeming conservation of different antigenic specificities, pose some interesting phylogenetic questions. It is possible that a more detailed.study of this structure in other organisms may lead to a greater understanding of the phylogeny of the organlsms possessing polar membrane. A study of the ATPase activity of polar membrane in different organisms - may also provide valuble insight into the conservation of the active units of this metabolically important enzyme and begin a more productive look at the differences of F1-ATPases rather than the persistent search for homologies within this enzyme group. 
8: :

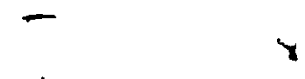

$->$

Figure I: Diagram of the polar membrane in

Ectothiorhodospird mobilis. (Erom

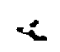

Remsen, etal.. 1968).
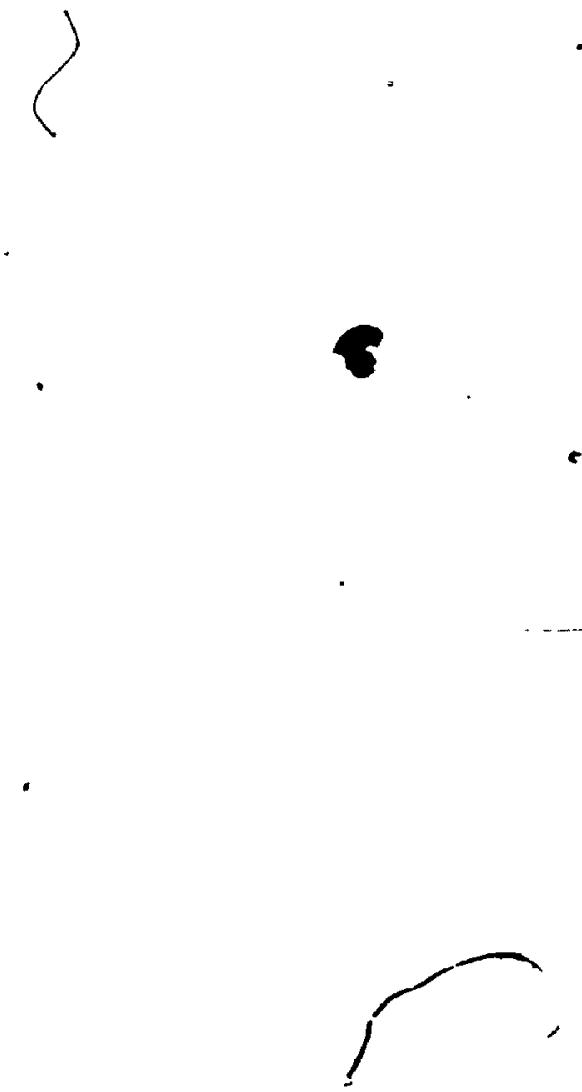
- Figuré 2: Conceptual model of Fofl of Escherichia coli. This model was drawn based on reconstitution experiments, subunit stoichiometry, predicted secondary sures, and subut interactions. This model is not drawn to scale. Lettering of subunits is described in the text. 

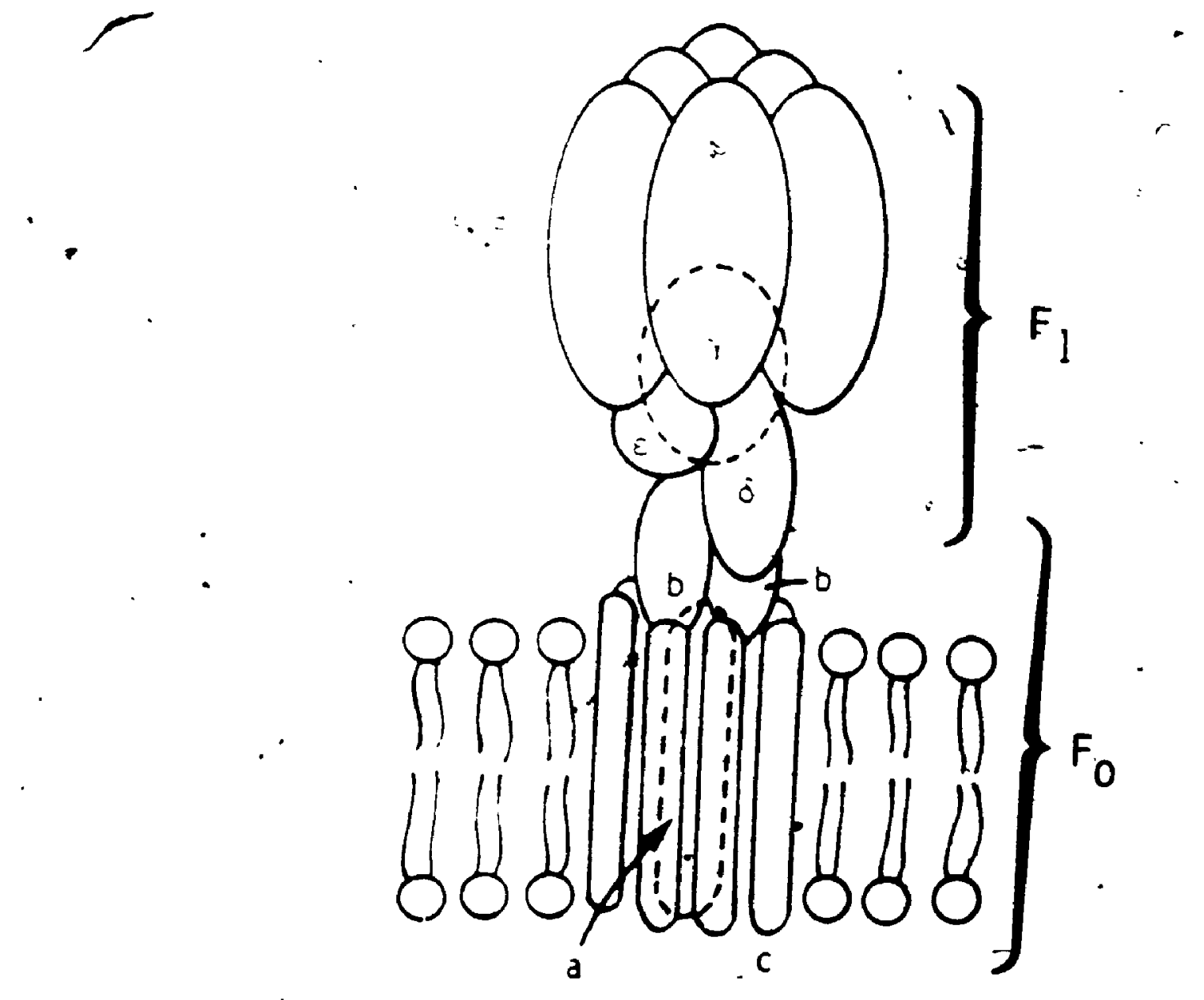

- 1 
$\because:$ :

1

,

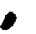

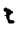

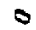

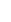

-

Figure 3: Growth. curve for $\underline{c}$. jejuna grown in $500 \mathrm{ml}$ - volumes of Brucella broth (Difco) without shaking at $400 \mathrm{C}$.
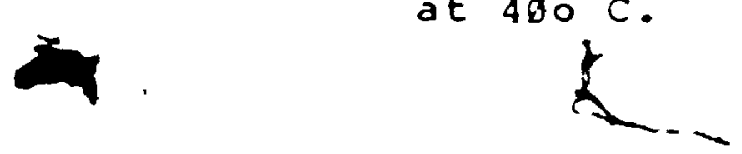

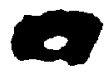


-

181

4

,

.

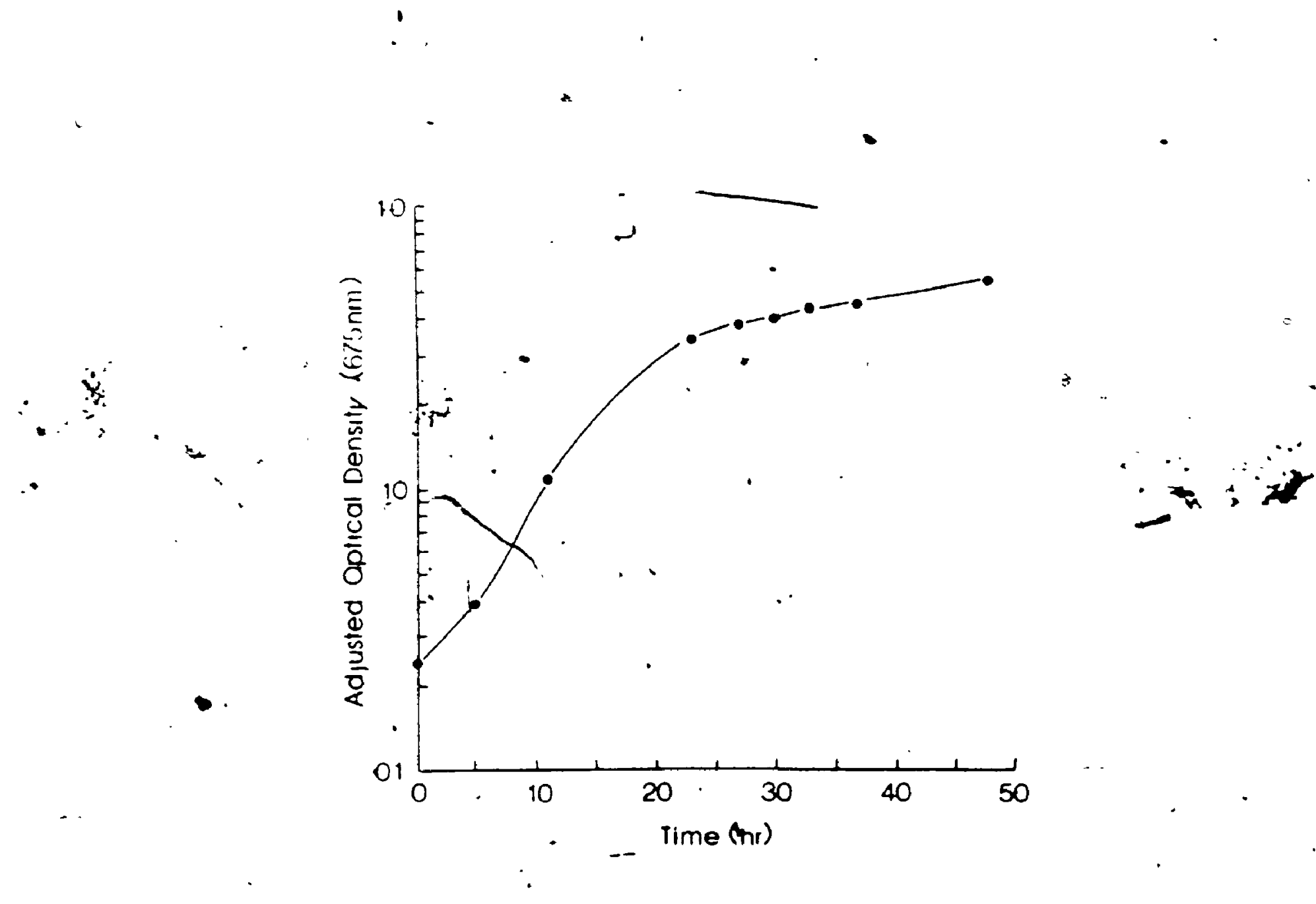

-

,

.

' 
$\therefore: \quad+2$

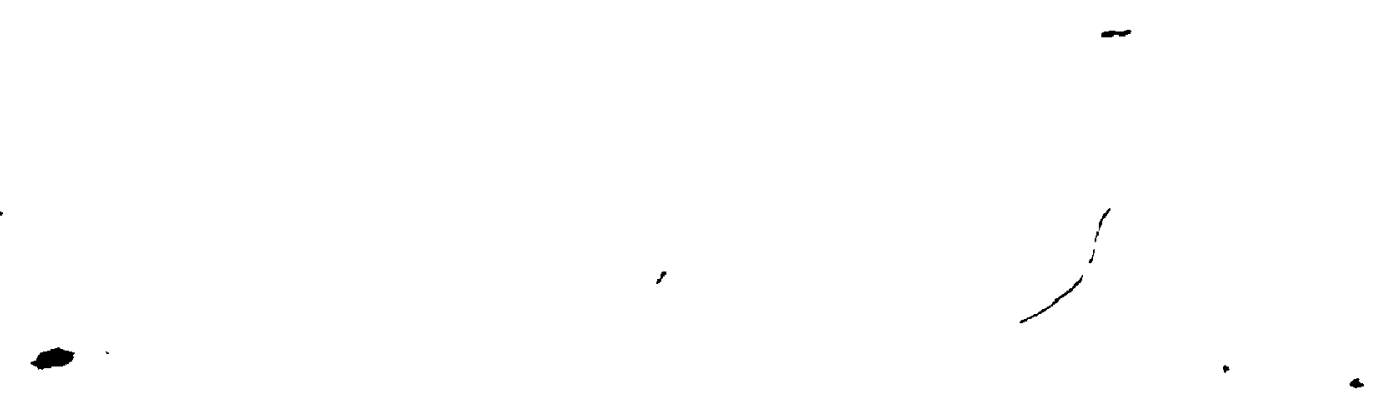

Figure 4 : Thin section of $\underline{C}$. jejuni, fixed with 58 acrolein and 0.258 ilutaraldehyde in $0.05 \mathrm{M}$ cacodylate buffer ( $\mathrm{PH} 7.5$ ) and stained with 18 iranyl acetate (aqueous) and Reynolds lead citraEe, showing the cytoplasmic membrane (CM), polar membrane (PM), outer nembrane (OM), polar Elagellum (f), ribosome free area (RF), and spherical inclusion bodies (SI). Bar $=100 \mathrm{~nm}$.

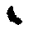

1 


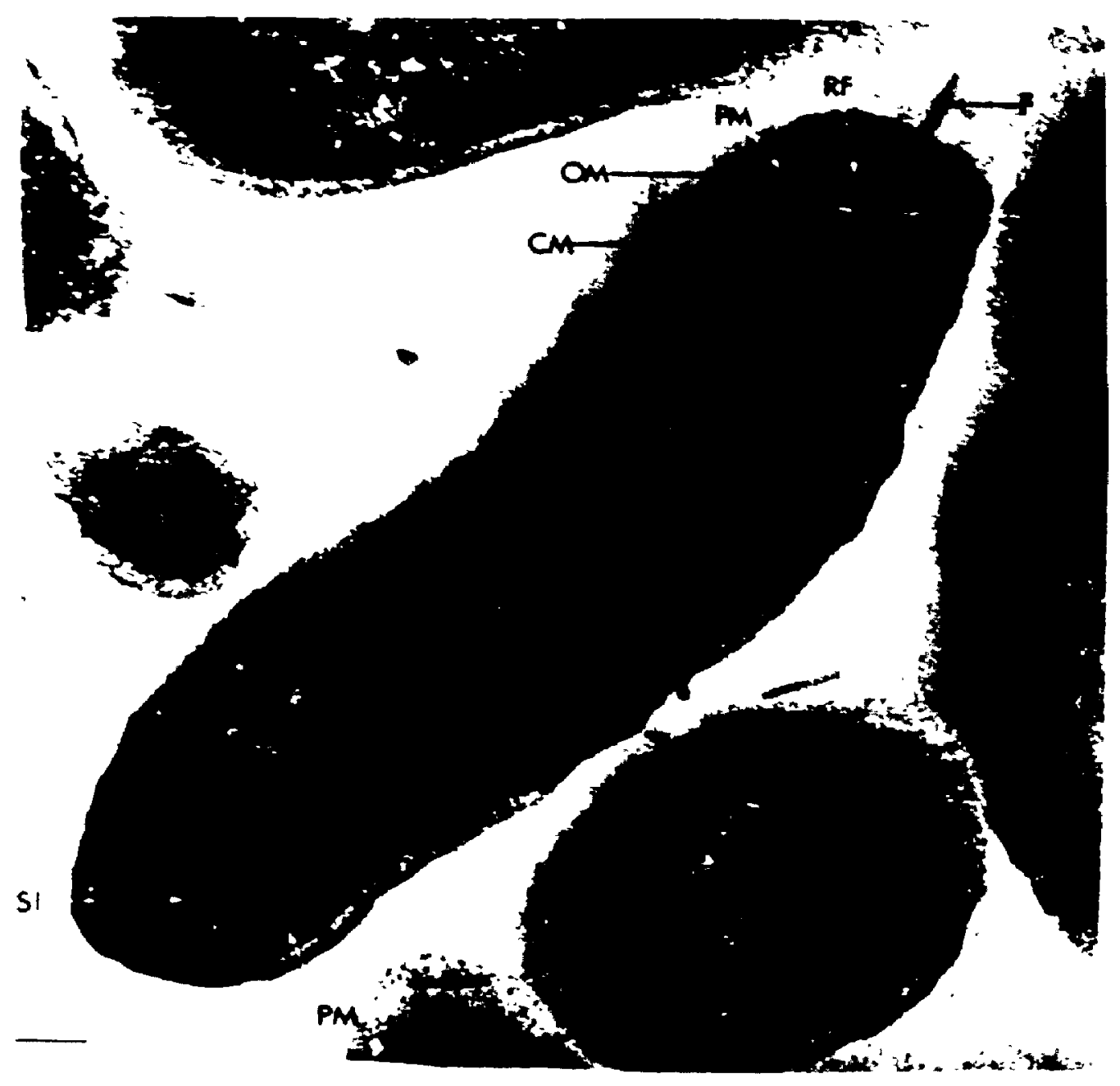


Figure 5: Thin section of $A$. Serpens MW5 fixed with 58 . acrolein and $0.25 \%$ glutarakdehyde in $0.05 \mathrm{M}$ cacodylate buéfer ( $\mathrm{pH} 7.5$ ) and stained with 18 uranyl acetate (aqueous) and Reynolds lead citrate, showing cytoplasmic membrane (CM). polar membrane (PM), outer membrane (OM). peptidoglycain ( $P G)$, and $r$ ibosome free area (RF). Bar $=100 \mathrm{~nm}$. 


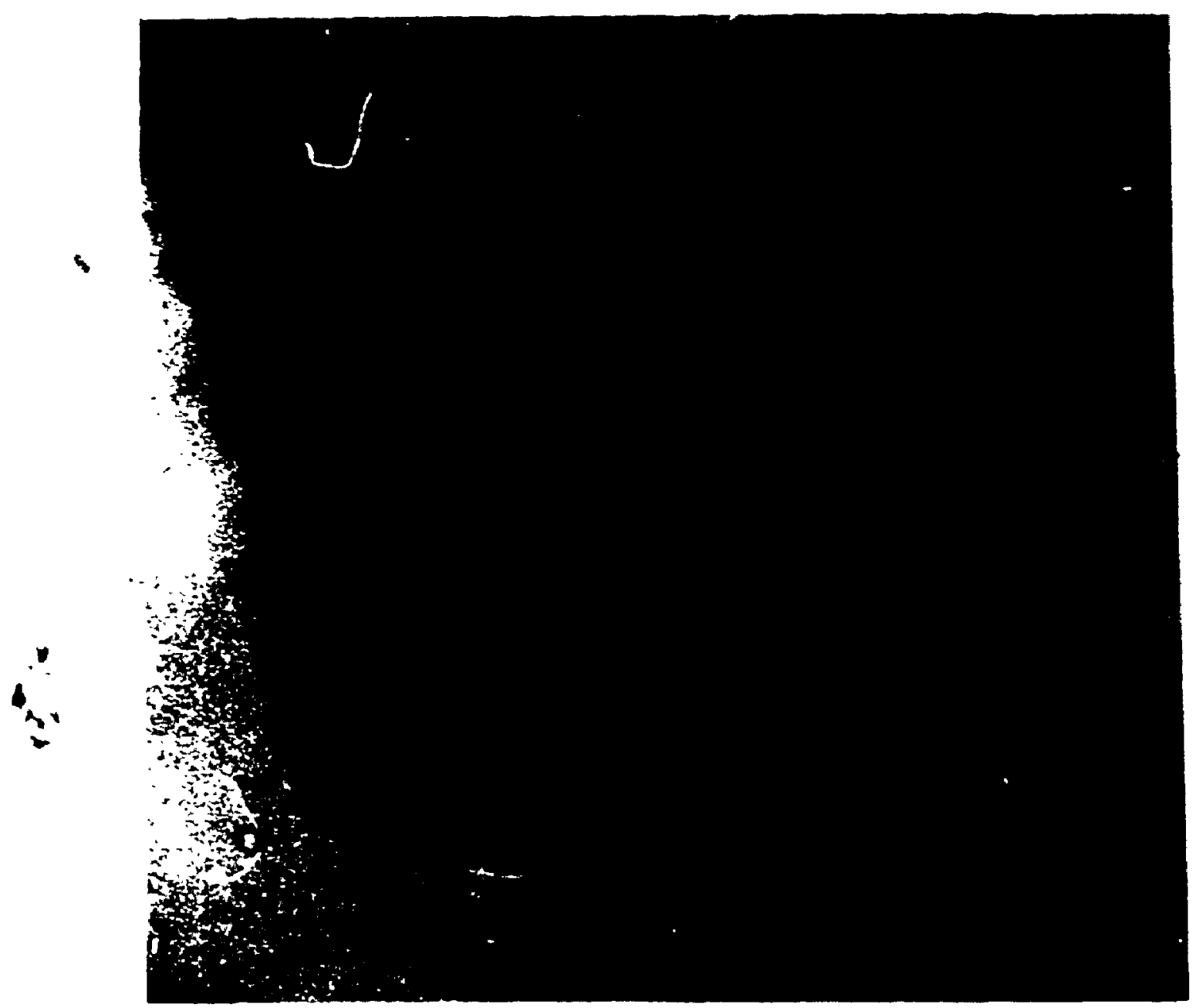


Q.

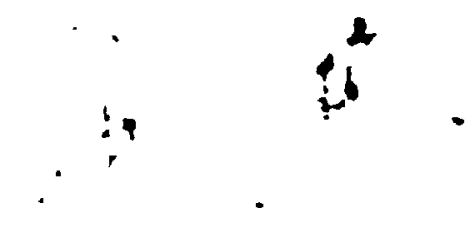

Figure 5: Cross section of C. jejuni Eixed and stained as in Fig. 4, showing polar membrane (PM) lining the inner surface of the cytoplasmic membrane $(C M)$. OM, outer membrane. Bar $=100 \mathrm{~nm}$.

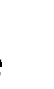




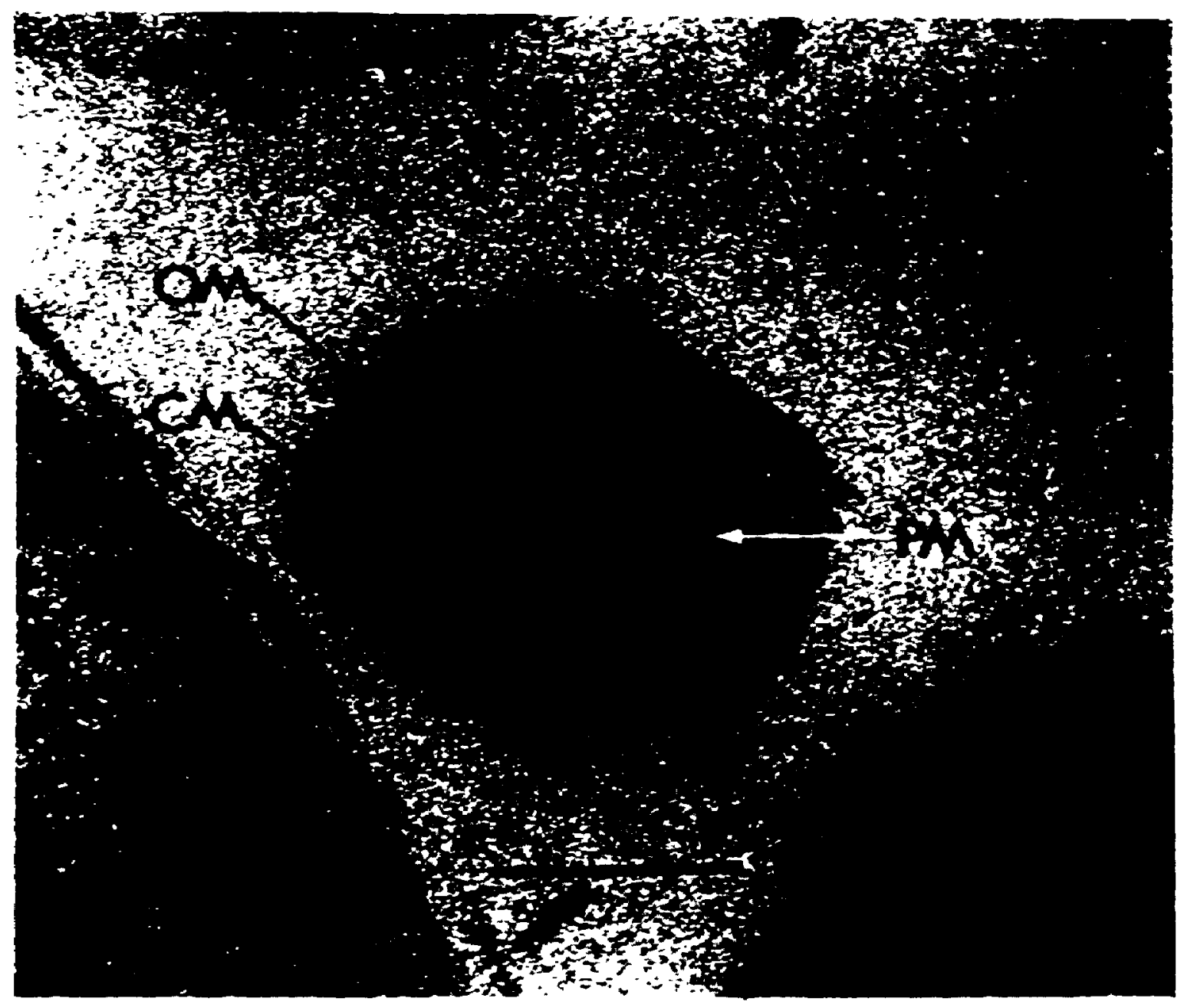




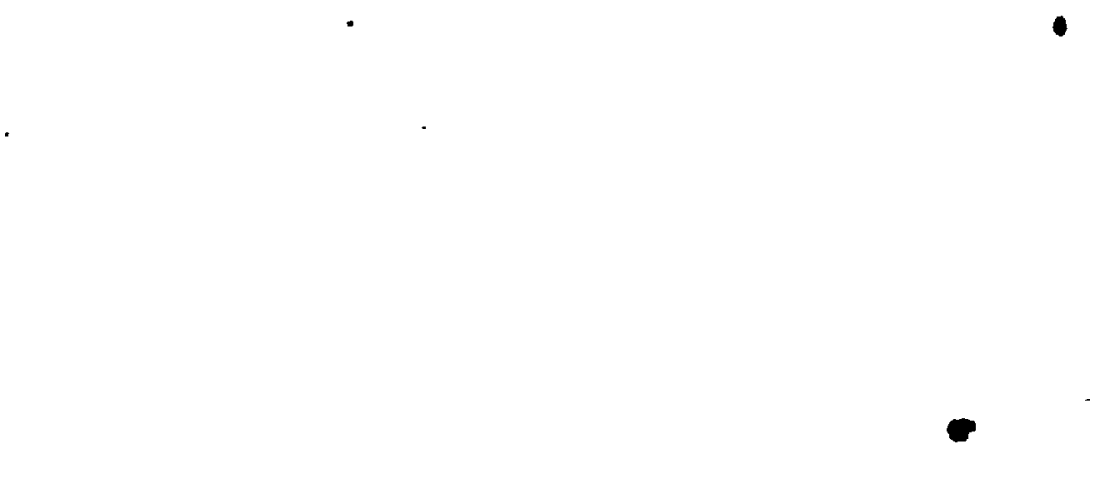

Figure 7: Cross section of $A$. serpens MW5 fixed and rstained as in Fig: 5 , showing patchés of polar membrane (PM) on the inner surface of the plasma memorane. OM, outer membrane; PG, peptidoglycan; RS, regular structured array. $B a r=100 \mathrm{~nm}$. 


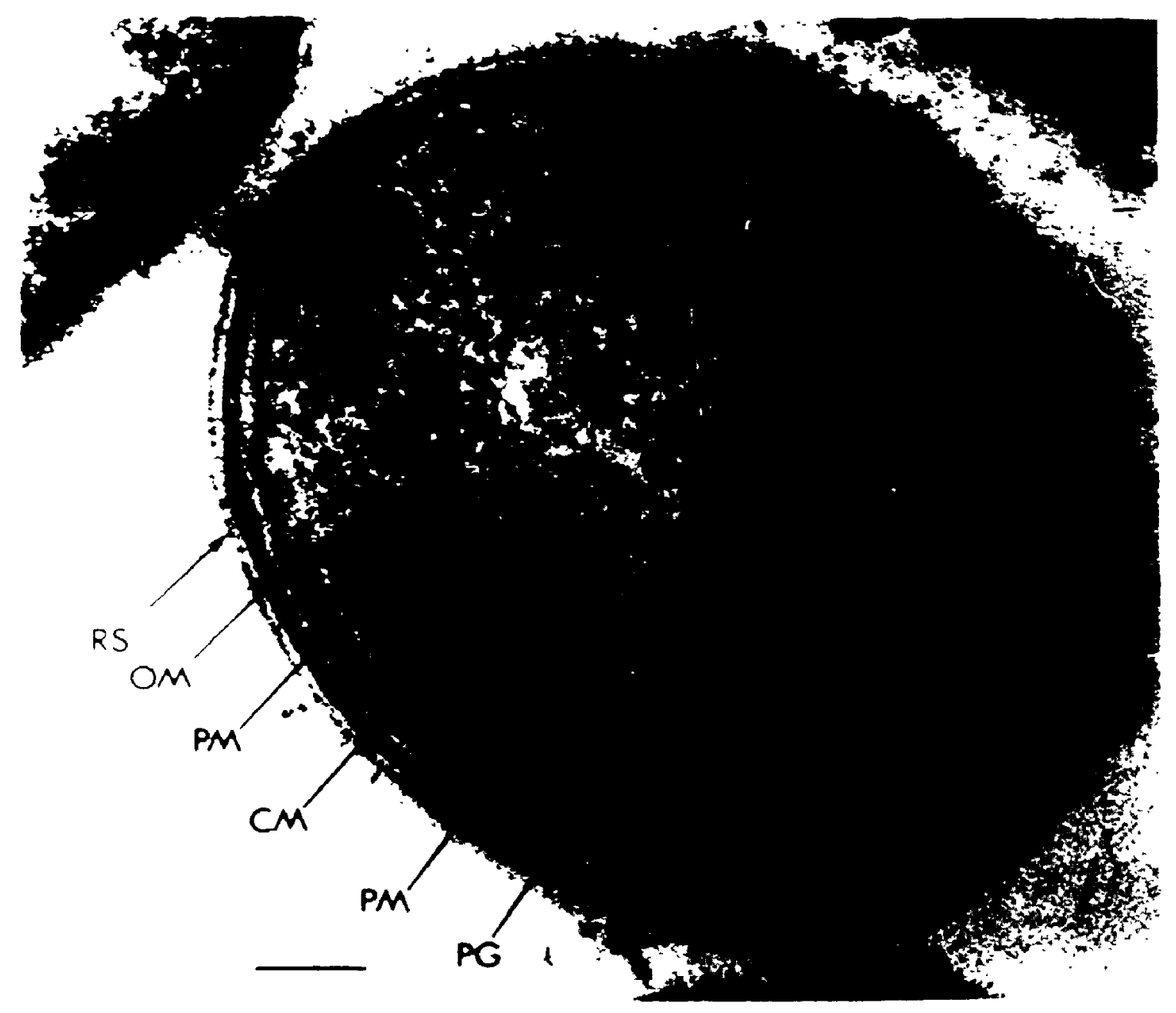


6:2.

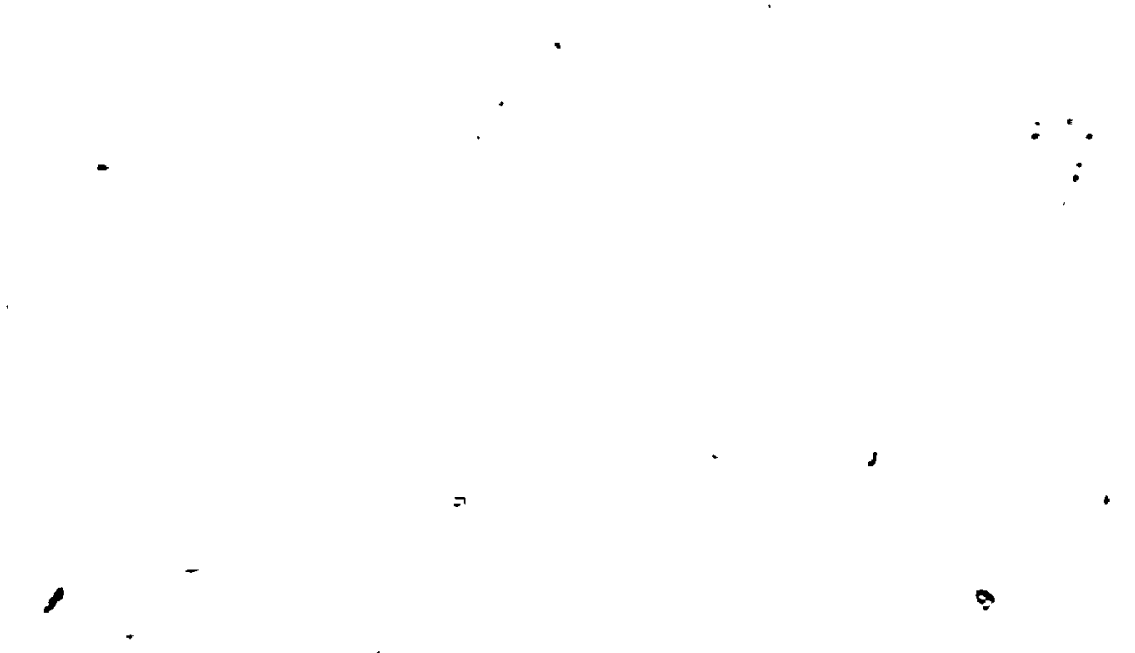

Figure 3 : Thin section of $C$. jejuni Eixed and stained as in Fig. 4, showing septum (S) between two daughter cells and polar membrane (PM) Iining the cytoplasmic membrane (CM). Bar $=100 \mathrm{~nm}$. 


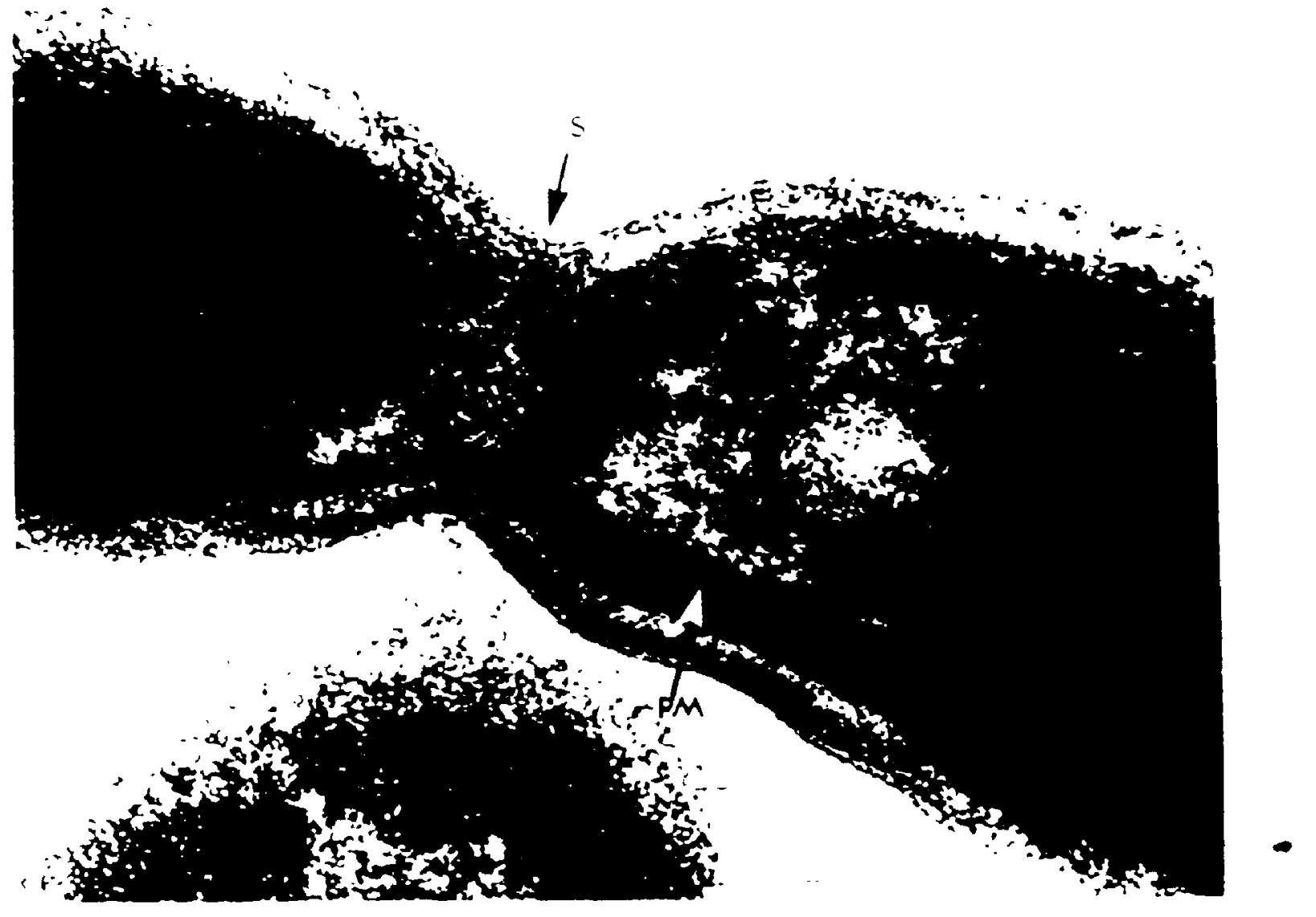




\section{$\because$}

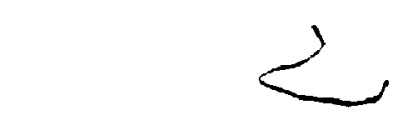

Figure 9: Thin section of a dividing $\subseteq$. jejuni cell, showing a normal septum (S) and no visible polar membrane on the cytoplasmic membrane at this site. Polar membrane $(P M)$ is violble at the opposing end of one daughter cell. Bar $=100$ $n \pi$. 


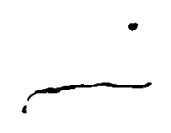

.

Figure 10: Thin section of a polar region of $\underline{c}$. jejuni. showing association of polàr membrane (PM) with the flagellar basal complex and the $M$ ing (M), and fibrous material (FM) of the basal complex. oM, outer membrane; $C M$, cytoplasmic membrane. Bar $=100 \mathrm{~nm}$. 


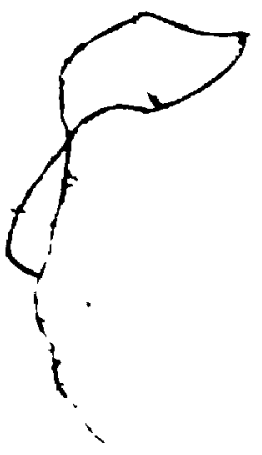

Figure II: Thin section of the polat region of $\underline{c}$. jejuni showing the association of polar membrane (PM) to the flagellar basal complex and the concentric membrane rings (CMR), $P$ ring ( $P$ ), and the $M$ ring $(M)$ of the basal complex. F, flagellum. Bar $=100 \mathrm{~nm}$. 
$02:$

-Figure 13: Thin section of the polar region of $\underline{c}$ : jejuna showing the association of polar membrane (PM) to the flagellar basal complex and the M ring (M), concentric membrane $t$ ing (CMR), and the $P$ ring (P). Bar $=100 \mathrm{~nm}$. 
Figure 14: Thin section of the polar region of $C$ - jejuni showing the association of polar membrane (PM) to the Elagellar basal complex (FB). RE, ribosome Eree area; SI, spherical inclusion body. Bat $=100 \mathrm{~nm}$. 
Figure 15: Thin section of the polar region of $c$. jejuni showing the association of polar megbrane (PM)
to the flagellar basal fomplex. CMR,
concentric membrane rings: RF, tibosome free
area. $3 a r=100 \mathrm{~nm}$.

4 Figure 15: 


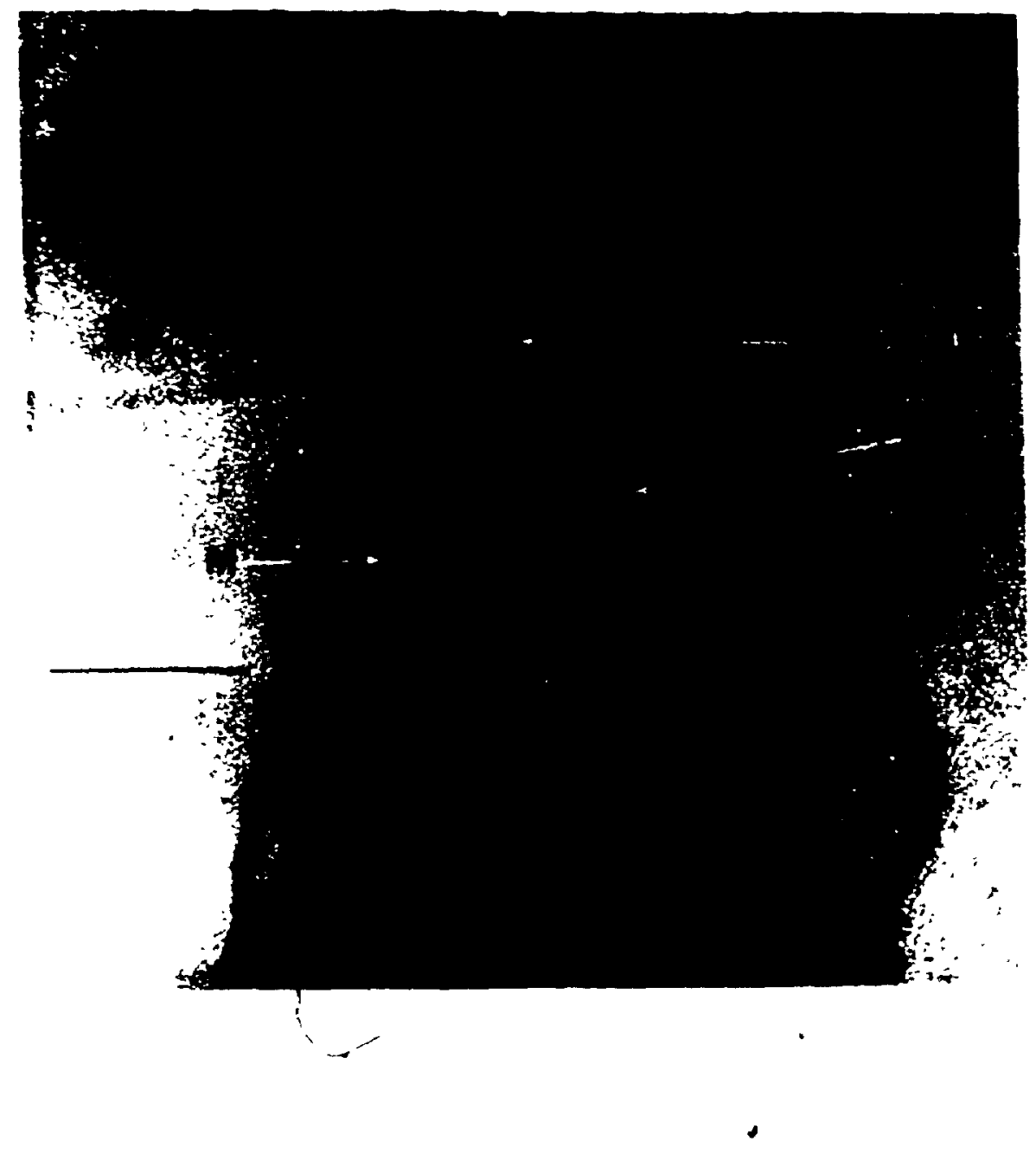


a. : :

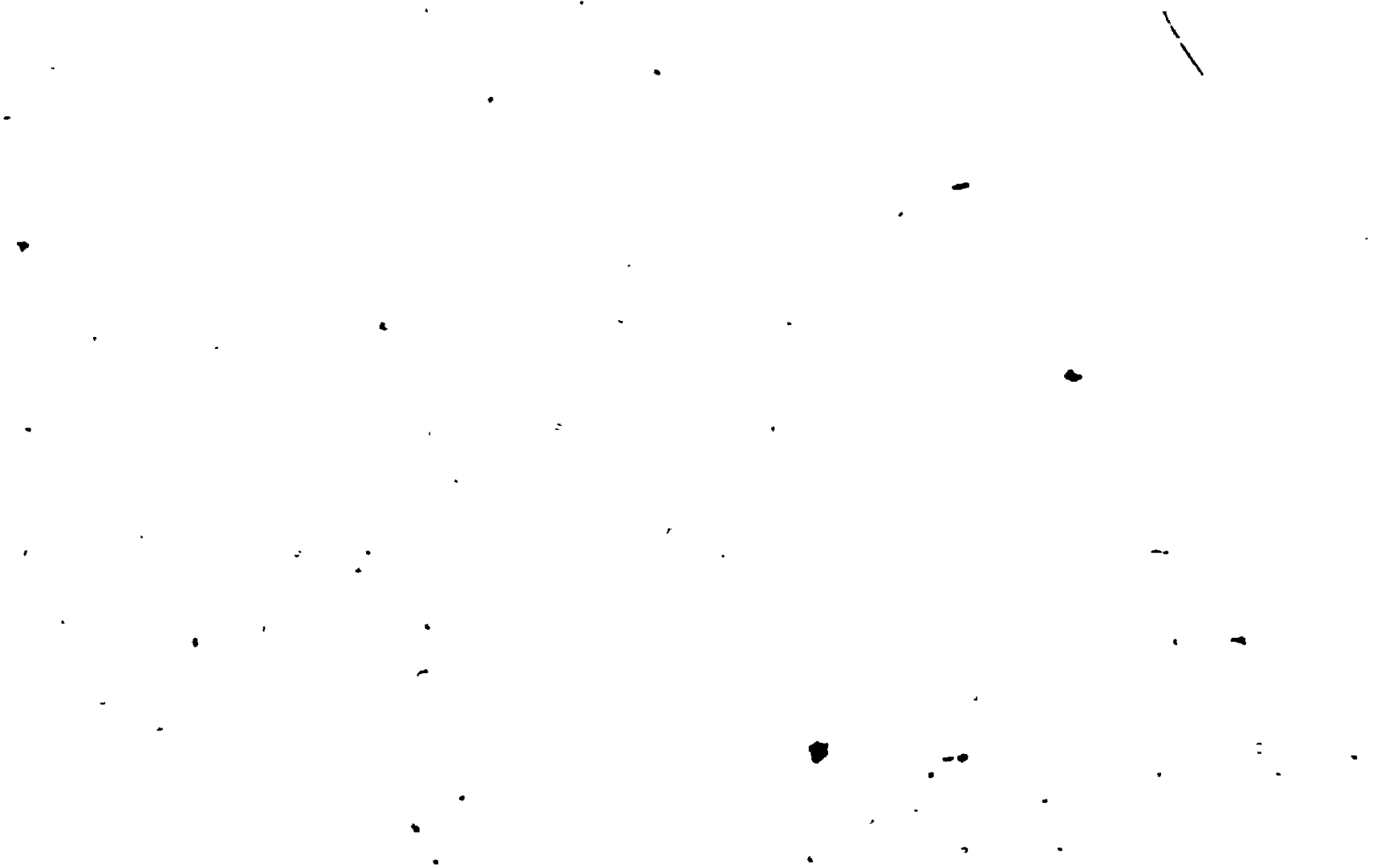

Figure 15: Longitudinal and cross section of $\underline{c}$. jejuni showing polar merbrane (PM) and the rigid $\rightarrow$ cytoplasmic membrane (RCM) associated with the structure. Bar $=100 \mathrm{~nm}$. 
Figure 17: French.pressure cell jistupted membrane preparation of $\subseteq$. jejuni negatively stained with 18 phosphotungstic acid (pH 6.8) . 17a, shows dough-nut shaped particles (arrow) associated with a membrane fragment from the polar region as denoted by the presence af a flagellum (E). 17b, shows a intact polar vesicle with dough-nut shaped particles (arrow) on the inner nembrane. Bars $=100 \mathrm{~nm}$. $\therefore$ 
$\rightarrow$

Figure 18: French préssure céll disrupted membrane preparation of $\subseteq$ : Jejuni negatively stained with 18 phosphotungstic acid (pH 6.8) showing an enclosed membrane vesicle with dough-nut shaped particles (arrow) associated with the internal membrane of the vesicle; the outer enclosing membrane contains a concentric membrane ring (CMR) denoting it as outer membrane from the polar region of the cell. - $\mathrm{Bar}=100 \mathrm{~nm}$. 
Figure 19: Negatively stained memorane preparations of $C$. jejuni. 19a, membranes prepared in a high ionic strength buffer plus $2.5 \mathrm{~mm}$ 2-mercaptoethanol showing hexagonally arranged dough-nut shaped particles (arrow). 19b. membranes prepared by the modified monolayer technique of Nermut (1983) showing hexagonally arranged dough-nut shaped particles (arrow). 190 , and 19d, membranes delipidated with 18 cholic acid, showing fine hexagonal arrays (arrows) in flattened membrane sheets. Bars= $160 \mathrm{~nm}$. 



\section{a :?}

• 


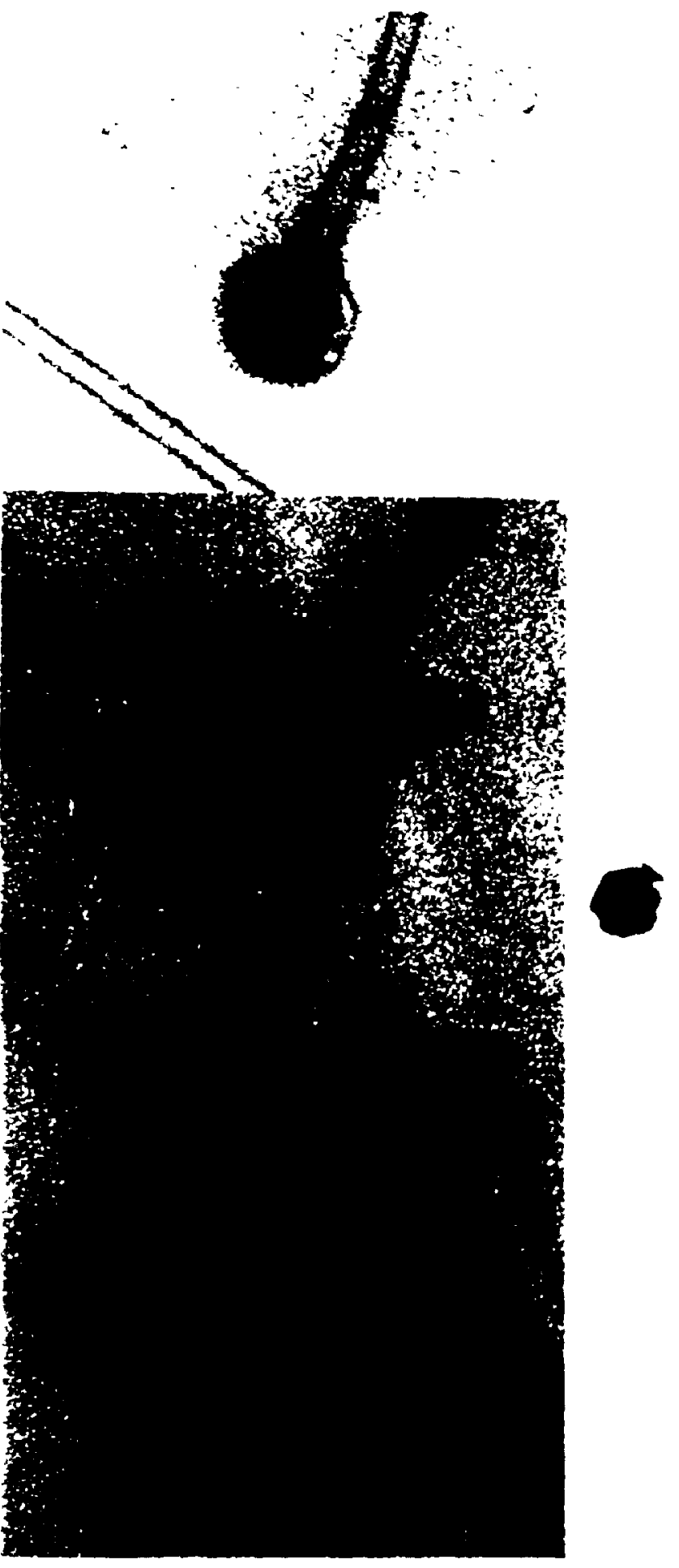




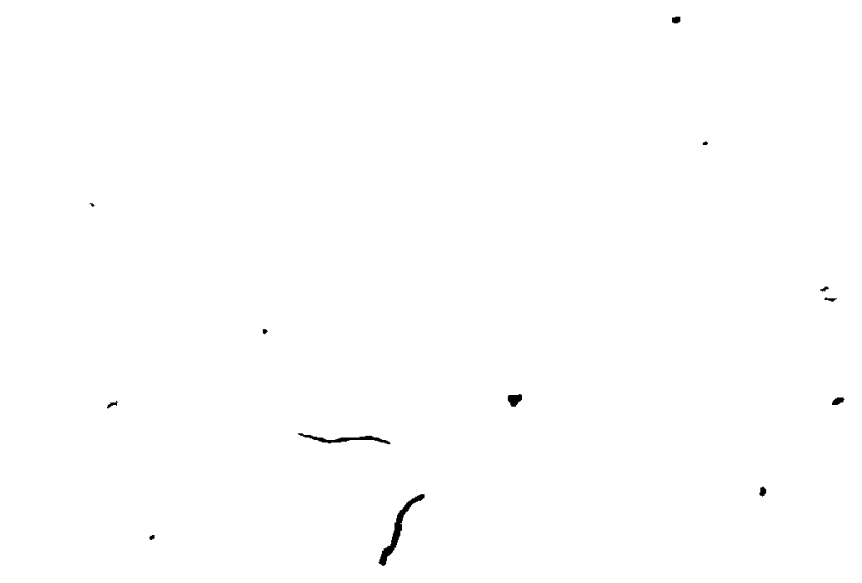

Elgure 22: Thin sections of minicells from $c$. jejuni.

OM, outer membrane; CM, cyroplasmic membrane;

PM, polar membrane. Bar $=100 \mathrm{~nm}$.

1

$a$

I

$\therefore$

) 


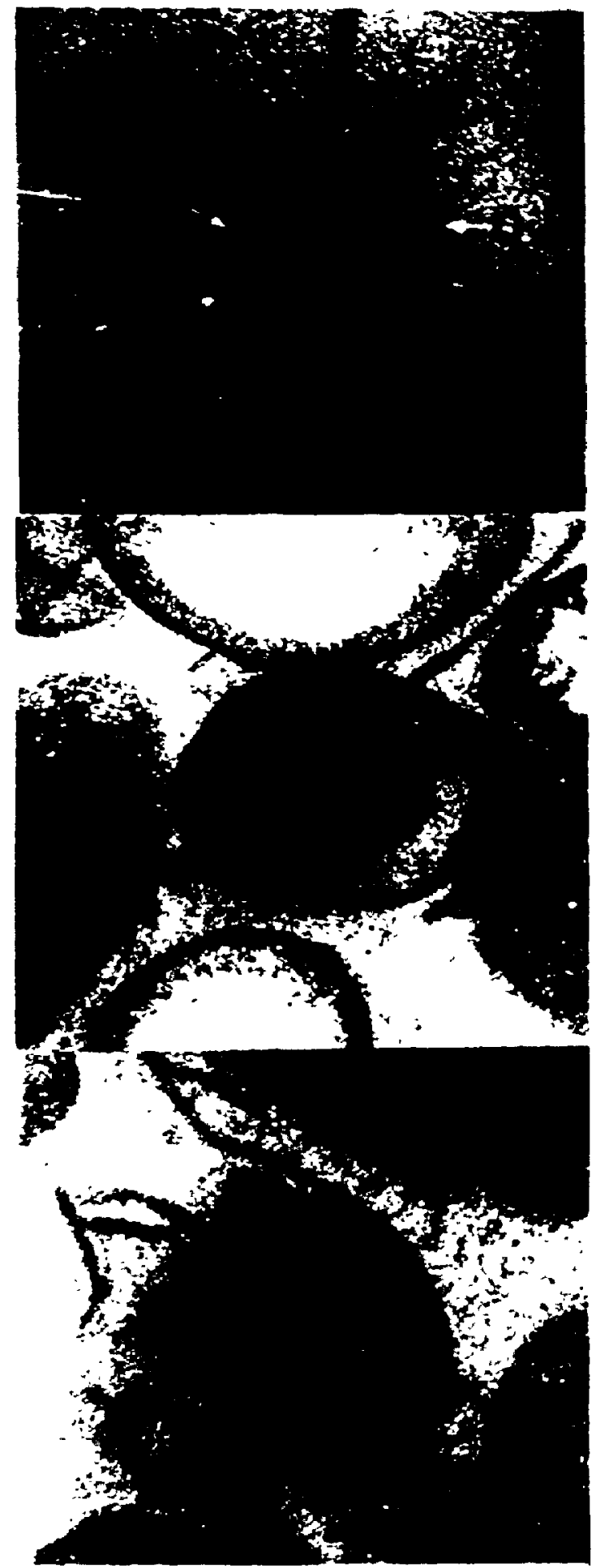


0?:

Figure 23: Thin sections of $\underline{c}$. jejune showing formation of minicells. 23 (1) to. (4) shows increasing. constriction of the cytoplasmic membrane resulting. in segregation of the polar regions “ of the cells. Bar $=10 \dot{0} \mathrm{~nm}$. 
39

- Figure 24: Negatively stained whole cell of ́ $\subseteq$. jejuna,

$-$ showing a minicell forming in the polar region $(a r r o w) .0$ Bar $=100 \mathrm{~nm}$. 
is:

$\bullet$

Figure 25s Thin section of minicell preparation showing contamination with whole cells, membrane' vesicles and flagellar debris. Bar $=100 \mathrm{~nm}$. .

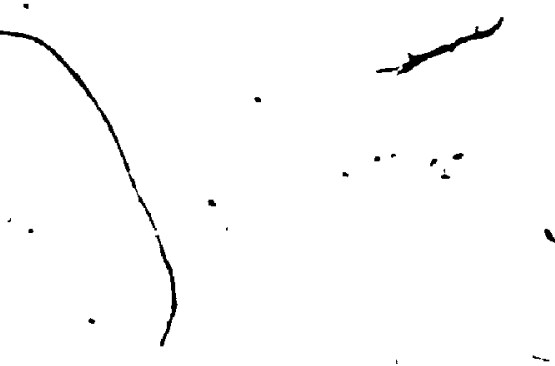




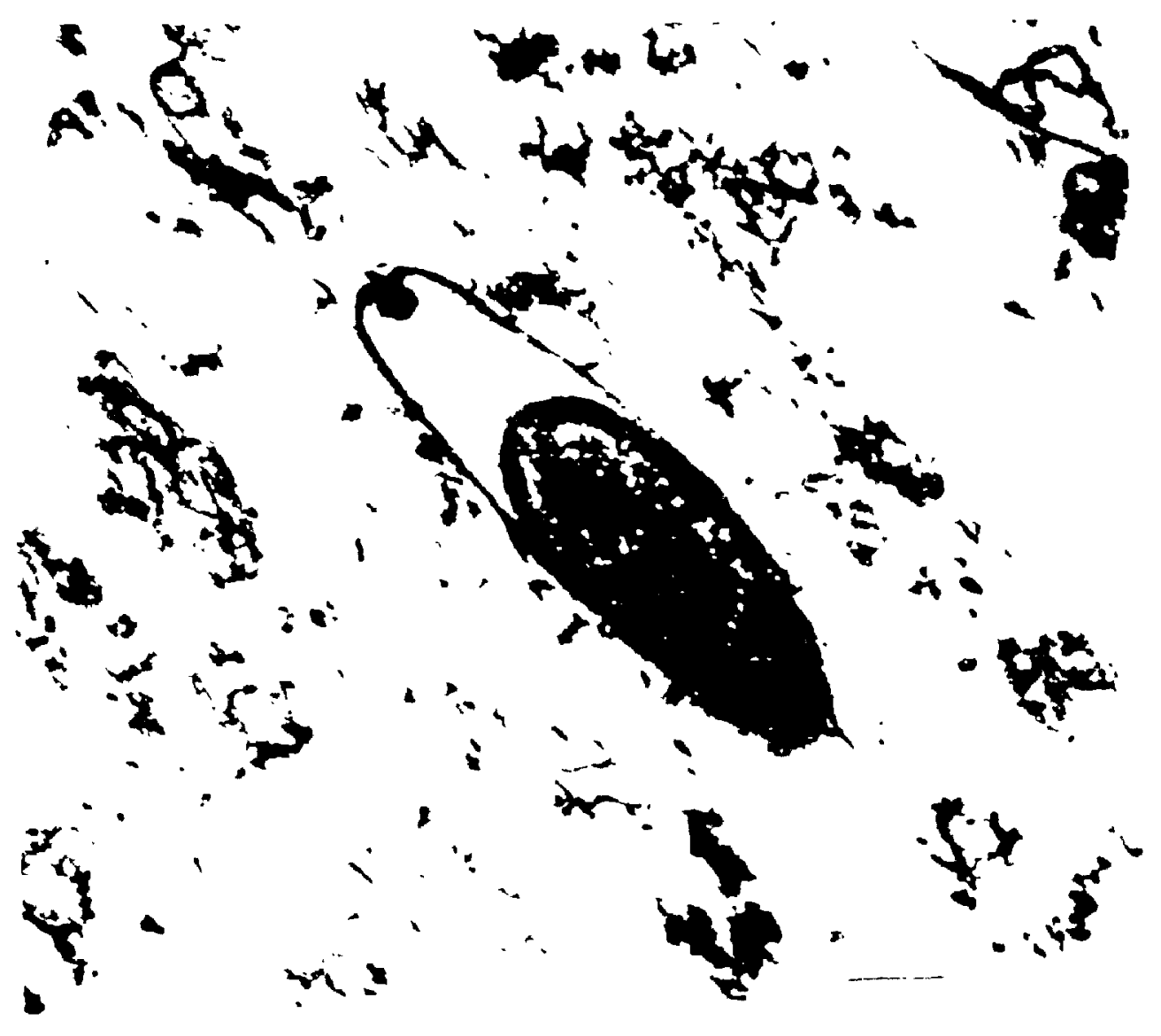


Q : ?

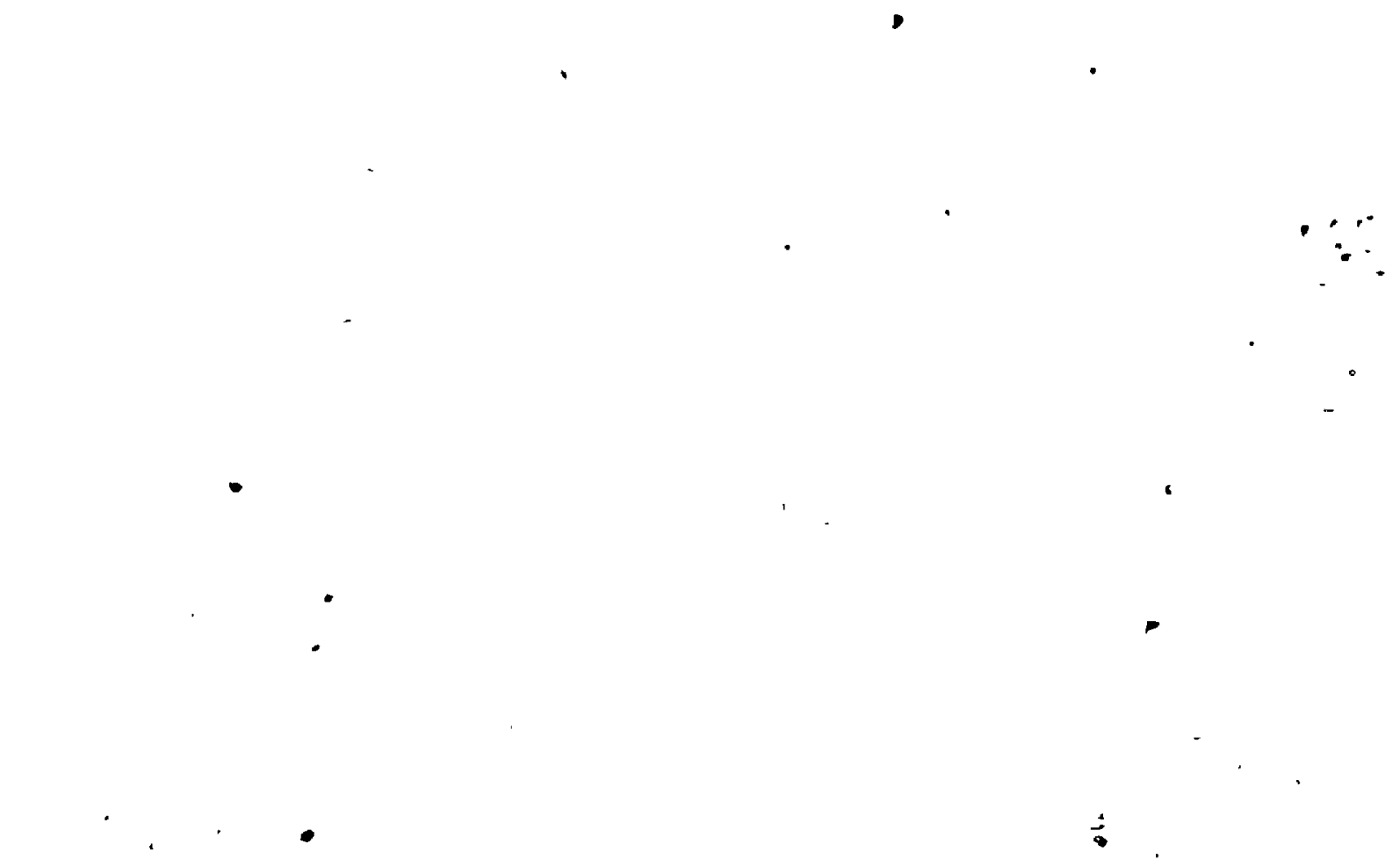

Figure 26: Negative stain of a minicell from $\underline{c}$. jejuni showing an hexagonal pattern (arrow) in the interior. Bar $=100 \mathrm{~nm}$. 



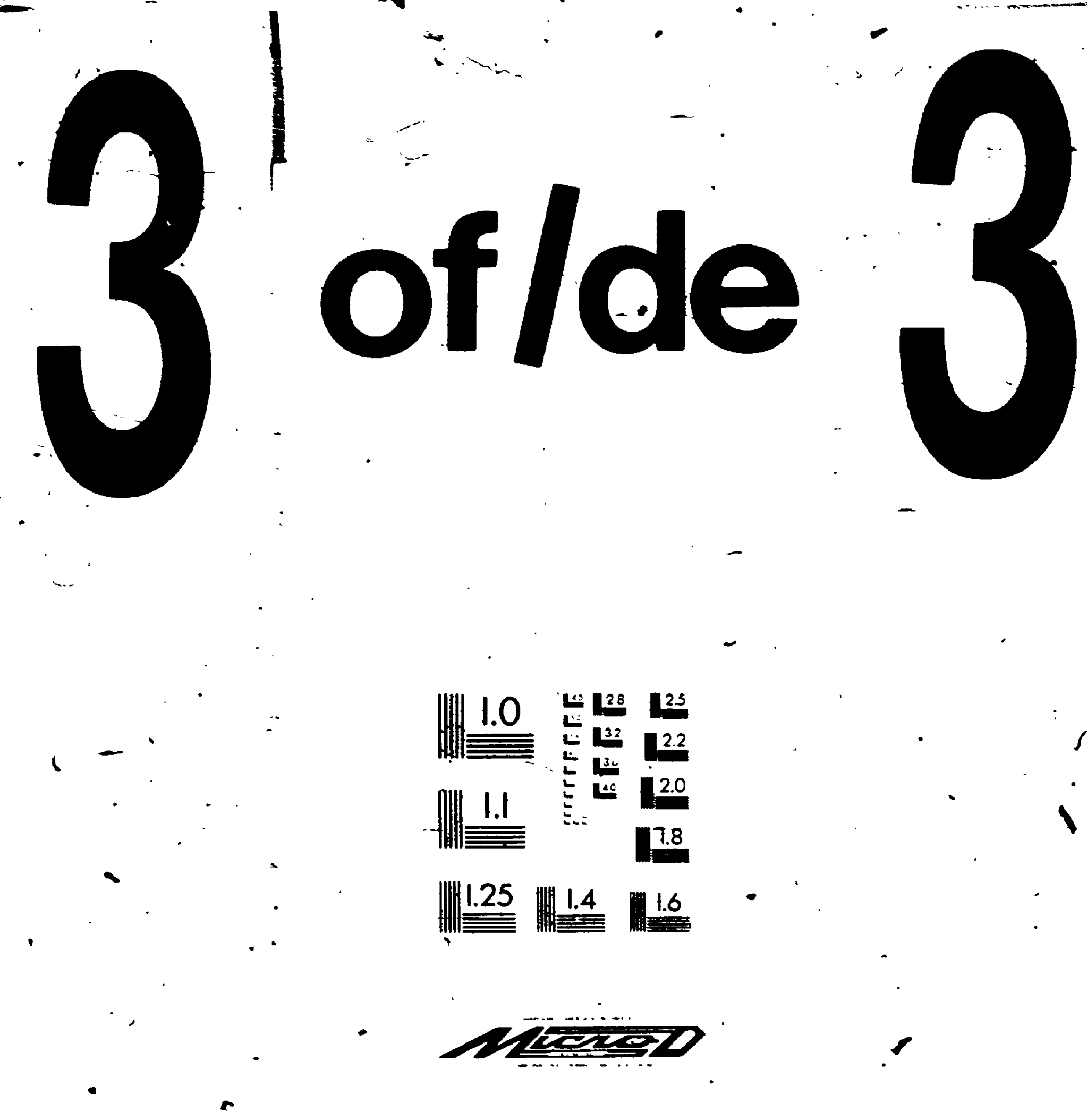

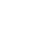

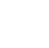




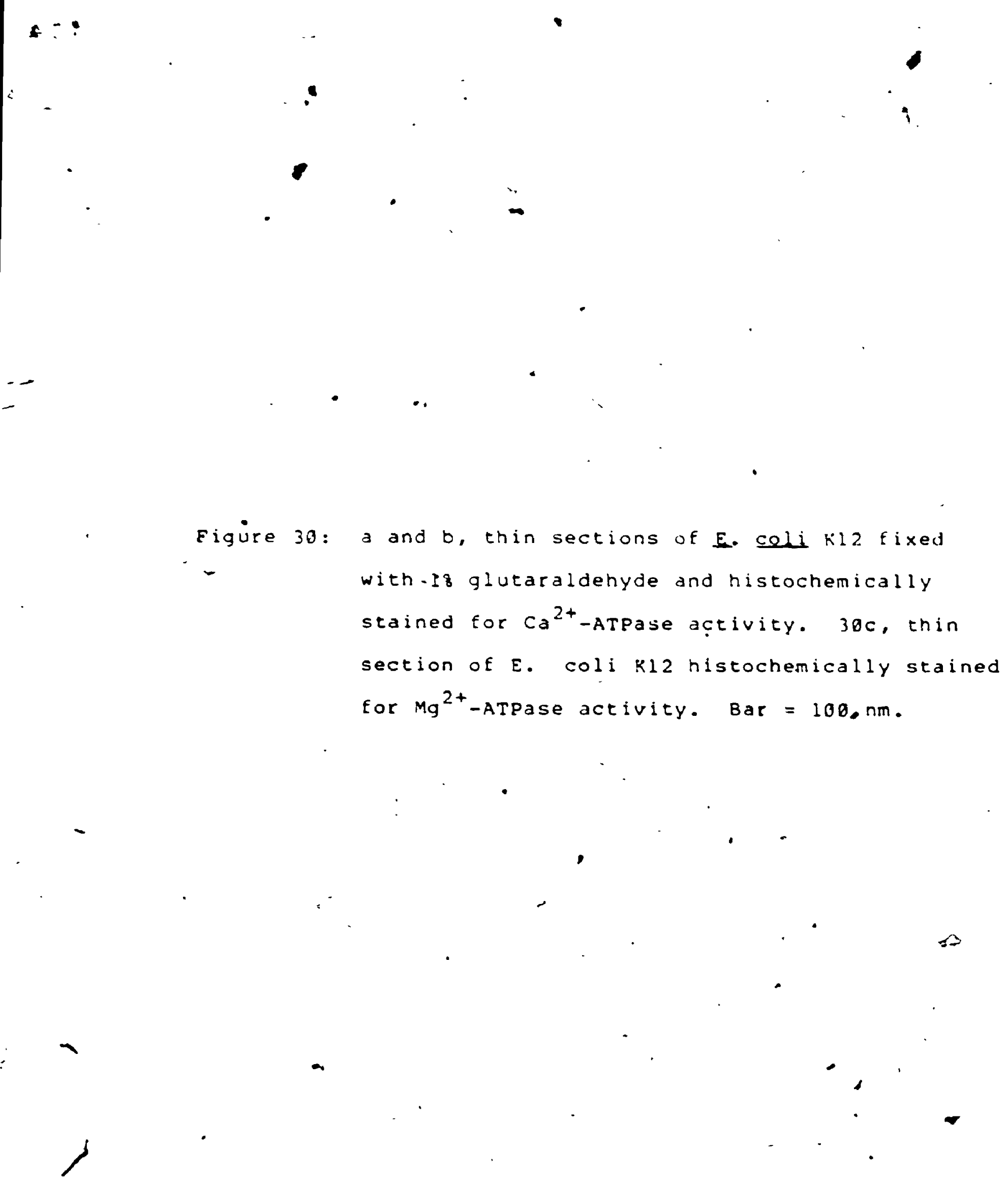



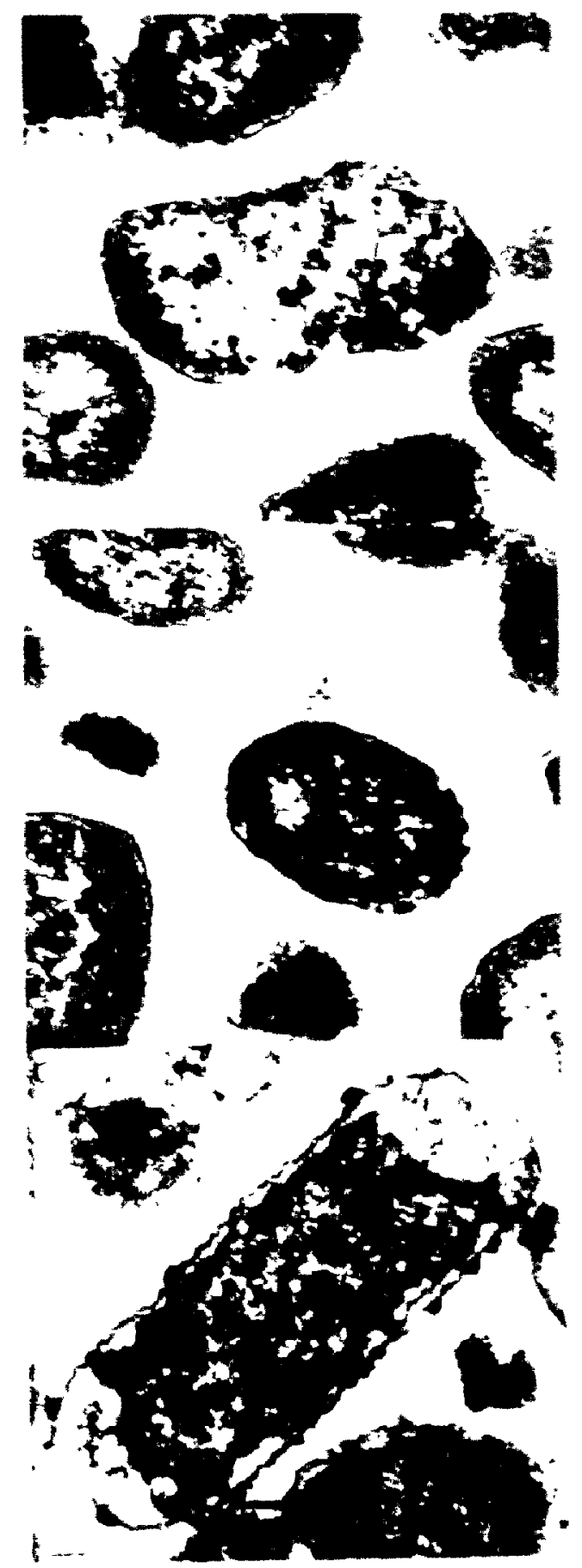


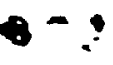

Figure 31: Thin section of $\underline{\text { B }}$ cereus fixed with 13

glutaraldehyde and histochemically stained for,. $M g^{2+}$-Atpase activity. Bat $=200 \mathrm{~nm}$.

1 


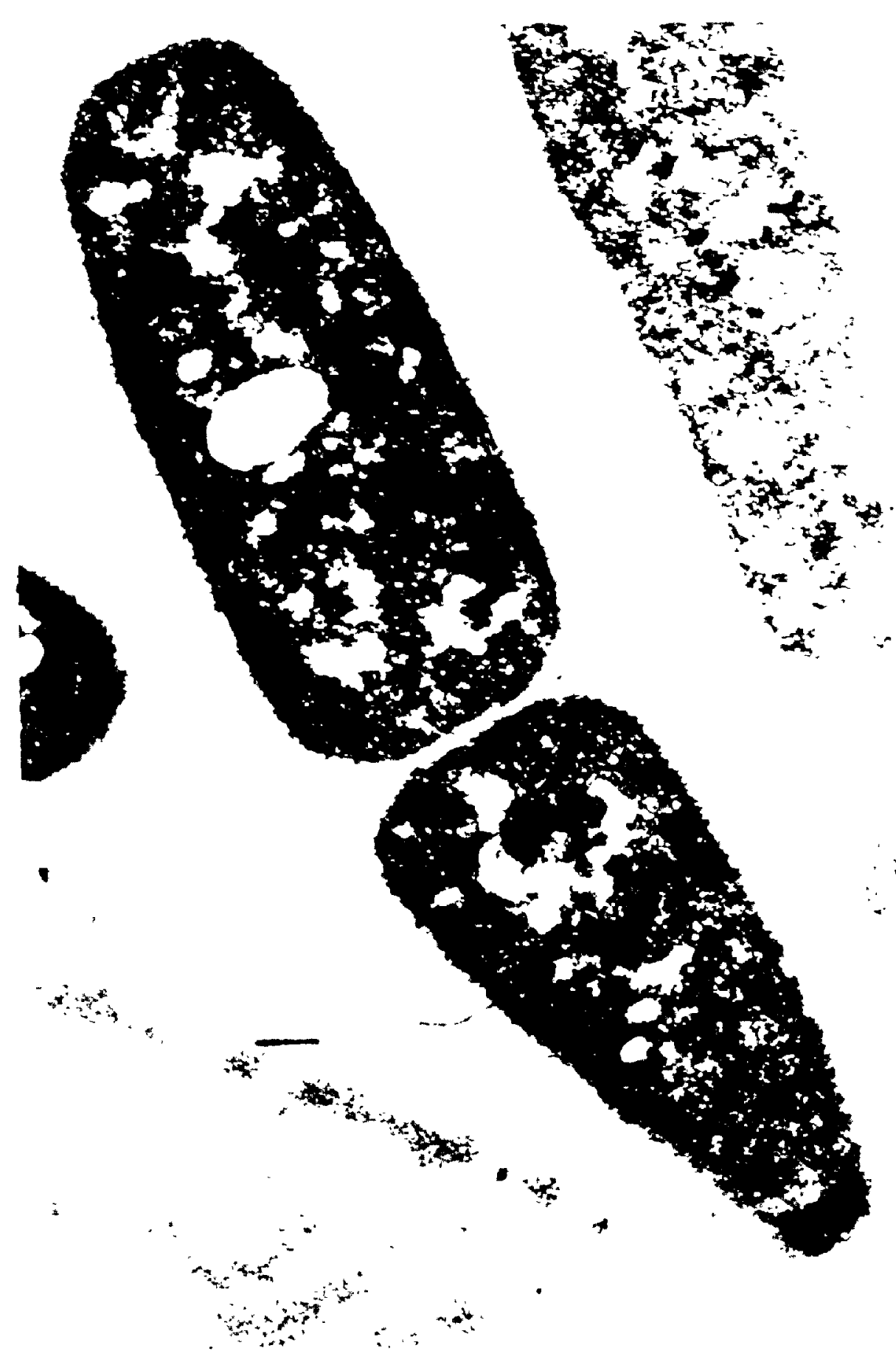




$$
\mathbf{0}
$$

2

Figure 32: Thin sectiogs of $M$. Luteus fixed with 18 glutaraldehyde and histochemically stained for

$$
\begin{aligned}
& \text { 1!. (a), Ca }{ }^{2+} \text {-ATpase adtivity and (b), } \mathrm{Mg}^{2+} \text {-Atpase } \\
& \because \text { activity. Bars }=200 \mathrm{~nm} \text {. }
\end{aligned}
$$

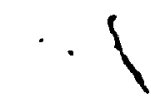

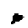

- 
$-1 \div 9$

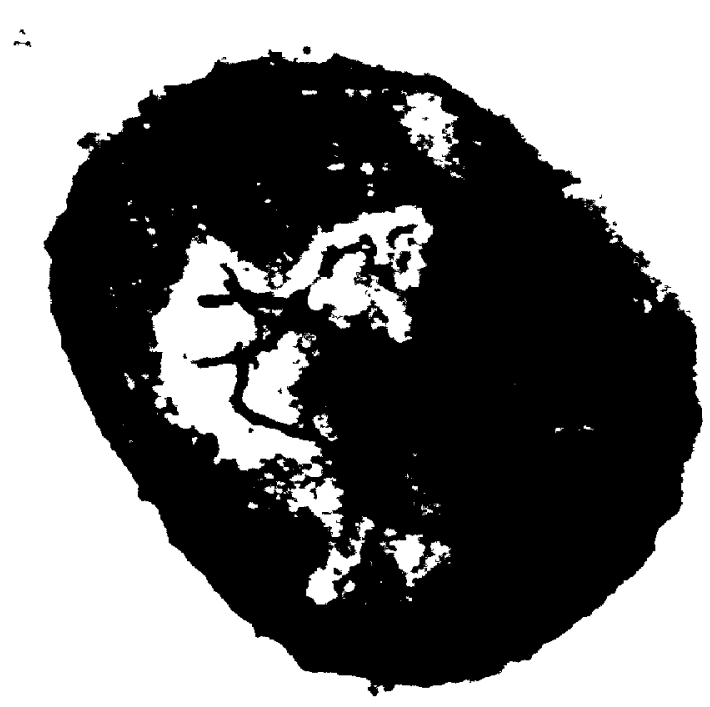

$8 * x$

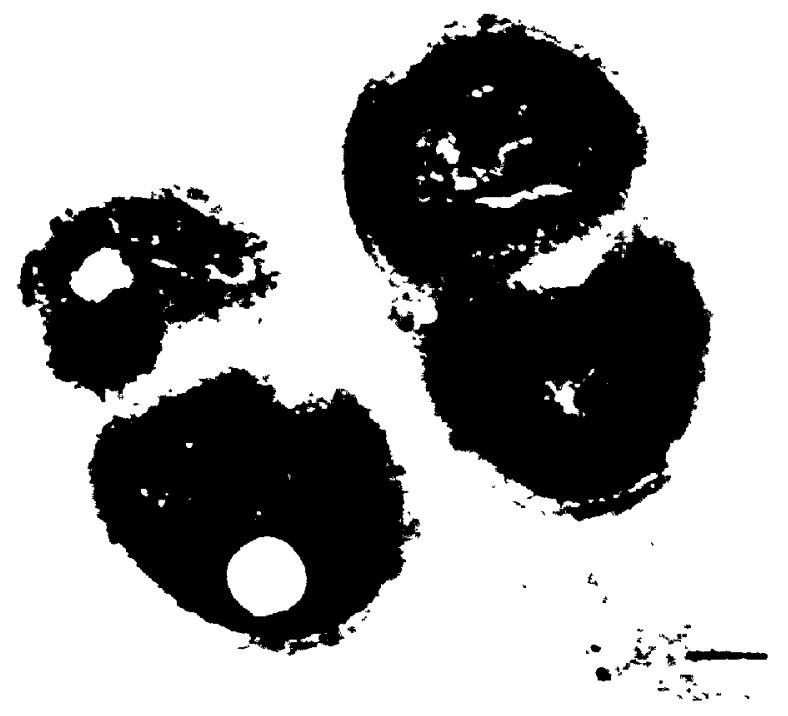



Figure 34: Thin sections of a serpens MW5 fixed with 18 glutaraldehyde and histochemically stained $\therefore$ for (a), $\mathrm{Mg}^{2+}-\mathrm{ATPa}$ se activity, and (b). $\mathrm{Ca}_{2+}$-ATpase activity. Bars $=200 \mathrm{~nm}$. 
$m$

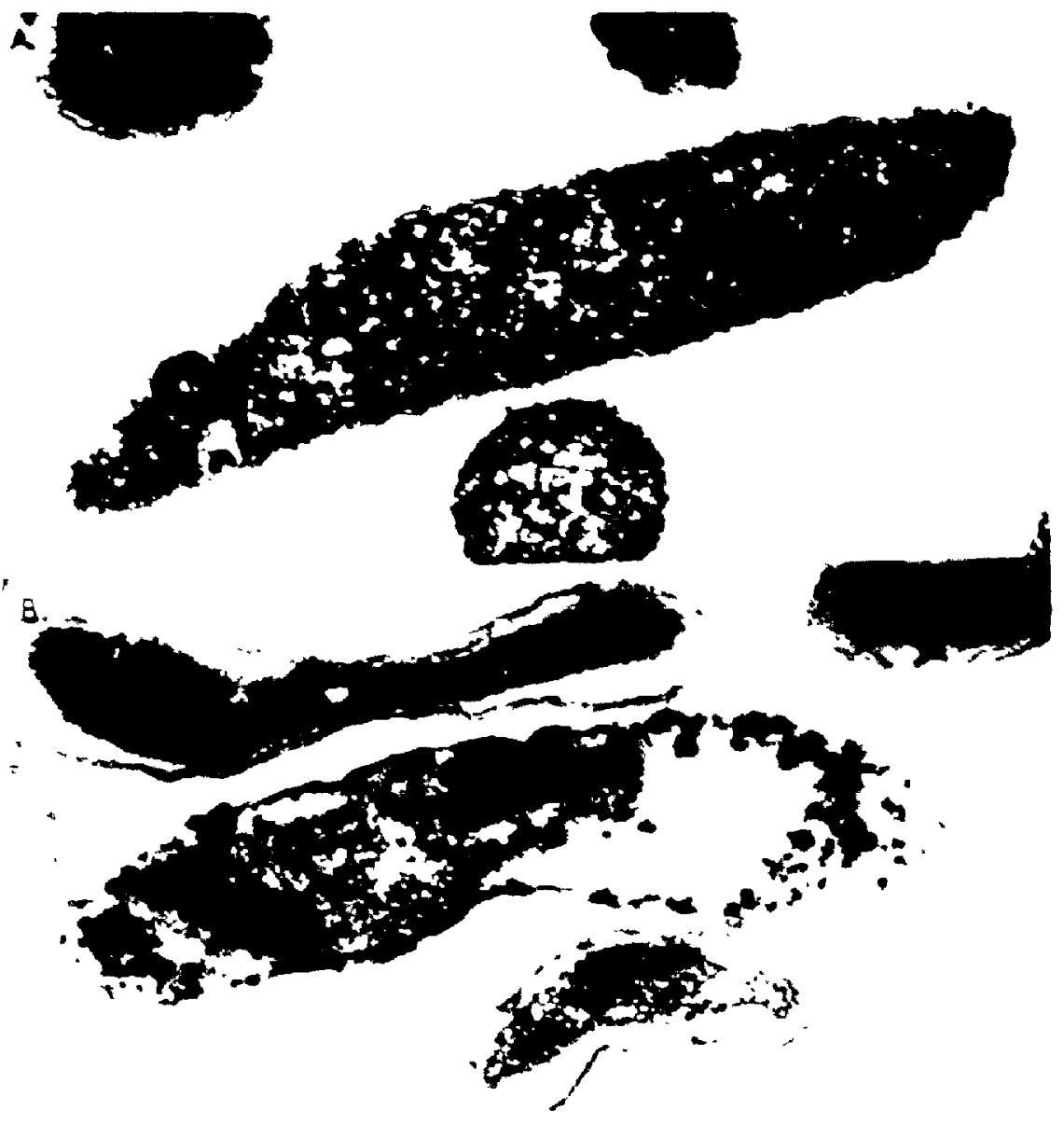



$>$

Figure 36: Non-dissociating-PAGE of purified ATPase (a) stained with Coomassie brilliant blue (arrow shows dye front) and (b) incubated with $5 \mathrm{mM}$ ATP and $10 \mathrm{mM} \mathrm{MgCl} 2$ and' stained for the presence of $P i$ by the method of Abrams, et al.. (1976). 


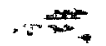
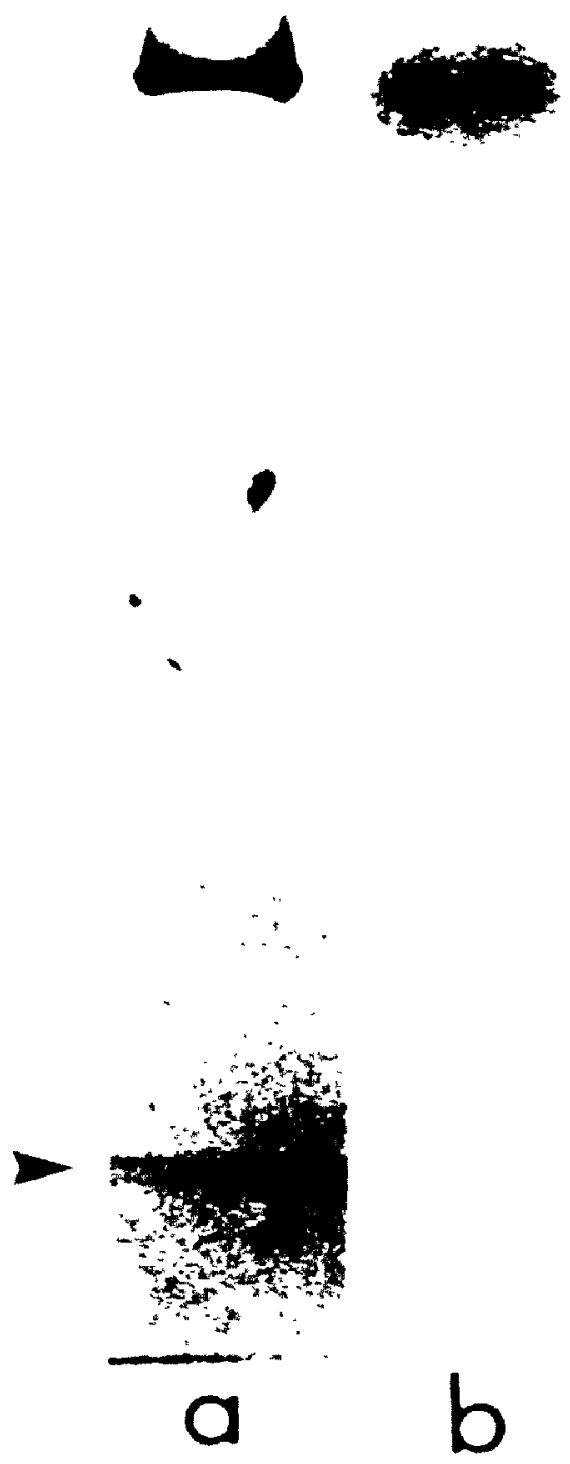



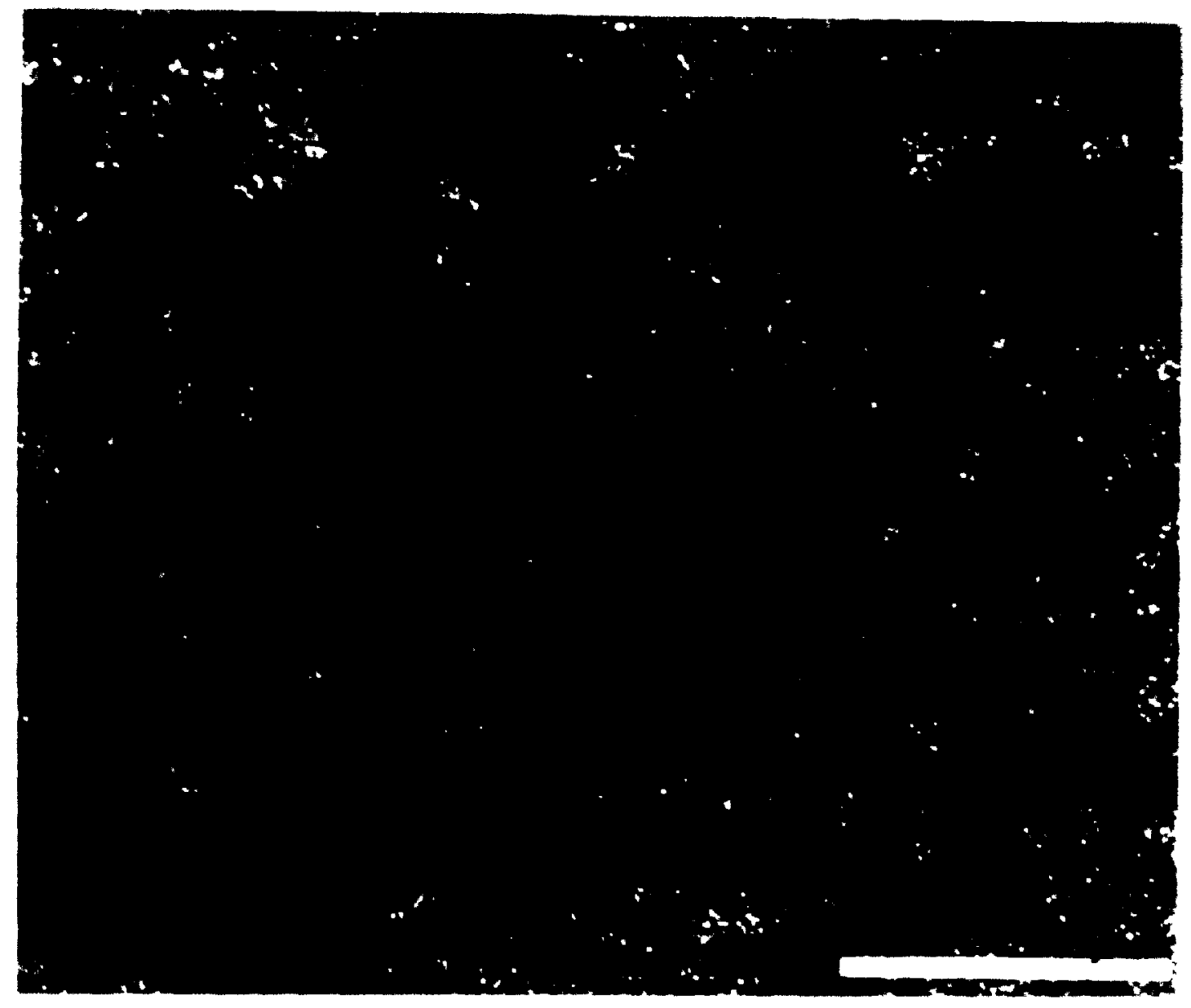


is :

,

'

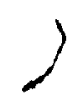

Figure 38: SDS-PAGE of RNA polymerase (lane a) and $C$ jejune ATPase (lane, b). Urea-PिAGE of $C$.

$\therefore$ : Aejpase (lan es). Gels were stained for the presence of protein with coomassie brilliant blue. 
$\therefore k=$

$-k$

$x+k$

a

b

$c$ 

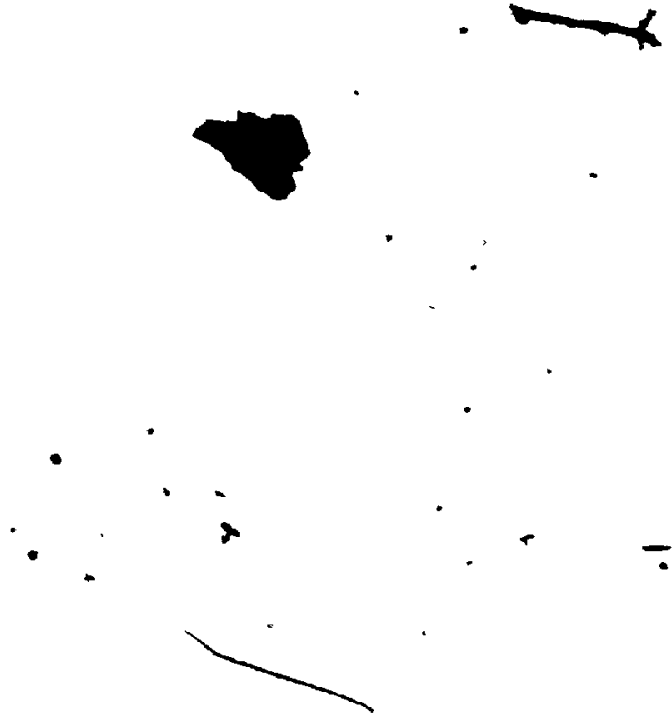

.

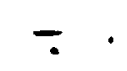

Figure 39: Non-dissociating Page analysis of the refect of cations on $c$. jejuni ATPase activity as revealed by release of Pi from ATP according to . the method of Abramsp et al., (1976). Lane a, stained for protein with Coomassie brilliant

- blue. Lane b. gel slice was incubated with 5 mM ATP and io $\mathrm{mM} \mathrm{MgCl}{ }_{2}$. Lane c, gel slice,was incubated with $5 \mathrm{mM}$ ATP and $10 \mathrm{mM} \mathrm{CaCl} 2^{\circ}$ Lane d, gel silce was incubated with 5 mM ATP alone (no catións).
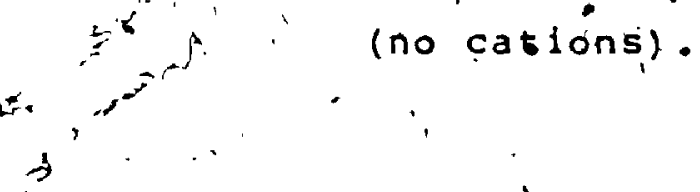

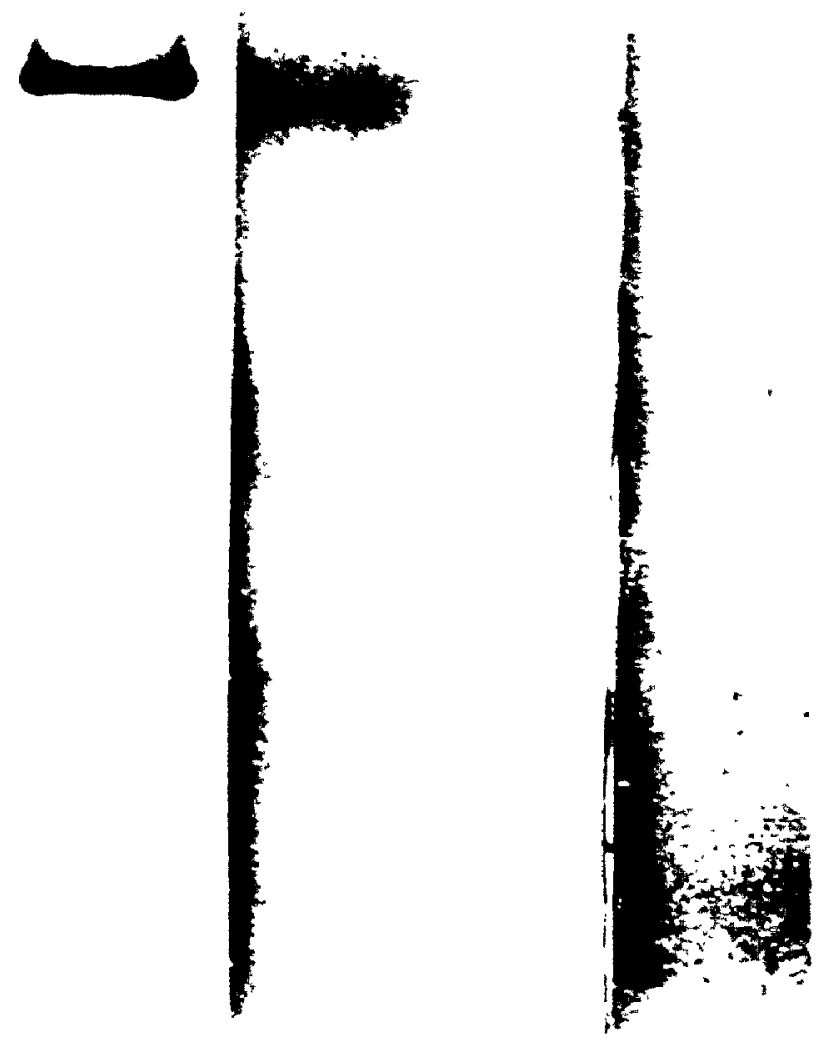

a

b

c

d 



$$
\because
$$




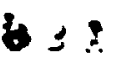

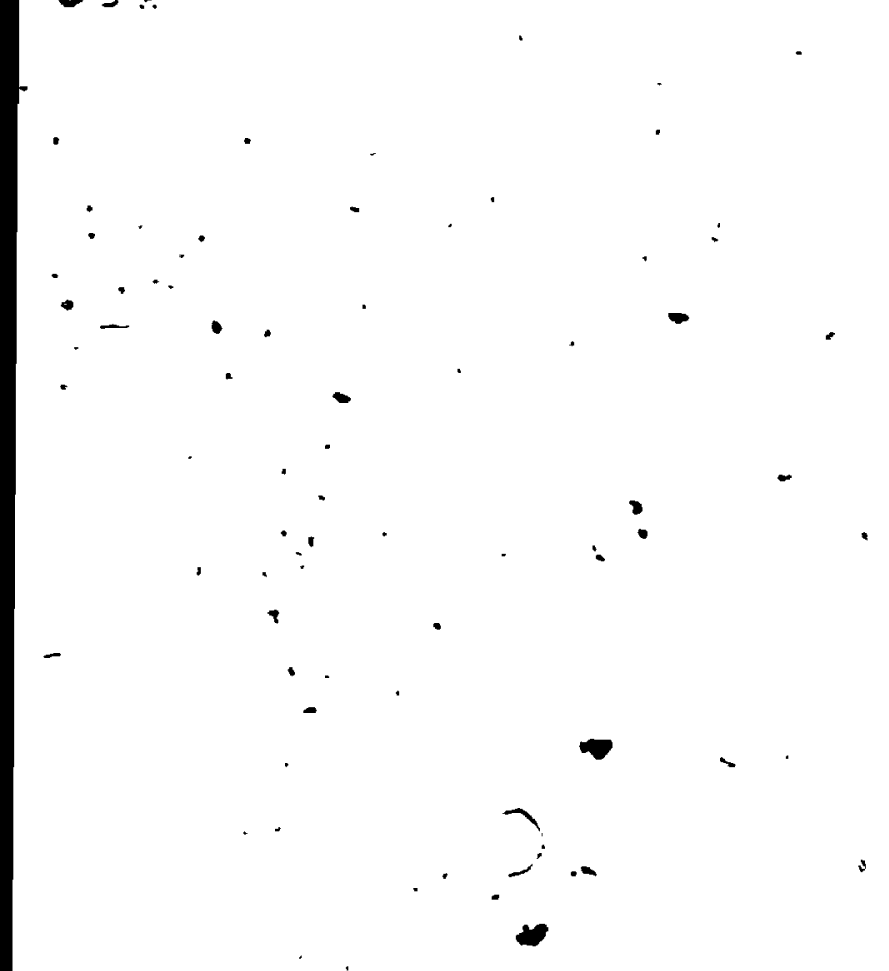


Figure 42: a and $b$, immunocytochemical localization of $\underline{\underline{c}}$. jejuni ATpase on thin'sections of spurr embedded whole cells. Bar $=10 ! \mathrm{nm}$. 


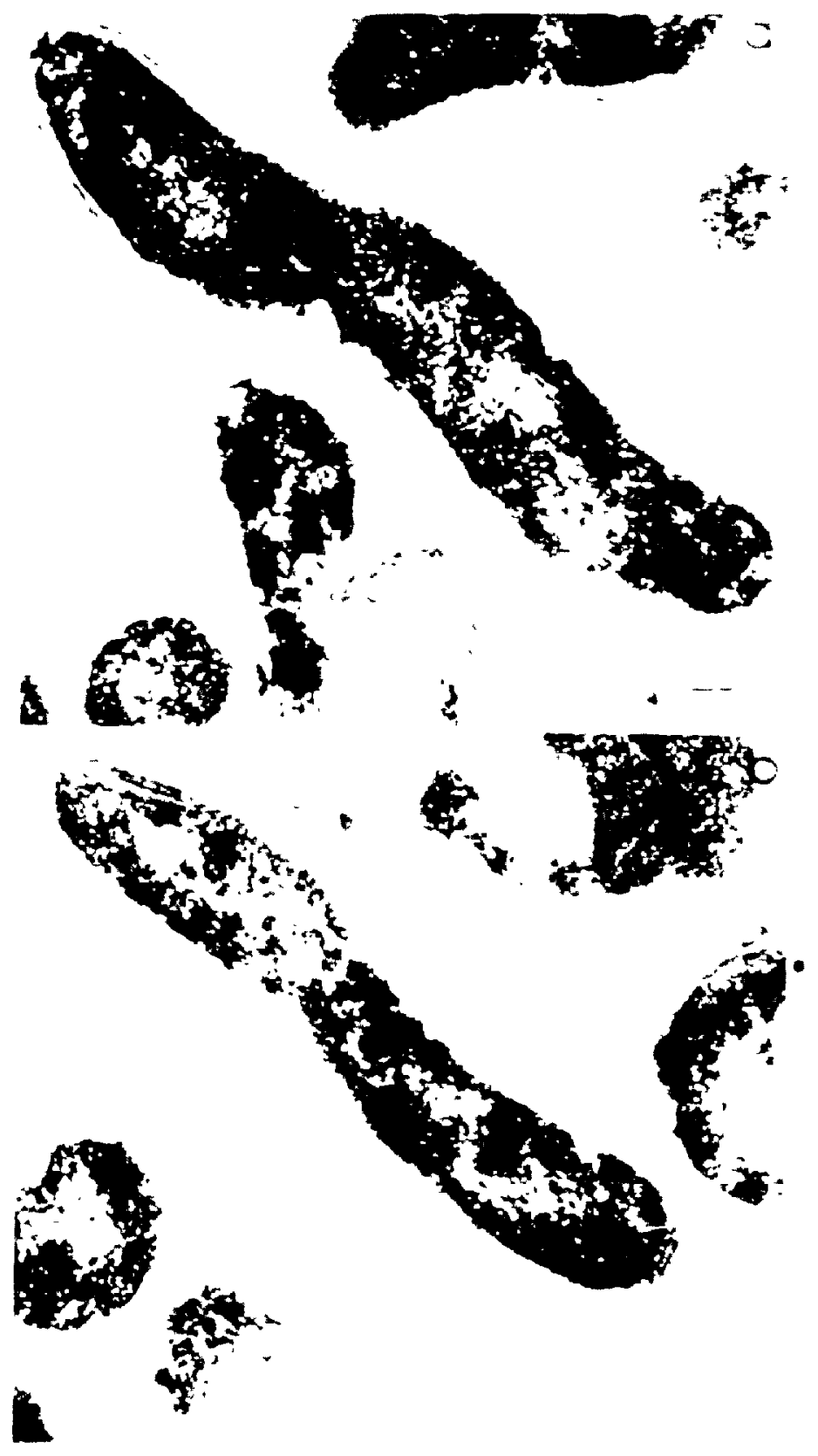


- is

4

Figure 43: a and $b$, immunocytochemical localization of $C$. jejuni ATpase on hydrogen peroxide etched sections of spurt embedded whole cells. Gold. particles $=\cdot 10$ to $15 \mathrm{~nm}$.

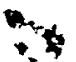

$j$

1

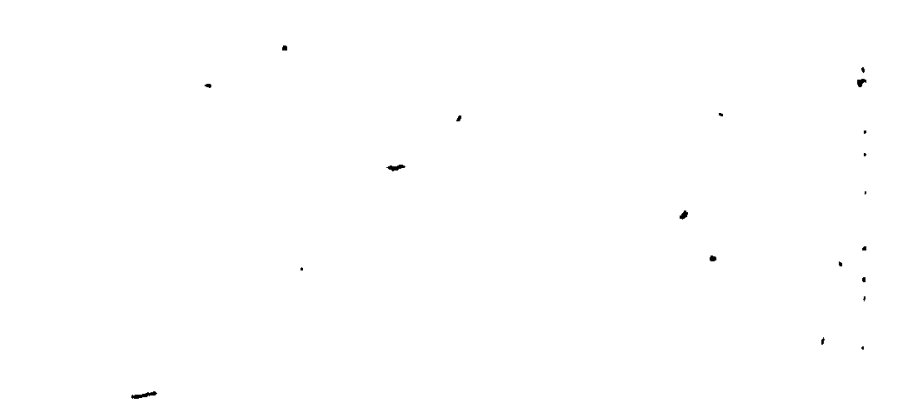




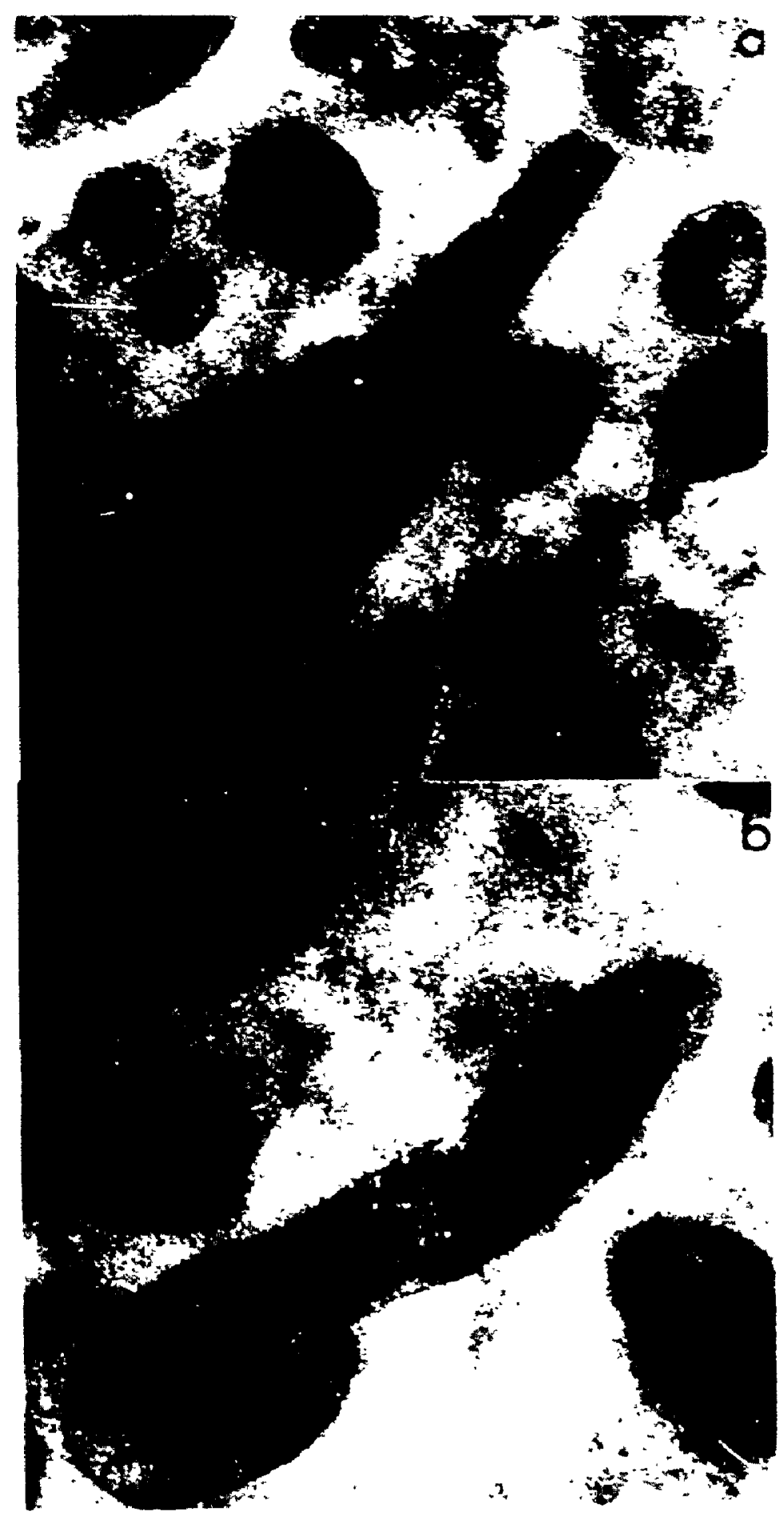


-i

$2=$

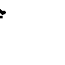

Figure 44: a and b, immunocytochemical localization of $\underline{C}$. jejuni ATPase on thin sections of Lowjcryl KM4 embedded whole cells. Arrows show clusters of gold particles. Gold particles $=5 \mathrm{~nm}$. 


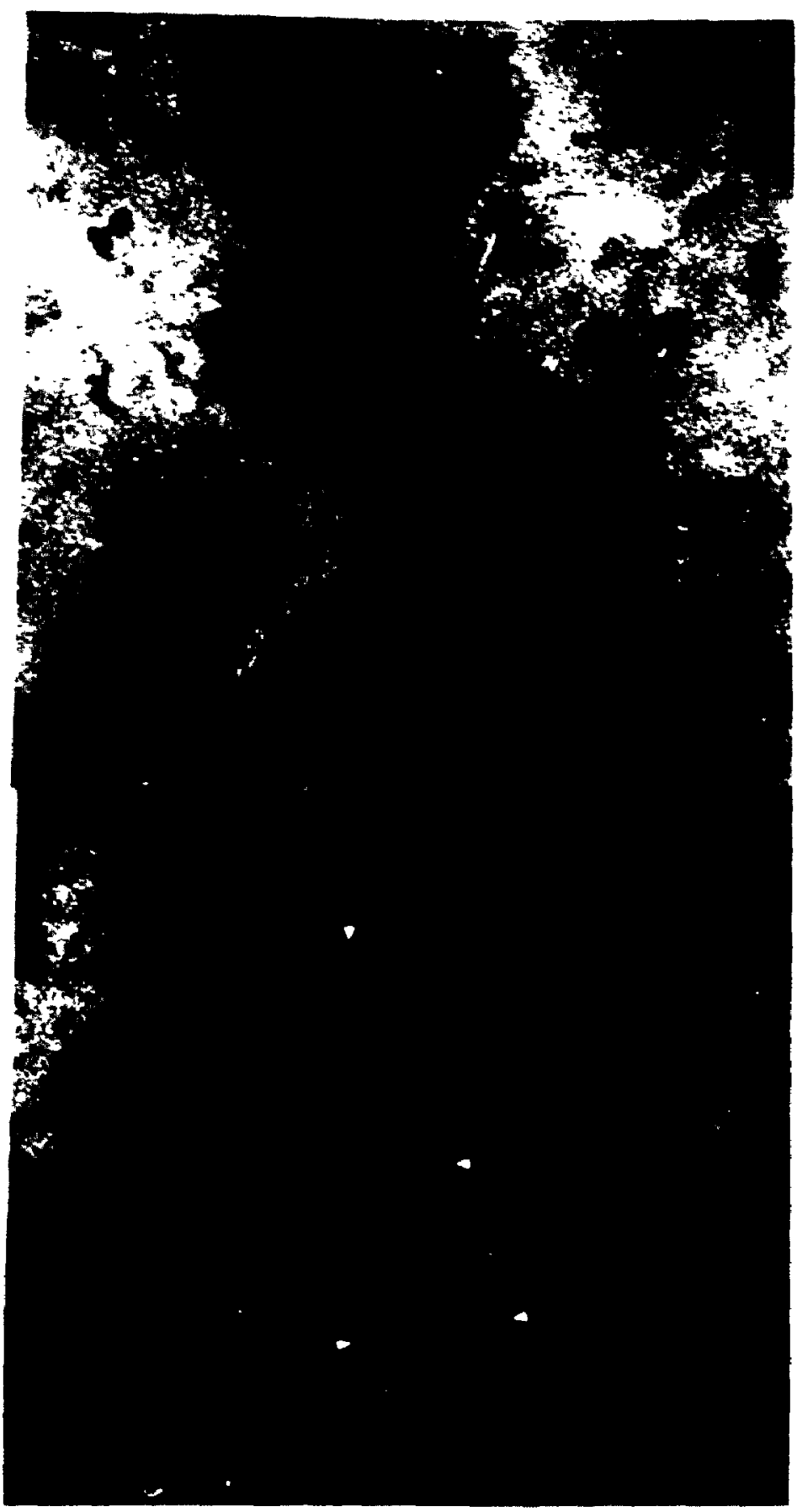


$\therefore$.

Figure 45: Immunocytochemical localization of $\underline{c}$. jejuni Atpase on thin sections of lowicryl kM4 embedded whole cells. Arrow shows large cluster of gold particles at the pole of a cell. Gold particles $=5 \mathrm{rm}$.
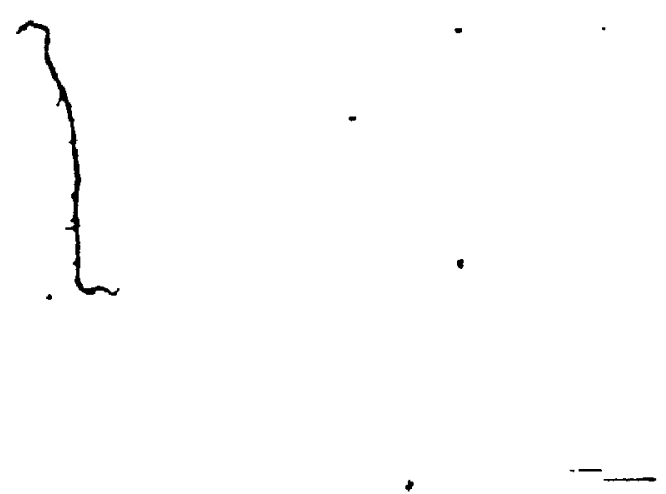


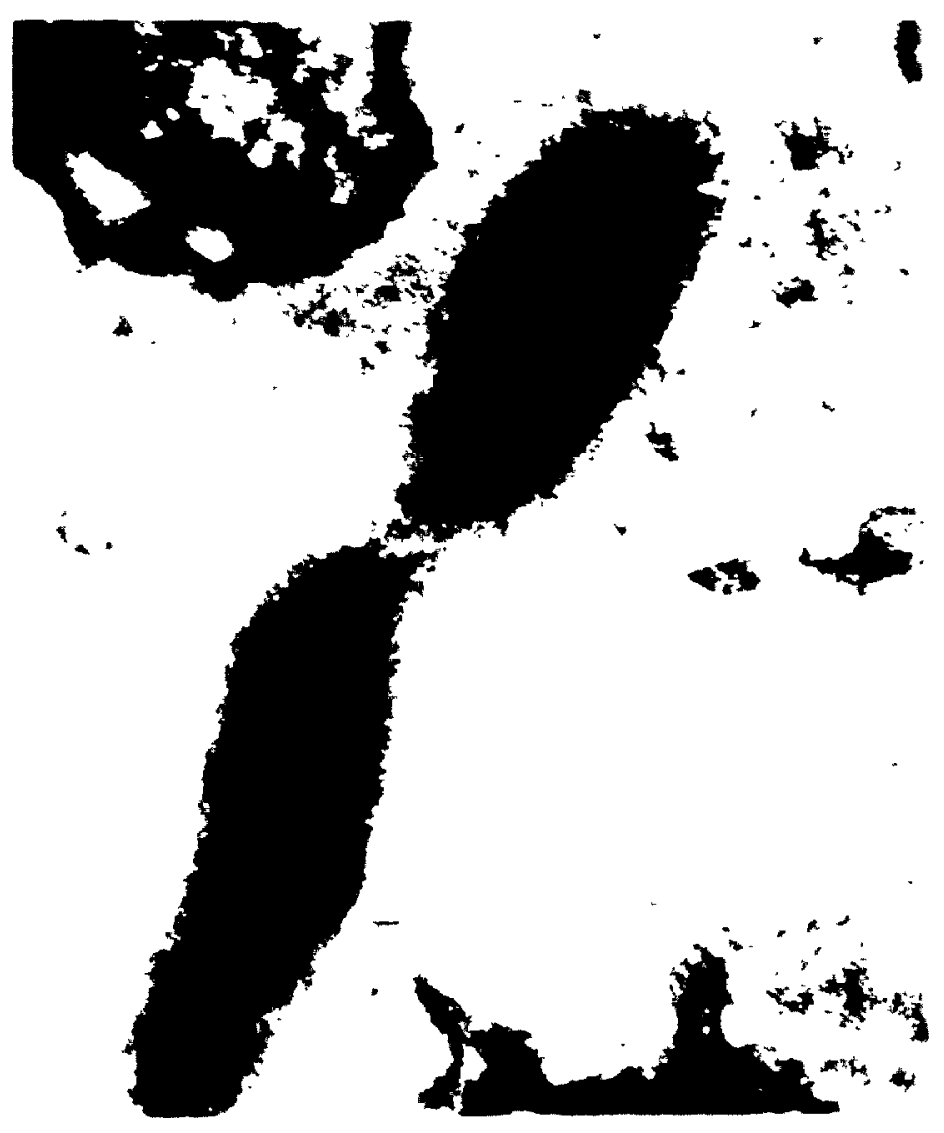



$2 \mathrm{U}^{7}$

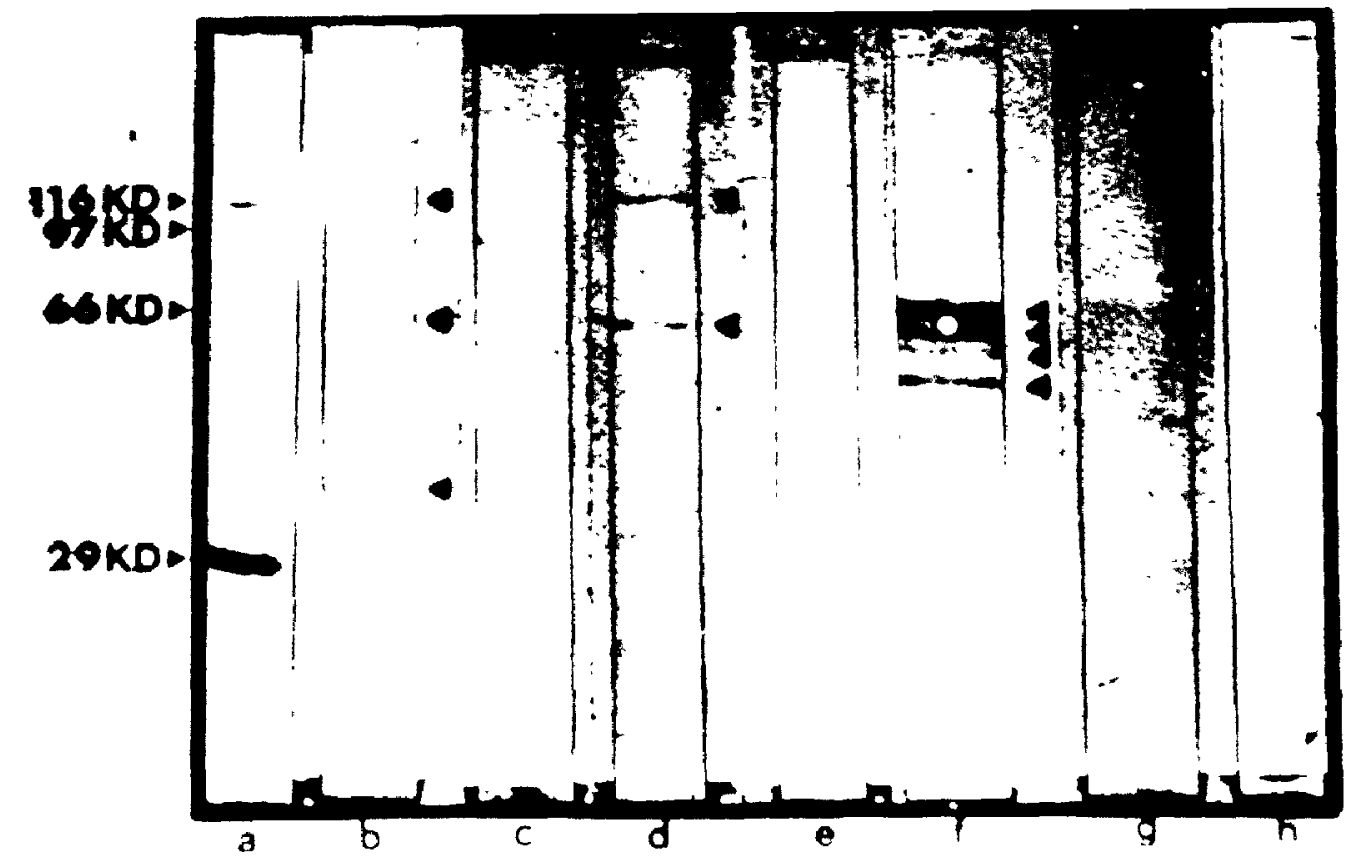


Figure 47: Western blots of whole cell proteins reacted with antibody prepared against the Fl-ATPase Erom E. coli K12. ' Lane a, molecular weight markers. Lane b, $\underline{\varepsilon}$. coll $k 12$, Lane $c, \underline{v}$. - cholera. Lane d, A. serpens MWS. Lane er $\underline{S}$. volutans. Lane $f, \underline{c}$. jejuni. Lane g, M. voltae. Lane $h$, rat liver mitochondria. Arrows in lanes $b, c, d, e$, and $h$, mark protein species which bound antibodies.

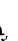




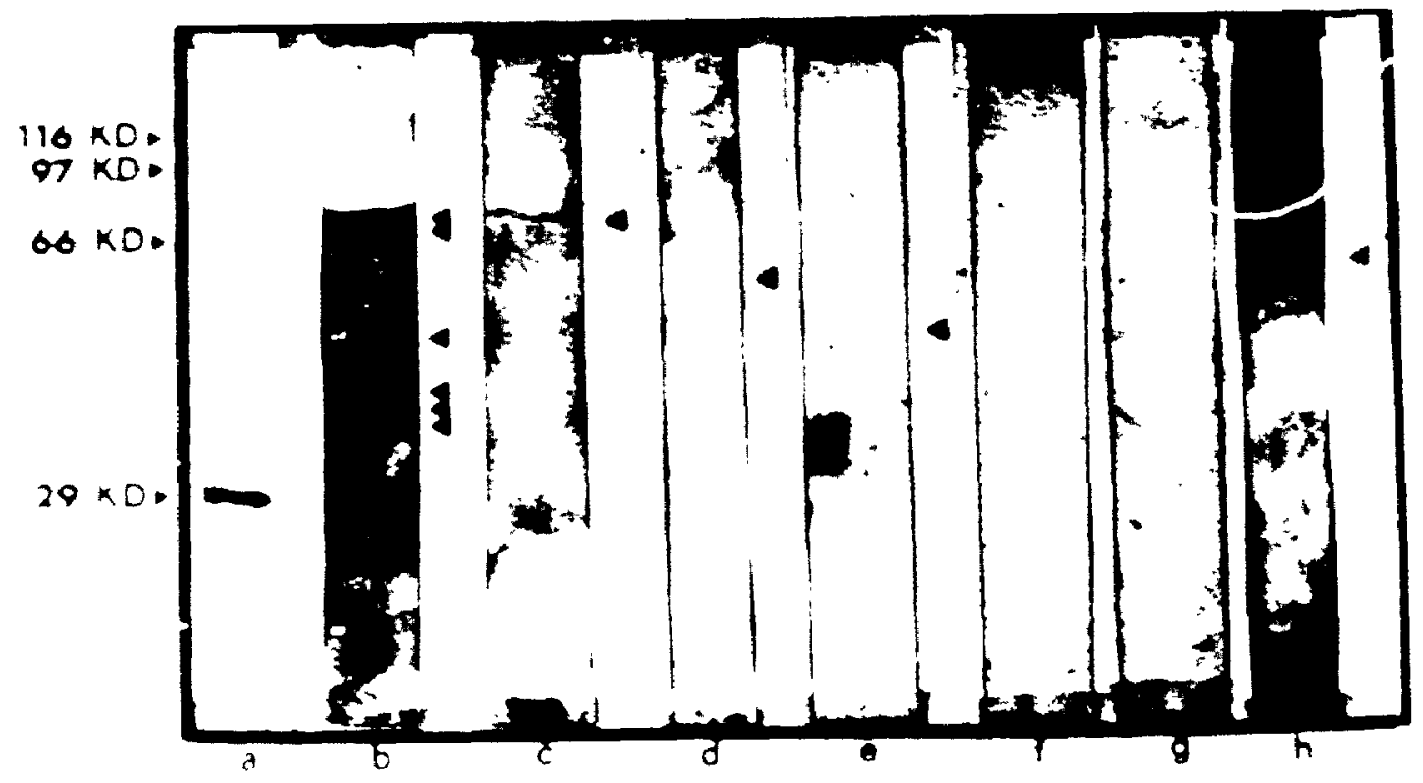




\section{References}

Abram, D. 196,5. Electrom microscope observation on Intact cells, protoplasts, and cytoplesmic membrane of Bacillus stearothermophilus. J. Bacteriol. 89: 855-873:

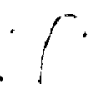

Abrams, A. 1965. The release of bound adenosine triphosphatase from isolated bacterial membranes and tho properties of the solubilised enzyme. J. Biol. Chem. 340 : $3675-3681$

Abrams, A. 1976. Bacterial ATPases. In The Enzymes of Biological Membranes (Martosi, A., ed.), vol 3, pp. 57-73. Plenum Press, N.Y.

Abrams, A., and Baron, C. 1970. Inhibitory action of carbodicimides on bactẹrial membrane ATPase. Biochem. Biophys. Res. Commun. 41: 858-863..

Abrams. A. and Smith, J.B. 1974. Bacterlal Membrane ATPase. in The Enzymes (Boyer, P.D.. ed.), vol. 10, pp. 395-429. Academic Press, N.Y.

Torams, A., McNamara, ,P., and Johnson, F.B. 1960. Adenosine triphosphatase. in isolated bacterial celi membranes. J. Biol Chem. 235: 3659 . 


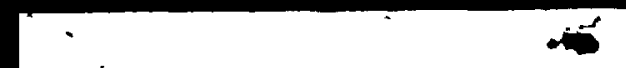

Abrams, A.' Smith, J.B., and Baron, C. 1972.

Larbodismide-resistant membrals adenosine triphosphatase in mutants of Streptococcus faecalis. I. Studies on the mechanism of resistance. J. Biol. Chem 247; 1484-1488.

Abrams, A., Morris, D., and Jensen, C. 1976. Chymotryptic cpnversion of bacterial membrane ATPase to an active form with modified alpha chains and defective membrane binding properties. Biochem. 15: 5560-5565.

Ackrell, B.A.C., and Jones, C.W. 1971. The respiratory system of Azetobacter vinelandii. I. Properties of phosphorylating respiratory membranes. Eur. J. Biochem. $20: 22-28$

Addison. R., and Scarborough, G.A. 1981. Solubilization and purification of the Neurespera plasma membrane $H^{+-}$ ATPase. J. Biol. Chem. 256: 13165-13171.

Adler, H.I., Fisher, W. D., Cohen. A., and Hardigee, A.A. 1967. Miniature Escherichia coli cells deficient in DNA. Proc. Natl. Acad. Sci. U.S.A. 57: 321-326.

Adolfsen. R., McClung, J.A., and Moudrianakis, E.N. 1975.

Electrophoretic microheterogeneity and subunit composition of the iss coupling factors of oxidative photosynthetic phosphorylation. Biochem. 14: 1727-1735. 
Adolfsen, R., and Moudrianakis, E.N. 1971. Purification and properties of two soluble coupling tactors of oxidative phosphorylation from Alcalizènes faecalis. Biochem. 10: 2247-2253.

Adolfsen, R., and Moudrianakis, E.N. 1976: Molecular polymorphism and mechanisms of activation and deactivation of the nydrolytic functions of the coupling factor of oxidative phosphorylation. Biochem. 15:4163-4170.

Amzel. L.M. , and Pedersen, P.L. 1983. Proton ATPases: Strućture and mechanism. Annu. Rev. Biochem. 52: 801-824

Andreu, J.M., Albendea, J.A., and Munoz, E. 1973. Membrane adenosine triphosphatase of Microceccus lysedeikticus; molecular properties of the purified enzyme unstimulated by trypsin. Eur. J. Biochem. 37: 505-515.

Andreu, J.M., and Munoz, E. 1975. Micrececcus

Lysodeikticus ATPase; purification by preparative gel electrophoresis and subunit structure studied by urea and sodium dodecyl-sulphate gel electrophoresis. Biochim. Blophys. Acta 387: 228-233. 
Archer, D. B., Rodwell, A.W., and Rodwel1, E.S. 1978. The nature and location of Acheleplasma lajdlami membrane proteins investigated by two-dimensional gei electrophoresis. Biochim. Biophys. Acta 513: 268-283.

Asano, A., Cohen, N.S., Baker, R.F., and Brodie, A.F 1973. Orientation of the cell membrane in ghosts and electron transport particles of Mrcobacterium phlei. J Biol. Chem. 248: 3386-3397.

Azocar, U., and Munoz, E. 1977 Extrinsic and intrinsic factors that influence inactivation and purification of the unstable adenosine triphosphatase solubilized from membranes of an escherichil coli K12 strain. . Biochim. Biophys. Acta 482: 438-45e.

Baccarini-Melandri, A.. Gest, H. and San Pretro, A. 1970. A coupling ractor in bacterial photohosphorylation. J. . Biol. Chem. 245: 1224-1226.

Baird. B.A., Hammes, G.G. 1979. Stracture of oxidativeand photo-phosphorylation coupling factor complexes. Biochim. Biophys. Acta 549: 31-54.

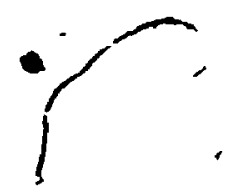


Bayer, M.E. 1968. Areas of adhesion between wall and membrane of Escherichia cell. 'J. Gen: Microbiol. 53: $395-404$.

Balch.'H.E., and Wolie, R.S. 1979. Specificity and biological distribution of Co enzyme $M$ (2-mercaptoethanesulfonic acid). j. Bacteriol. 37 : $256-263$

Bell. R.M. Mavis, R. $\dot{D}$., Usborn, M.J., and Vagelos. F.R. 1971. Enzymeś of phosphoilipid metabolism: Localization in the cytoplasmic and outer membrane of the cell envelope of Escherichia'soli and Salmonella typhimurium. 'Biochim. Biophys: Acta 249: 628-635.

Bengis-Garber; C. , and Gromet-Elhanan, Z. 1979. Purification of the energy-transducing adenosine triphosphatase complex from Rhedesplridlum rubrum. Biochem. i8: $3577-3581$.

Bennum. A., and Racker. E. 1969. Partial resolution of the. enzymes catalyzins photophosphorylation. IV. Interaction. of coupling factor 1 from chloroplasts with components of the cholorplast membrane. 'J. Biol. Chem. 244: 1325-1331. 
Berg, H.C. 1974. Dynamic properties of bacterial flagellar motors. Nature (London) 249: 77-79

Berg, H.C. 1975. Bacterial behaviour. Nature (London) 254: $389-392$

Beveridge, T.J. 1981. Ultrastructure, chemistry, and function of the bacterial wall. Int. Rev. Cytol. 12. $229-317$.

Beverfify T.J. and Davies. J.A. 1983. Cellular responses of Bacilus subtilis and escherichia celi to the liram stain. J. Bacteriol. 156: '846-858.

Biketov, S.F., Kasho, V.N., Kozlor, I.A., Mileykoiskaya, Y.I., Ostrovsky, D.N., Skulachev, V.P., ETikhonova, G.V.. 'and Tsuprun, V.L. 1982. Fi-like ATPase form anaerobic bacterium Lactobacillus cased contains six similar subunits. Eur. J. Biochem. 129: 241-250.

Birch-Andersen, A., Maaloe, O., and Sjostrand. 1953. High resolution electron micrographs of sections of Escherichia celi. Biochim. Biophys. Acta 12:395-400. 
Bogin, E., Higashi, T., and Brodie, A.F. 1970. Oxidative phosphorylation in fractionated bacterlal systems XLIII. Coupling factors associated with the NAD+-linked electron transport pathway. Arch. Biochem. Biophys. 136: 337-351.

Bowman. E.J. 1983. Comparison of the vacuolar membrane ATPase of Neurespora crassa with the mitochondrial and plasma membrane ATPase. J Biol. Chem. 258: 15238-15244

Bowman. E.J.. Bowman. B.J., and Slayman. '.$W .1381$.

Isolation and characterization of plasma membranes from wlld type Neurespora crassa. J. Biol. Chem. 256: $12.336-12342$.

Bowman, B.J., Mainzer, S.E., Allen, K.E. and Slayman. C.W. 1978. Effects of inhibitors on the plasma membrane and mitochondrial a; denosine triphosphatase of Neucospora crassa. Biochim. Biophys. Acta 512: 13-28.

Bragg, P.D., Davies, P.L.; and Hou, C. 1973. Effect of removal or modification of subunit polypeptides on the coupling factor and hydrolytic activitzes of the $\mathrm{Ca}^{2+}$. and $\mathrm{Mg}^{2}$ +-activated adenos Jhe triphosphatase of Escherichia celi. Arch. Biochem Biophys. 159: 664-670. 
Bragg, P.D. - and Hou, C. 1972. Organzation of proteins in, the native, and reformed outer membrane of Escherichia * seli. Brochim. Biophys. Acta 274: 478-488

Brage. P.D., and iou. 5 1975. Subunit composition function and spacial arrangement in the $\mathrm{Ca}^{2+-}$ and $\mathrm{Mg}^{2}+$-activated adenosine triphosphatases of Escherdchia

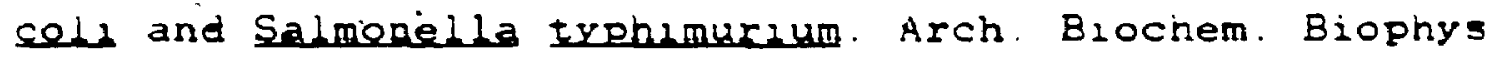
167: $311-321$.

- Braun. V., and Rehn, K. 1969. Chemical characterization, spatial distribution, and function of a lipoprotern fmurein-lipoprtoein) of Escherichia coli cell wall: The spoasic effect of trypsin on the membrane structure. Eur. J. Biochem. 10: 426-438.

Braun, V., and Sieglin, U. 1970. The covalent murein-1ipoprotein structure of the Escherichia seli cell wall. The attachment site of the lipoprotein on the murein. Eur. J. Biochem. 13: 336-346.

Braun, V.. and Wolff, H. 1970. The murein-lipoprotein linkage, in the cell wall of Escherichis cell. Eur. J.. Biochem. 14:.387-.391. 
Bronk, J.R., and Lesse. H.J. 1974. Accunulation of amino-acids and glucose by the mammaitan small intestine Symp. Soc. exp. Biol. 28: 283-304.

Burdett. I.D., and Murray, R.G.E. 1974. Septum formation in Escherichla coli: "Characterization of septal structure and the ${ }^{-}$effects of antibiotics on cell division $J$ Bacteriol. 119:-303-324.

Carrerra. J.. 'Andreu.' J.M. and $\$$ Munoz. E. 1973 - Difierential sensitivity to trypsin digestion af purified

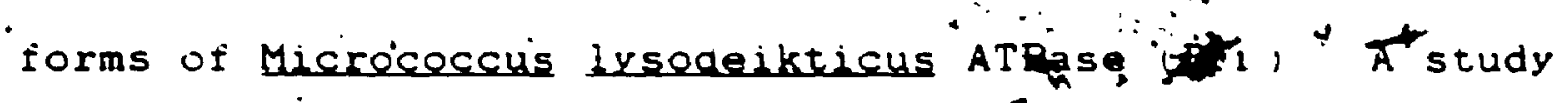
of their structural and conformational difierence's and mechanism of conversion. Biochim. Biophys. Acta 492: $387-398$.

Carresra, J.. Munoz, E. Andreu, J.M. and Nieto. M. 1976. Mtcrececalle Lysodeikticus membrane ATPase: Effect of trypsin on stimulation of a purified form of the enzyme and identification of its natural inhibitor Biochim. Biophys. Acta 436: 183-189.

Catteral, W.A., and Pedersen, P.L. 1971. ATPase form rat liver mitochondria. I. Purification, homogeneity, and physical propefties. J. biol. Chem. 246: 4987-4994. 
Chalcroft, J.P., Bullivant, S., and Howard, B.H. 1973. Ultrastructural studies on Selenomenas ruminantium form sheep rumen. J. Gen. Microbiol. 19: 135-146.

Chapman. G.B., and Hillier, J. 1953. Electron microscopy of ultra-thin sections of bacteria. I. Cellular division in Bachlus sereus. J. Bacter101. 66: 362-373.

Sheng. K. -J.. and Costerton. J.W. 1977. Alkaline phosphatase activity of rumen bacteria. Appl. Environ. Microbiol. 34: 586-590.

Chung, Y-S., and Salton, M.R.J. 1980. Inhibition of Micrececcus lysedeikticus membrane-bound and purified F1-ATPase by N-ethozycarbonyl-2-ethozy-1. 2-dihydroquinoline. FEMS Letters 8: 183-186.

Clarke. D.J., and, Morris. J.G 1976. Partial purification of a dicyclohexylcarbadimide-sensiti ye membrane adenosine triphosphatase complex from the oblieately anaerobic bacterium clestridium pasteurianum. Biochem. J. 154 : 725-729.

Cohen-Bazire, B., and Kunisawa, R. 1963. The fine structure of Bhodespixillum rubrum. J. Cell Biol. 16: $401=419$. 
Costerton. J.W., Ingram, J.M., and Cheng, K.J. 1974.

Strucutre and function of the cell envelope of

Gram-negative bacteria. Bacteriol. Rer. 38: 87-110.

Costerton. J.W., Murray, R.G.E., and Robinow. C.F 1961.

Observations on the motility and structure or

Vitreoscilla. Can. I. Microbiol. I: $329-339$

Loulton, J.W., and Murray, R.G.E. 1977.

Membrane-associated components of the bacteriai ilagellar apparatus. Biochim. Biophys. Acta 465: 290-310.

Coulton, J. W., and Murray, R,G.E. 1978. Cell envelope association in Aquaspirillum serpens flagella. J.

Bacteriol. 136: 1037-1049.

Lox, G.B:, Downie, J.A., Fayle, D.R.H., Gibson, F.. and Radik. J. 1978. Inhibition, by a protease inhlbitor of the solubilization of the Fl-portion of the Mge+-stimulated adenosine triphosphatase of Escherichia celi. J

Bacteriol. 133: 287-292.

Curtis. N.A.C., Richmond, M.H., and Sykes, R.B. 1972. "Periplasmic" location of a beta-lactamase specified either by a plasmid or a chromosomal gene in Escherichto cel1. J. Bacteriol. 112: 1433-1434. 
Datta, D.B., Arden, B., and Henning, U. 1977. Major proteins of the Escherichia celi outer cell envelope membrane as bacteriophage recoptors. J. Bacteriol. 131: $821-829$.

Davies, P.L., and Brage, P.D. 1972. Properties of a soluble $\mathrm{Ca}^{2+-}$ and $\mathrm{Mg}^{2+-a c t i v a t e d ~ A T P a s e}$ released from Escherichza seli membranes. Biochim. Biophys. Acta 266 : $27 \dot{3}-284$.

Deguchi,. N., Jorgensen. P. L. . and Maunsbach. A.B. 1977. Uilfastructure, of the sodium pump. Comparison of thin sectioning, nggative staining and freeze-fracture of purified, membrane-bound $\left(\mathrm{Na}^{+}, \mathrm{K}^{+}\right)$-ATPase. J. Cell Biol. 75: $619-634$.

Delhez, J., Dufour, J.P., Thines, D., and Gotfeau, A. 1977. Comparison of the properties of plasma membrane-bound ATPase in the yeast Schizesaccharomyces pombe. Eur. J. Biochem. 79: 319-328.

De Meis, L. and Vianina, A. 1979. Enendy interconversion by the Ca2t-dependent ATPghe of sarcoplasmic reticuldm. Añnu. Rev. Blochem. 48: 275-292. 
De Pamphilis, M.L., and Adler, J. 1971. Purification of intact flagella from Escherichia seli and Bacillus subtilis. J. Bacteriol. 105: 376-383.

De Petris, S. 1965. Ultrastructure of the cell wall of Escherichia coli. J. Ultrastruct. Res. 12: 247-262.

De Petris, S. 1967. Ultrastructure of the cell wall of Escherichia. seli and chemical nature of it constituent layers. J. Ultrastruct. Res. 19: 45-83.

$\therefore$

Dimmitt, $K$. , and Simon, M. 1971. Purification and thermal - stability of intact Bacillus subtilis flagella.'J: Bacteriol. 105 : 369-375. s

Di Rienzo, J.M., Nakamurä, K., and Inouye, M. 1978. The outer membrane proteins of Gram-ñegative bacteria: Biosynthesis, assembly and functions. Annu. Rev. Biochem. 47: $481-532$.

Dootsch, R.N., and. Sjoblad, R.D. 1980. Flagellar structure and function in eubacteria. Annu. Rov. Mtcrobtol. 34 : 69-108. $\because$

Downie, J.A., Gibsoms F., and Cox, G.B. 1979. Membrane ATPases of prokaryotic cekls. Annu. Rev. Biochem. 48: $103-131$. 
Dufour, J.P., and Goffeau, A. 1978. Solubilization by lysolecithin and purification of the plasma membrane ATPase of the yeast sehizosaccharomyces pombe. J. Biol. Chem. 253: $7026-7032$.

Dunn, S.D., Tozer, R.G., Antczak. D.F., and Heppel, L.A. 1985. Monoclonal antibodies to Escherichia celi Fl-ATPase. Correlation of binding site location with interspecies cross reactivity and effects on enzyme activity. J. Biol. Chem. 260: 10418-10425.

Dux, L.. and Martonosi: A. 1983a. Two dimensional arrays of proteins in sarcoplasmic reticulum and purified $\mathrm{Ca}^{2+-A T P a s e}$ vesicles treated with vanadate. J. Biol. Chem. 258: $2599-2603$.

Dux, L. . and Martonosi. A. 1983b. 'Caz+-ATPase membrane crystals in sarcoplasmic riticulum. J. Biol. Chom. 258: $10111-10115$.

Ellar, D.J., Munoz, E., and Salton, M.R.J. 1971. The effoct of low concentrations ol glutaraldehyde on Microcecaus lysedeikticus membranes: Changes in the release of membrane-associated enzymes and membrane structure. Biochim. Biophys. Acta 225 : 140-150. 
Epstein, F. 1069. The role of sodium and potassium ATPase in renal sodium readsorption. In Renal transpert and diureties (Thurau, K., and Jahrmayker. H., eds.). PP. 67-76. Springer, N.Y.

Epstein, W., Whitelaw, V., and Hesse. J. 1978. A K+. transport ATPase in Escherichia celi. J. Biol. Chom. 253 : $6666-6668$.

Ernster. L.. Carlsson. L., Hundal, T. . and Norbenbrand, K. 1979. Mitochondrial ATPase Inhibitor: Properties and Applications. Methods in Enzymol. 55: 399-407.

Essmann, M., Christiansen, C., Karlsson, K.A., Hansson. G.C., and Skou, J.C: 1980. Hydrodynamic properties of solubilizẹd ( $\mathrm{Na}^{+}+\mathrm{K}^{+}$)-ATPàs from rectal glands of squalus acarthias. Biochim. Biophys. Acta 603: 1-12.

Evans, M.C.W. 1969. Progress in Photosynthetic Research. V́ol. III., (Metzner, H., ed.), pp. 1474-1475. Tubingin. International Biol: Union.

Ferris, F.G., and Beveridge., T.J. 1983. Structure and coll envelope associations of flagellar basal complexes of Vibrive cholerae and Campylebacter fetus. Can. 'J. Microbiol. 30: 322-333: 
Forbush, B., Kaplan, J.H., and Hofiman, J.F. 1978. characterization of a new photoaffinity derivative of ouabain: Labeling of the large polypeptide and a proteolipid component of the Na. K-ATPase. Biochem. 17: $3667-3676$.

Forgac, M.D., Eantely, L., Weidenna, B., Alstiel, L., and Branton. D. 1978. Clathrin-coated vesicles an ATP-dependent prgton pump. Proc. Natl. Acad. Sci. U.S.A. $80: 1300-1303$.

Foster. D.L.. and Eillingame, K.H. 1978. Purification of a dicyclohexylcarbodiimide sensitive, energy transducing aderosine triphosphatase complex from Escherichia celi. Fed. Proc. 37: 1520, abst. 1379.

. Foster, D.L., and fillingame, R.H. 1979.

Energy-transducing ht-ATPase of Escherichia eoli:

Purification, reconstitution and subunit composition. J. Biol. Chem. 254: 8230-8236.

Funahara, Y., and Nikaido, H. 1980. Asymmetric localization of lipopolysaccharides on the outer membrane of Salmenella typhimurium. J. Bacteriol. 141: 1463-1465. 
Futai, M., and. Kanazawa, H. 1980. Role of subunits in proton translocating ATPase (FoFi). Curr. Topics Bioenerg. 10: 181-215.

Futai, M., and Kanazawa, H. 1983. Structure and function of proton-translocating adenosine triphosphatase (FoFl):

- Biochemical and molecular biological approaches.

Microbiol. Rev. 47: 285-312.

Futal, M. Sternweis, P.C., and Heppel, L.A. 1974.

Purification and properties of reconstitutively active and inactive ATPase from Escherichia coli. Proc. Nath. Acad. Sci. U.S.A. 71: 2725-2729.

Gallagher, S.R., and Leonard, R.T. 1982. Effect oi vanadate. molybdate and azide on membrane associated ATPase and soluble phosphatase activities of corn roots. Plant Physiol. ㅁ: 1335-1340.

Galloway, C.J., Dean, G.E.. Marsh. M., Rudnick. 8.. and Mellman, I. 1983. Acidification of macrophage and fibroblast endocytic vesicles in vitre. Proc. Natl. Acad. Sci. U.S.A. 80: $3334-3338$.

Gapber: M.P., and Steponkus, P.L. 1974. Identification of chloroplast coupling factor by freeze-eching and negative staining techniques. J. Cell Biol. 63: 24-34. 
Gay, N.J., and Walker, J.E. . 1981. The atp operon: nucleotide sequence of the region encoding the alpha subunzt of Eschertchia seli ATP-synthase. Nucleic Acids Res. श: 2187-2194.

Ghuysen. J.M. 1968. Use of bacteriolytic enzymes in determination of cell wall structure and their role in cell metabolism. Bacterigl Rev. 32: 425-464.

Glauert. A.M. . and Thornley, M.J. 1969. The topography ot the bacterial cell wall. Annu: Rev. Microbiol. $\angle 3$ : $159-198$.

Glickman, J., Croen, K., Keliy, S., and Al-Awqati, Q. 1983. Golgi membranes contain an electrogenic $H^{+}$pump in parallel to a chloride conductance. J. Cell. Biol. 97: $1303-1308$.

Glynn. I.M. 1957. The action of cardiac glycosides on sodium and potassium movement in human red cells. $J$. Physiol. (London) 136:148-173.

Goffeau. A., and Slayman, CiW. 1982: The protontranslocating ATPase of the fungal plasma membrane. is Biochim. Biophys. Acta 639: 197-223. 
Gram. C. 1884. Uber die'isolirte Farbung der Schizomyceten in Schnitt-und Trockenpraparaten. Fortschr. Mod. 2: $185-189$

Hachimori, A., Maramatsu, N., and Nosch, Y. 1970. Studies on an ATPase of thermophilic bacteria l. Purification and properties. Biochim. Biophsy. Acta. 206: 426-437'.

Haddock, B.A., and Jones, C.W. 1977. Bacterlal Respiration. Bacteriol. Rev. 41:"47-99.

Hansen, F.G., Niglson, J., Riise, Ee., and von Meyenburg, K. 1981. The genes for the eight subunits of the membrane bound ATP synthase of Escherichia seli. Mol. Gén. Genet. 183: $463-472$.

Hanson. R.L., and Kennedy, E.P. 1973. Energy-transducing adenosine triphosphatase from Escherichia celi: purification, properties and inhibition by antibody.' J. Bacteriol. 114: $772-781$.

Hare,.J.E. 1975. Purification and characterization of an . ATPase complex from membranes of Escherichia celt, which is sensitive to DCCD. Biochem. Biophys. Res. Commun. 66: 1329-i337. 
Harold. F.M. 1972. Conservation and transtormation of energy by bacterlal membranes. Bacteriol. REv. 36: $172-830$

Harold. F.M. Baarda, J.R.. Baron. C. . and Abrams. A. 1869. Inhibition of membrane-bound adenosine triphosphatase and cation transport in Streptoceccus Laecalis by N,N'-dicylohexyl-carbodiimide. J. Biol. Chem 244: $2261-2268$.

Hadselbach. W.. and Suko, J. 1974. Calcium and phosphate turnover in the sarcoplasmic merbranes. Biochem.. Soc. Spec. Publ. 4: 159-173.

Hastings, D.P , and Reynolds. J.A> 1979. Molecular weight of $\left(\mathrm{Na}^{+}, \mathrm{K}^{+}\right)$-ATPase from shark rectal gland. Biochem. 18: $817-821$.

Herbert, H. Jorgensen, P.L. Skriver, E. and Maunsbach. A.B. 1982. Crystalline patterns of membrane-bound $(\mathrm{Na}+\mathrm{K}+)$-ATPase. Biochim. Biophys. Acta 689: 571-5і4.

Hess, H.H., Lees, M.B., and Derr, J.E. 1978. A liniar Lowry-Folin assay for both water-soluble and sodium dodecyl sulfate-solubilized proteins. Anal. Biochem. 85: $295-300$. 
Hickman. D.D., and Frenkel. A.W. 1965. Observations on the structure of Rhodespirillum fubrum. J. Cell Biol. 25; $279-291:$

Higashi. T., Kalra, V.K., Lse. S.H., Brogin. E.. and Brodie. A.F. 1975. Energy-transducing membrane-bound coupling factor ATPase from Mycobacterium phlei. I. Purification, homogenelty and properties. $J$ : Biol lhem. 250: $6541-6548$.

Hinkle. P.C., and McCarty, R.E. 1978. How celis make ATP. Sci. Aner. $238: 104-123 . \%$

Hobot. J.A. Carlemalm, E., Vilizgerr, W., and Kéllenberger, E. 1984. Periplasmic gel: now concept resulting form the reinvestigation of bacterial bell envedope ultrastructure by new methods. J. Bactariol. 160: $143-152$

Hodges. T.K. 1976. ATPases associated with membranes of $\because$ plant cells. In Encyclopedia of Plant Pbysielogy. New Series, vol. 2, Parts A, B. Berlin, HeidelberB, N.Y. Springer Verlag. 2A: 260-283. 
Hodgkin. A.L., and Keynes, R.D. 1955. Active transport of cations in glant axons from Sepla and Lelige. J.'Physiol. (London) 128: 28-60.

Hokin, L.E., Dahl, J.L., Deupree, J.D., Dixon, J.F.. Hackney, J.F., and Perdue, F. 1973. Studies on the characterization of sodium-potassium transport adenosine triphosphatase. X. Purification of the enzyme from the rectal glan of Squaias acanthas. J. Biol. Chem. 248 ? $2593-2605$.

Huberman, M.., and Salton. M.R.J. 1979. Purification and properties of the latent Fl-ATPase of Micrececcus lysedeikticas. Biochim. Biophys. Acta 547: 230-240.

Hylemon, P. B., Wells, J.S., Kreig, N.R.; and Jannasch. H.W. 1973. The genus spirillum: A taxonomic study. Int. J. Syst. Bacteriol. 23: 340-380.

Inouye, M. 1979. Bacterial euter membranes. John Wiley and Sons, Inc., N,Y.

Inouye. M., and Yee, M.E. 1972. Specific Ptoval of proteins from the envelope of Escherichia celi by protease treatments. J. Bacteriol. 112: 585-592. 
Ishida, M., and Mizushima, S. 1969. Mombrano ATPase of Bacillus megaterium. I. Properties of membrane ATPase and its solublized form. J'Biochem. (Tokyo) 66: 33-43.

Ishikawa. S. 1970. Properties of an oxidative phosphorylation system reconstituted from coupling tactors in Micrococcus lysodeikticus. J. Biochem. (Tokyo) B?: $297-312$.

Ishikawa. S., and Lehninger. A.L. i962. Keconstitution of oxidative phosphorylation in preparations irom Micrococcus Iysodeikticus. J. Biol. Chem. 237: 2401-2408.

Jilka, R.L., Martonosi, A.N., and Tillack, T.W. 1975 Effect of the purified $\left[\mathrm{Mg}^{2+}+\mathrm{Ca}^{2}+\right]$-activated ATPase of sarcoplasmic reticulum upon the passive $\mathrm{Ca}^{2}$ + permeability and ultrastructure of phospholipid vesicles. J. Biol. C. 250:7511-7524.

Josephson. L., and Cantely. L.C. 1977. Isolation of a potent (Na-K)ATPase inhibitor from striated muscle. Biochem. for. $4572-4.578$. 
Johansson, B.C., Baltscheffsky, M. . Baltscheffsky, H. . Baccarini-Melandri, A., and Melandr1, M. 1973.

Purification and properties of a coupling factor (Ca*-dependent adenosine triphosphatase) from Rhodespirilium rubrum. Eur. J. Biochem. 40: 109-117

Johansson, B.C., and Baltscheffsky, M. 1975. On subunit composition of the coupling factor (ATPase) from Rhodesplriflum rubrum. FEBS Lett. 53: 221-224.

Johansson, K.-E., and Hjerten. S. 1974. Localization of the Tween20-soluble membrane proteins of Acheleplasma Laidlawii by crossed immunoelectrophoresis. J. Mol. Biol. 86: $341-348$.

Johansson, K, -E, and Wroblewski, H. 1978. Crossed immunoelectrophoresis in the presence of Tween 20 or sodium deoxycholate of purified membrane proteins from Acholeplasma laldlawil. J. Bacteriol. 136: 324-330.

Johnson, R.C., Walsh, M.P., Ely, B., and'Shapiro, L. 1979. Flagellar hook and basal complex of Caulebacter crescentus.'J. Bacteriol. 138: 984-989.

Jones, C.W. . and Redfern, E.R. 1967. The cytochrome system of Azet bacter yinelandij. Biochim. Biaphys. Acta 143 : 340-353. 
Kagawa, Y.. and Racker, E. 1966. Partial resolution of the enzymes catalysing oxidative phosphorylation. IX.

Reconstruction of oligomycin-sensitive adenosine triphosphatase. J. Biol. Chem. 241: 2467-2474.

$<$

Kagawa, Y., Sone, N., Yoshida, M. Hirita, H., and Okamoto, H. 1976. Proton translocating ATPase of a - thermophilic bacterium. Morphology, subunits and chemical composition. J. Biochem. (Tokyo) 8Q: 141-151.

Kalra, V.K., Lee, S., Ritz, C.J., and Brodie, A.F. 1975. Purification and properties of membrnae-bound coupling factor-latent ATPase from Mrcobacterium phlei. J. Supramolecular. Struct. 3: 231-241.

Kaneda, T. 1977. Fatty acids of the genus Bacillus. An example of branched-chain preference. Bacteriol. Rev. 41: $391-418$.

Kanazawa, H.. Mabuchi, K., Kayanó, T., Noumi, T. Sekiya. T., and Futai, M. 1981. Nucleotide siquence of the genes for Fo components of the proton-translocating ATPase from Escherichia coli: prediction of the primary structure of Fo subunits. Biochem. Biophys. Regs. Commun. 1e3: 613-620. 
Randier. 0 . i982. Cell wall structures and their phylogenetic implication. Zebtralblatt fur Bakteriologie. Mikrobiologie und Hygiene, I Abteilung, Originale - C-Algmeine, Angewandte und Okologische. Mikrobiologie 3 : $149-160$.

Karmali. M.A., and Skirrow. M.B. 1984. Taxonomy of the genus campylobacter. In Campylobacter Infection in Man and Animals (Butzler. J.P.. ed.). CRC Press Inc.. Boca Raton. F1. PP. $1-20$.

Keeler, R.F., Ritchie, A.E., Bryner, J.H., and Elmore, J. 1966. The preparation and characterization of celi walls and the preparation of flagella in Yibrio fetus. J. Gen. Microbiol. $43: 439-454$.

Kellenberger. E., and Ryter. A. 1958. Cell wall and cytoplasmic membrane of Escherichia soli. J. Biophys.) Biochem. 4: 323-325.

Kellermann, $0 .$, and Szmelcman, S. 1980. Active transport of maltose in Escherichia coli K12. Involvement of a "periplasmic" binding protein. Eur. J. Biochem. 47: $139-149$. 
Kinne Saffran, E., and Kinne. R. 1974, Prosence of a bicarbonate stimulated ATPase in brush border microvillus. membranes of propimal tubules. Proc. Soc. Exp. Med. 146: $751-753$.

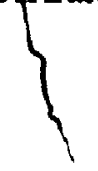

Knowles. A.F., and Penesky, H.S. 1972. The subunit structure of beer heart mitochondrial atpase: physical and chemical properties of isolated subunits. J. Biol. Chem. 247: $6624-6630$.

Kobayashi, H., and Ankaku, Y. 1972. Membrane-bound adenosine triphosphatase of Escherichia celi. I. Partial purification and properties. J. Biochem. '(Tokyo) I1: $387-399$.

Koval, S.F., and Jarrel, K.F. 1986. Ultrastructure and biochemistry of the cell wall of Methanececcus veltae. J. Bactelol.169: 1298-1306.

Laemmli, U.K. 1970. Cleavage of structural proteins during the assembly of the head of bacteriophage T4. Nature (London) 227: 680-685.

Lechevalier, M.P. 1977. Lipids in bacterial taxonomy -- a taxonomists view. CRC Critic. Rev. Microbiol. s: 109-210. 
Lee, S., Cohen, N.S., and Brodie, A.F. 1976. Restoration of axidative phosphorylation by purified N,N'-dicyclohexylcarbodimide-sensitive latent adenosine triphosphatase from Mycobacterium phlei. Proc. Natl. Acad. Sci. U.S.A. I3: 3050-3053.

Leonard, E.P., and Provenza, D.V. 1972. Comparative study of the various methods for the ultrastructural localization of alkaline phosphatase activity. Histochemie. $30: 1-12$.

Lien. S., and Racker, E. 1971. Preparation and assay of chloroplast coupling factor CF1. Meth. Enzymol. 23: $547-555$.

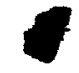

Lim, S-H., and Salton, M.R.J. 1981. Fi-ATPase of Micrececcus lysedeikticus is not a glycoprotein. Biochem. Biophys. Acta 638: 275-281.

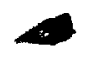

Livne, A., and Racker, E. 1969. Partial resolution of the enzymes catalysing photophosphorylation. V. Interaction of coupling factor 1 from chloroplasts with ribonucleic acid and lipids. J. Biol. Chem. 244: 1332-1338.

Lo. T.C.8. 1979. The molecular mechanisms of substrate transport in Gram-negative bacteria. Can. J. Biochpon. 57: $289-330$. 
Lucke. F.K., and Klemme, J.H. 1976. Coupling factor adenosine-5' 'riphosphatase from Rhedespirillum rubrum. simple and rapid procedure for its purification. 2 . Naturforsh. 31: 272-279.

Luderitz, O., Westphal, O., Staub, A.M., and Nikaido, H. 1971. Isolation and chemlcal and immunological characterization of bacterial lipopolysaccharıdes. In Chapt. 4. Microbiol Toxins, vol. 4. Bacterial Endotoxins (Weinbaum, G., Kadis, S., and Ajl, S.J., eds, Acad. Press. N.Y., and London. Pp. 145-233.

MacFarland. B.H., and Inesi, G. 1971. Solubilization of sarcoplasmic reticulum with triton $x-100$. Arch. Biochem. Biophỳs. 145: 456-464.

MacGregor, C.H., Bishop, C.W., and Blech, J.E. 1979. Localization of proteolytic activity in the outer membrane of Escherichia celi. J. Bacteriol: 13i: 574-583.

Mack Ivey, D., and Ljungdahl, L.G. 1986. Purification and characterization of the Fi-ATPase from clestridiuim

thermeaceticum. J. Bactqriol. 165: 252-257. 
MacLennan, D.H., Seeman, P., Iles, G.H., and YoP, C.C. 1971. Membrane formation by the adenosine triphosphatase. of sarcoplasmic reticulum. J. Biol. Chem. 246; 2702-2710.

Macnab, R.M. 1979. How do flagella propel bacteria. Trends Biochem. Sci. (Pers. ed.) 4: N10-N13.

Málpartida, F., and Serrano, R. 1980. Purification of the yeast plasma membrane ATPase solubilized with a novel zwlterionic detergent. FEBS Lett. 111: 69-72. :

Malpartida, F., and Serrano, Ri 1981. Phosphorylated intermediate of the ATPase form the Plasma membrane of yeast. Eur. J. Biochem. 1.16: 413-417.

Manning, P.A., and Reeves, P. 1976. Outer membrane of Escherichia celi K12: Differentiation of protein $3 A$ and 3B on acrylamide gels and further charactierization of con(tolG)'mutants. J. Bacteriol. 127: 1070-10979.

Manning, P.A., Puspurs, A., and Reeves, P. 1976. Outer membrane of Escherichia seli K12. Isolation of mutants Fith altered protein $3 \mathrm{~A}$ by using host range mutants of bacteriophage K3. J. Bacteriol. 127: 1080-10k4, 
Matsubara, H., Hase, T., Hashimoto, T., and Tagawa, K. 1981. Amino acid sequences of an intrinsic inhibitor of mitochondrial ATPase from yeast. J. Biochem. 90: $1159-1165$.

-

Maunsbach, A.B., Skriver, E., Herbert, H., and Jorgensen. P.L. 1983. Electron Microscope analysis of two dimensional crystals of membrane bodnd Na,K-ATPase. Curr. topics Memb. Trans. 19: 123-126.

Mclarty, R.E. 1979. Interaction between nucleotides and coupling factor 1 in chloroplasts. Trends Biochem. Jci. 4 : $28-30$.

McCarty, R.E., and Racker, E. 1966. Effect of a coupling factor and its antiserum on photophosphorylation and hydrogen ion transport. Brookhaven symp. biol. 19: $202-214$

McCoy, E.C., Wiltberger, H.A., and Winter, A.J. 1976. Major outer membrane protein of Camplyobacter fetus: Physical and immunological characterization. Infect. Immun. 13: 1258-1265. 
Mitchell, P. 1981. Biochemical mechanism of proton-motivated phosphorylation in FoFl agenosinp triphosphatase moleculo. In Mitochondria and micorsomes (Lee, C.P., and schatz, G...eds.). Addison Wesley Pub. co., Inc., Reading, Mass. pp. 427-457.

$$
\because
$$

Moller, J.V., Andersen, J.P., and le Maire, M.-1982. The sarcoplasmic retivulum Ca2+-ATPase. Molecular Cellular Biochem. 42: 83-107.

Mollinedo, F. Larraga, v. Coll, F.J., and Munoz, E. . 1980. Role of the subunits of the energy transducing adenosine triphosphatase from Micrecoceus Lysodeikticis membranes, studied by protelolytic digestion and immunological approaches. Biochem. J. 186: 113-723.

Mollinedo: F., Larraga, V., and Munoz, E. 1983. Comparative aspects of the attachment of Fl-ATPase to Micrececcus lysedeikticus membranes: Role of ions and subunits. J. Gen. Migrobioi. 129: 3465-3472.

Monteil, H. and Serrahina-Zieger, M. .1978., Les ATPase Bacteriennes: Proprietes moleculaires et fonctions. Bull. Inst. Pasteur 76: 207-246. 
Munkres, M., and Wachtel, A. 1967. Histochemical

localization of phosphatases in Mrcoplasma galdisepticum.

J. Bacteriol. 93: 1096-1103.

Munoz, E. 1982. Polymorphism and conformational dynamics of $F_{1}$-ATPase from bacterial membranes. A modell far nogulaiton of these enzymes on the basis of molecular plasticity. Biochum. Biophys. Acta 650: 233-265.

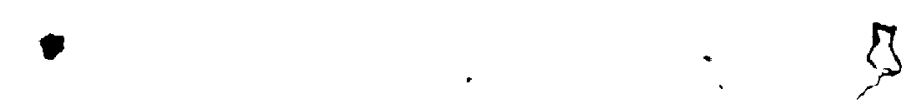

Muncz, E., Froer, J.H. Ellar, D.J., and-Saiton, M.R.J. 1968 Membrane associated ATPase activity from Micrococcus Lysodeifticixs. Biochim. Biophys. Acta 150: $331-533$.

Munoz, E., Salton, M.R.J., Ng, M.H., and Schor.M.T. 1969. Membrane adenosine triphosphațase of Micrececcus. lysedeikticus'. Purification, properties of the "soluble" enzyme and properties of the membrane-bound enzyme. Eur. $\ddot{j}$; Biochem. 7 : 490-501.

Murray, R.G.E. 1957. Direct evidence" for, a cytoplasicic membrane in sectioned bacteria. Can.J. Microbiol. $\mathfrak{3}$ : $531-532$.

Murray, R.G.E., and Birch-Andersen, A. 1963. Spectalized structure, in the region of the fiagella tuft in spirillum seppens. Can- J. Microbiol. 9: 393-401. 
Murray, R.G.E., Steed, P., and Elson, H.E. 1965. The location of the mucopeptide in sections of the cell wall of Escherichra celi and other Gram-negative bacteria. Can. J. Microbiol. 11: 547-560.

Nakae, T. 1976a, Identification of the outer membrane protein of Escherichia sel) that produces transmembrane channels in reconstituted vesicle membranes. Biochem Biaphys. Res. Commun. 71: 877-884.

Nakae. T. 1976b. Uuter membrane of Salmenella: I solation of protein complex that produces transmembrane channels. -J. Biol. Chem. 251: 2176-2178,

Nelson, N. 1976. Structure and function of chloroplas ATPase. Biochim. Biophys. Acta 456: 314-338.

Nelson. N.. Kanner, B.I., and Gutnick, D.L. 1974. Purification and properties of $\mathrm{Mg}^{2}+\mathrm{Ca}^{2}+$ adenosine triphosphatase from Escherichia coli. Proc. Natl. Acad. Sci. U.S.A. II: $2720-2724$.

Nieuwenhuisr F.J.R.M., van der Drift, J.A.M., Voot, A.B.. and Van Dam, K. 1974. Evidence for a natyrally occuring. ATPase-inhibitor in Escherichia selt. Blochim: Blophys. Acta 368: $461-463$. 
Ng, L.K., Sherburne, R., Taglor, D.E., and Stiles, M.E> 1985. Morphological forms and viablity df Camprlobacter species studied by electron microscopy. J. Bacteriol. 164: $338-343$.

O'Farrell. P.H. 1975 High resolution two-dimensional ebectrophoresis of proteins. J. Biol. Chem. 250: $4007-4021$.

Ogg, J.E. 1962 - Studies on the coccoid form of ovine Vibrie fetus. I. Cultural and serologic investigations Amer. J. Vet. Res. 23: 354-358.

Ohkuma, S., Moriyam, Y., and Takano, T. 1982.

Identification and characterization of a proton pump on . lysosomes byluorescein isthiocyanate-dextran fluorescence. Proc. Nat1. Acad. Sci. U.S.A. 79: 2758-2762.

O'Neal, 5.G., Rhoads, D.B., and Racker, E. 1979.' Vanadate inhibition of sarcoplasmic reticulum $\mathrm{Ca}^{2}+-\mathrm{ATPase}$ and other Atpases. Blochem.. Biophys. Res. Commun. 89: 845-850.

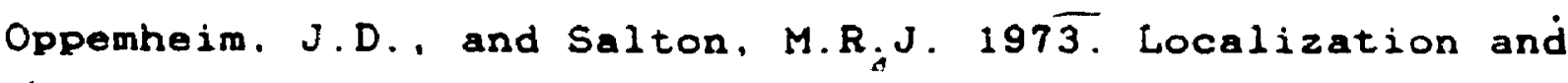
distribution of Microceccus lysodeikticus membrane ATPase determined by ferritin laboling. Biochim. Biophy.s. Acta $298: 297-322$. 
Osborn. M.J. 1968. Structure and biosynthesis of the bacterial cell wall. Anna. Rev. Biochem. 38: 501-538. ,

Osborn. M.J., Gander, J.E.. Parisi. E.. and Carson. J. 1972. Mechanism of assembly of the outer membrane of Salmonella typhimurium. Isolation and characterization of cytoplasmic and outer membrane. J. Biol. Chem. 247: $3962-3972$.

Usborn. M.J.. and Wu, H.C.P. 1980. Proteins of the outer membrane of Gram-negative bacterı. Annu. Rev. Microbiol. 34: $369-442$.

Otero-Vilardebo, L.R., Lane, N.,. and Godman, G.C. 1963. Demonstration of mitochondrial ATPase activity in formalin-fixed colonic epithelial cells. J. Cell Biol. 19: $647-652$.

Owen, P., and Salton, M.R.J. 1975. Antigenic and enzymatic architecture of Micrococaus lysodeikticus membranes. established by crossed, immunoelectrophoresis.. Proc. Natl. Acad. Sci. U.S.A. . 72: $3711-3715$.

Owen, P., and Salton, M.R.J. 1977, Membrane asymmetry and expression of cell surface antigens of Mlcrececaus lysodelkticus established by crossed immunoelectrophoresis. J. Bacteriol. 132: 974-985. 
Owen. P., and Smyth. C.I 1977. Enzyme analysis by quantitative immunoelectrophores 35 . In Immunochomistry of 1 inolectrophoresis. Enzymes and Their Antibodies (Salton, M.R.J.. ed.), John Willey, N.Y. PP. 147-202.

Pandit-Hovenkamp. H. G. 1967. Microbial phosphorylating preparations: Azotobacter. Meth. Enzymo1. 10: 152-157.

Federsen. P.L. 1975. Interaction of homogeneous mitoohonarial ATFase Irom rat liyer with adenine nucleotides and inorganic phosphate. J. Supramolecul: struct. 3: 222-230.

Pedersen, P.L., Amzel, L.M., Soper, J.W., Cirtron, N. . and Hullithen J. 1978. Structure, function, and regulation of the mitochondrial adenosine-triphosphatase complex of rat-1iver. In Energy Conservation in Biological Membranes (Schater. G., and Klingeberg. M. eds.), Springer-Verlag, Berlin. pp: 159-194.

Pedersen. P.L., Hullihen.J., and Wehrle, J.P. 1981. Proton adenosine triphosphatase complex of rat.liver. The effect of trypsin on the $F_{1}$ and Fo moleties of the enzyme. J. Biol. Chem. 256: 1362-1369. 
Peneisky, H.S. 1974. Mitochondrial and chloroplasts ATPases. In The Enzymes (Boyer, P.D., ed.), Acad. Press, N.Y. and London. Vol. 10. PP. 375-394.

Penefsky, H.S. 1979, Mitochondrial ATPase. Adv. Enzymol. 49: $223-280$.

Penersky, H.S., and Warner, R. 1965. Partial resolution of the enzymes catalysing oxidative phosphorylation. VI studies on the mechanism of cold-inactivation of mitochondrial adenosine triphosphatase. J. Biol. Chem. 240: $4694-4702$.

Phelps, D.C., Nordenbrand, K. . Nelson: B.D., and Ernster. L. 1975. Inhibition of purified mitochondrial ATPase (F1) by bathophenanthroline and. relief of the inhibition by uncouplers. Biochem. Biophys. Res. Commun. 63: 1005-1012.

Pinchot. G.B. 1953. Phosphorylation coupled to electron transport in cell-free extracts of Alealizenes faecalis J. Biol. Chem. 205: 65-74.

Pinchot, G.B. 1957. A polynucleotide coenzyme of oxidative phosphorylation. J. biol.' Chem. 229: 1-9. 
Pinchot, G.B., and Racker, E. 1995. Phósphorus Metabolisim (McElroy, W.D., and Glass, B., eds.), Bailtomore, John • Hopkıns Univ. Press. Vol. 1, p. 366.

Racker, E. 1967. Resolution and reconstitution of the Inner mitochondrial membrane. Red. Proc. 26: 1335-1340.

Reed. D.W., and Raveed. D. 1972. Some properties of the ATPase irom chromatophores of Rhodepseudemonas spheroides and its structural relationship to the bacteriochlorophyll proteins. Biochim. Biophys. Acta 283: 79-91.

Remsen, C.C., Watson, S.W., Waterbury, J.B., and Truper, H.B. 1968. Fine structure of Ectothierhodespira mobilis Pelsh. J. Bacteriol. 25: 2374-2392.

Reynolds. E.S. 1963. The use of lead citrate at high $\mathrm{pH}$ as an electron opaque stain in electron microscopy. J. Cell Biol. 17: 208-213.

Riebeling, V., and Jungermann, K. 1976. Properties and function of Clostridial membrane ATPase. Biochim. Biophys. Acta. 430 : $434-444$.

Risi, S., Hockel, M., Hulla, F.i.., and Dose, K. 1977. Fi-ATPase from Micrococaus sp. ATCC 398 . Purification by 
ion-exchange chromatography and further characterization. (auto)proteolysis and dissociative effects. Eur. J. Biochem. 81: 103-109.

Ritchie, A.E., Keller, R.F., and Bryner, J.J. 1966.

Anatomical features of Vibrie fetus: electron microscopy survey. J. Gen. Microbiol: 43: 427-438.

Ritz, C., and Brodie, A.F. 1977. Effects of trypsin

treatment on the structure and function of solubilized coupling factor-latent ATPase of Mycobacterlum phter.

Biochem. Biophys. Res. Cómmun. 75: 933-939.

Ritz-Gold, C., and Brodie, A.F. 1979. Limited proteolysis of coupling factor-latent ATPase from vycobacterium phlei. Effects of different enzymes and modifying agents. Biochim. Biophys. Acta 547: 18-26.

Ritz-Gold, C.J., Gold, C.M., and Brodie, A.F. 1979 Pryptic proteolysis of coupling factor-latent ATPase from Mrcobacterium phlei. Theoretical modeling of structure-function relationships. Biochim. Biophys. Acts 547: $1-17$.

Rogers, H.J. 1983. Bacterial Cell structure. In Aspects 
of Microbiology, vol. 6 (Cole, J.A.m Knowles, C.J., and Schiessinger, D., eds., Aser. Soc. Microbiol. Publ.. Washington. D.C.

Rogers, H.J., Perkins. H.R., and Ward, J.B. 1980. Microbzal cell walls and membranes. Chapman and Hall. London, N.Y.

Rosenbusch. J.P. 1974. Characterization of the major envelope protein from Escherichla coli: Regular arrangement of the peptidoglycan and unusual dodecyl sulphate bindrng. J. Biol. Chem. 249: 8019-8029.

Roth. J. 1982. The protein A-gold (PAG) technique.

Qualitative and quantitative approach for antigen localization on thin sections. In Techniques in Immunocytochemistry, Vol. 1 (Bullock, G.R., and Petrusz, P., eds.), Acad. Press. N.Y., and London. PP. 107-133.

Roth, J., Bendayn, M., Carlamalm, E., Billiger, W., and. Garavito, R.M. 1981. Enhancement of structural preservation ay immunocytochenical staining in low. temperature embedịed pancgeatic tissue. J. Histochem. cytochem. 29: 663-671. 
Rottem, S., and Razin, S. 1967. Electrophoretic patterns of membrane proteins of Mrceplasma. J. Bacteriol. 24: $359-363$.

Ryter: A. : and Piechaud, M. 1963. Etude au microscope electronique de quelqueis souches de Meraxella. Ann. Inst. Past. 105: 1071 .

Sabatine, D.. Golman. D. Sabbin, E. Sherman, J.. Morimoto. T., Kreibich, G., and Adesnik: M. 1981 Mechanisms for the incorporation of proteins in membranes and organelles. J. Cell Biol. 92: 1-22.

Salton. M.R.J. 1953. Studies of the bacterial cell wall. IV. The composition of the walls of some Gram-positive and Gram-negative bacteria. Biochim. Biophys. Acta io: $512-523$.

Salton. M.R.J. 1971. The bacterial membrane. In Biomembranes I (Manson, L.A., ed.), Plenum, N.Y. Pp. 1-65.

Salton, M.R.J. 1974. Membrane associated enzymes in bacteria. In Advances in Microbial Physiology II. (Rose. A.H., and Tempest, D.W. eds. I, Pp.213-283.

Salton, M.R.J. 1978. Structure and function of bacterial - plasma membranes. Symp. Soc. Gen. Microbiol. 28: 201-223. 
Salton, M.R.J., and Owen, P. 1976. Bacterial membrane structure. Annu. Rev. Microbiol. 30: 451-482.

Salton, M.R.J., and Schor, M.T. 1972. Subunit structures and properties of two forms of ATPase released from Micrecoccus lysodeikticus ATPase from membranes extracted with n-butanol. Biochem. Biophys. Res. Compun. 49: $350-357$

Saltọn. M.K.J., and Schor, M.T. 1974. Release and purification of Microceccus lysodeikticus ATPase from membranes extracted with n-butanol. Biochim: biophys. Acta 345: $74=82$.

Salton, M.R.J., Freer, J.H., and Ellar, D.J. 1968.

- Electron transport components localized in a lipid-depleted sheet isolated from Microceccus Lysedeikticus membranes by deoxylate extraction. Biochem. Biophys. Res. Communo 33: 909-915.

Salton, M.R.J., Schor, M.T., and Ng, M.H. 1972. Internal localization of Micrococcus lysedelkticus membrane ATPase. by iodination with $125 \mathrm{I}$. Biochim. Biophys. Acta 290: 408-413.

Sarkadi, B. 1980. Active calcium transport in human cells. Blochim: Blophys. Acta 604: 159-190. 
Schieiter, K.H., and Kandler. O. 1972. Poptidoglycan types of bacterial cel! walls and their taxonomic implications. Bacteriol. Rev, 36: 407-477.<smiles>CCCC</smiles>

SchneklifH.P., and Abrams, A. 1970: Membrane adenosine triphosphate from strettococcús faecalis. Preparation and homogeneity. J. Biol. Chem. 245: 1115-1121:

Schnebli; H.P., Vatter, A.E., and Abrams, A. 1970.

Membrane adenosine triphophate from streptococcus taecalis. Molecular weight, subuint structure and anino acid composition. J. Biol. Chem. 345: 1122-1127.

Senior, A.E., Fayle, D.R.H., Downie, J.A., Gibson, F.. and Cox. G.B. 1979. Properties of membranes from mutant strains of Escherichia coli in which the beta subunit of the adenosine triphophatase fs abnamal. Biochem. $\mathrm{J}: 180$ $111-118$

,Serrahina-Zieger, M., and Monteil. H. 1978. Membrane ATPase of Bacillus subtilis. I. Purification and properties. Biochim. Biophys. Acta 502: 445-457.

Serrano;, R:- 198.4. Flasma membrane ATPase of fungi and plants as a novel type of proton pump. Curir. Topics Coll Regul. 23: 87-126. 
Silverman, M.R., and Simon, M.I. 1972. Flagellar assembly mutants in Escherichia seli. J. Bäteriol. 112: 986-993

Silverman: M.R., and Simon. M.I. 1977. Bacterial flagella. Annu. Rev. Microbiol. 31: 397-419.

Skriver, E., Maunsbach, A.'B., and Jorgensen, P.L. 1981.' Formation of two-dimensional crystals in pure membrane-bound $\mathrm{Na}^{+}, \mathrm{K}^{+}-\mathrm{ATP} \mathrm{I} \mathrm{se}$. FEBS Lett. 131: 219-222.

Smibert. R.M. 1965. Vibrio fetus var. intestinalis isolated from fecal and intestinal contents of clinically normal sheor: biochemical and cultural characteristics of microaerophilic vibrios isolated from the intestinal contents of sheep. Amer. J. Vet. Res. 26: 320-327.

Smibert, R.M. 1978. The genus Campypobacter. Annu. Re?. Microbiol. 32: $673-709$. $^{\circ}$

Smibert, R:M., 4984. Genus Campylobacter Sebald and Veron. 1963. 907. In Bergy's Manual of Systematic Bacteriologx. Vol, 1, (Krieg, N.R., and Holt, J.G., eds.), Williams and Wilkins, Baltimore and London. Pp.111-118.

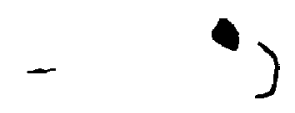

Smyth: C.J., Friedman-Kien, A.E., and Salton, M.R.J. 1976. Antigenic analysis. of Nedsseria genorrboead by crossed immunoelectrophoresis. Infect. Immun. 13: 1273-1288. 
Smyth, C.J., Seigel. J.. Salton, M.R.J.. and Uwen: P. 1978. Immunochemical analysis of inner and outer membranes of Escherichia celi by crossed innumoelectrophoresis. J. Bacteriol. 133: 306-319.

Spenning, J.G., Strysh. A.. Price, A.H.,. Helander, H.F.. and Sachs, G. 1973. Properties of ATPase of gastric mucosa. V. Preparation of membranes and mitochondria by zonal centritugation. Biochim. Biophys. Acta, 311 : 545-564.

Steck. T.L.. and. Fox. U.F: 1972. Membrane proteins. In Membrane Molecular Biology, Fox, C.F., and Keith. A.D.,

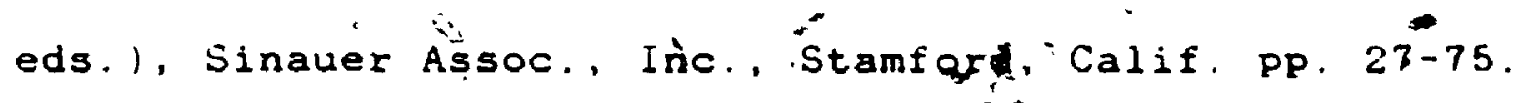

Steven, A.C., tenHeggeler, B., Mulier, R., Kistler, J.. and Rosenbusch. J.P. 1977. UItrastructure at a periodic proteln layer on the outer membrane of Escherdchia coli. J. Celibiol .72: 292-301.

Stioechenium, W., and Rowen, R. 1967. A morphological study of Halobactecium halobitm and its lysis in medis of lowsalt concentration. J. Cell Biol. 31: 365-393.

Strotmann; H., Hesse, H., and Edelmann, K. 1973.

Quantitative determination of compling factor $\mathrm{CF}_{1}$ of chloroplasts. Biochim. Biophys. Acta $\frac{314: 202-210 .}{4}$ 
Sone, N., Yoshida, M., Hirata, H., and Kagawa, Y. 1975.

Purification and properties of a dicyclohoxylcarbodiimido senstive ATPase from a thermophilic bacteriup. J. Biol:

Chem. 250: 7917-7923..

Stone, D.K., Xiad-Song, X., and Racker, E. 1983. An ATP-driven protọn pump in clathrin-coated vesicles. J, Biol: Chem. 258: 4059-4062.

- Sun.' I.L., 'Fhelps, D.C., and Crape, F.L. 1975. Llpoprilic chelator inhibition of Escherichia coli"membrane-bound ATPase activity and prevention of inhibition by uncouplers. FEBS Lett. 54: 253-258.

Terasaki, Y. F970. Some observations on the life history of Spiridlup serpens:- Bull. Suzugamine Women's Coll. Nat... Sci. $15: 9-17$.

Thompsn. B.G., and Murray, R.G.E. 1982. The fenestrated -peptidoglycan layer of Deinecojecus radiedurans. "Can. J. Microbiol. 28: $522-525$.

\section{$\boldsymbol{s}$}

T\$khonova, G.V., Biketov, S.F., Kasho,..V.N. . Kozolv, I.A. .* Mileihorshaya, E.I.: Ostrovskit, D.N. ; 'Simakova, I.M., and Skulacher..V.P. 1983. Poculiarities of the subuntt composition of -ATPase from the anaerobic bacterium iretobacillus saser: Blokhimiya 48 : 1348-1353. 
Tonomura, $Y .$, and Inoue, A. 1974. The substructure $0 f$. myosin and the reaction mechanism of its aderiosine triphosphatase. Molecul. Cell ochen: 5: 127-143.

Towbin, H.. Staehelin, T., and Gordon. J. 1979.

Electrophoretic transfer of proteins from polyacrylamide gels to nitrocellulose sheets. Proc. Natl. Acad. Sci. U.S:A. $76: 5340-5354$.

Uchida, E. Ohsum 1 ... and Anraku, Y. 1985 . Furstication and properties of $\mathrm{H}^{+}-t r a n s l o c a t i n g . \mathrm{Mg}^{2+-a d e n o s i n e .}$ triphophatase from vacuolar membranes of saccharomyces cerevisiae. J. Biol. Chem. 260: 1090-1095.

Urbar, C., and Salton; M.R.J. 1983a. Antigenic expression of the Microceccus lysodeikticus (luteus). $\dot{F}_{1}$-ATPase as determined by immunoelectrophoretic anabysis. FEMS Microbiol. Lett. 19: 9?-10.1.

Urban, C., and Salton, M.R.J. 1983b. Immunochemical analysis of Microceccus lysodeiktiaus (Luteus) Fi-ATPaso and its subunits. Biochim. Biophys. Acfa 724: 230-240.

Vaituzis, 2. 1973. Localization of adenosine triphosphatase activity, in motile bacteria. Can. J. Microbiol. 19: 1265-1267. 
Vambutas, V.K., and Racker, E. 1965. Partial resolution of the enzymes catalyzing photophosphorylation. I.

Stimulation of photophosphorylation by a preparation, of a latent $\mathrm{Ca}^{++-d e p e n d e n t}$ adenosine triphosphatase from chloroplasts. J. Biol. Chem. 240: 2660-2667.

Van de Stadt, R.J., Van Dam, K., and Slater, E.C. 1974.

Interaction of aurovertin with sub-mitochondrial páatrcles. deficient in ATPase inhibitor. Bjochım. Biophys. Acta 347: 224-239.

Van Iterson, W. 1961. Some features of a remarkable or manelle in Bacillus subtilis. J. Biophys. Eiornem. Cytol. 2: 183-192.

Voelz. H. 1964. Sites of adenosine triphosphatase activity in bacteria. J. Bacteriol. 88: 1196-1198.

Vogel, G., Schairer, H.U., and Steinhart, R. 1978.

Complementation in yitro of mutant and wild-type ATPase of Escherichia seli using isolated subunits. Eur. J. Biochem. 87: $155-160$.

-Vogel. G., and Steinhart, R. 1976. ATPase of Escherichia celi: Purification, G/Hsociation, and reconstitution of the active complex from the isolated subunits.. Biochem. 15: 208-210 
Wakabayashi, T., Kubota, M., Yoshida, M., and Kagawa, Y. 1977. Structure of ATPase (coupling factor $\left.T F_{1}\right)^{\circ}$ from a thermophilic bacterium. J. Mol. Biol. 127: 515-519.

Ward. J.B. 1981. Teichoic and teichuronic acids:

- Biosynthesis: assembly, and locatzon. Microbiol. Rev. 45: $211-243$.

- Heidel. W. 1950. In Viruses (Delbruck. M. ed.). - Lailiornza Rst. Tech. Pp. 119-121.

Weiss. R.L. 1974. Subunit cell wall of Sulfolobus acidecaldarius. J. Bacteriol. 118: 275-284.

-

Wetzel, \$.K., Spicer. S.S., Dvorak, H.F., and Heppel, L.A. 1970. Detochemical localization certain phosphatases in Escherichia celi. J. Bacteriol...iú4: 529-542.

White. D.A., Lennerz, W.J. and Schnaitman, C.A. 1972. Distribution of lipids in the wall and, cytoplasmic membrane subfraction of the cell envelope of escherichid cell. J. Bacţeriol. 109: 686-690.

Woese, L.R. 1987. Bacterial. Evolution. Microbiol, Bov. 51' $221-271$. 
Yoshida, M., Sone, N., Hirata, H., and Kagawa, Y. 1975. A highly stable adenosine triphosphatase from a thermophilic. bacterium; purification, properties and reconstitution. J. Biol. Chem. 250: 7910-7916.

, 